\title{
ESTIMATING REAERATION COEFFICIENTS FOR LOW-SLOPE STREAMS IN MASSACHUSETTS AND NEW YORK, 1985-88
}

By Gene W. Parker and Leslie A. DeSimone

\section{U.S. GEOLOGICAL SURVEY}

Water-Resources Investigations Report 91-4188

Prepared in cooperation with the

MASSACHUSETTS DEPARTMENT OF ENVIRONMENTAL PROTECTION, DIVISION OF WATER POLLUTION CONTROL

and the

NEW YORK STATE DEPARTMENT OF ENVIRONMENTAL CONSERVATION, BUREAU OF MONITORING AND ASSESSMENT

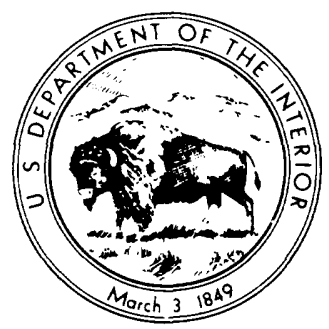

Marlborough, Massachusetts 1992 


\section{U.S. DEPARTMENT OF THE INTERIOR}

MANUEL LUJAN, JR., Secretary

U.S. GEOLOGICAL SURVEY

Dallas L. Peck, Director

For additional information, write to:

\section{District Chief}

Massachusetts - Rhode Island District

Water Resources Division

U.S. Geological Survey

28 Lord Rd., Suite 280

Marlborough, MA 01752
Copies of this report can be purchased from:

U.S. Geological Survey

Books and Open-File Reports Section

Box 25425, Federal Center

Denver, CO 80225 


\section{CONTENTS}

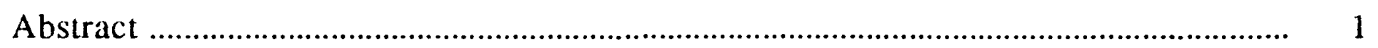

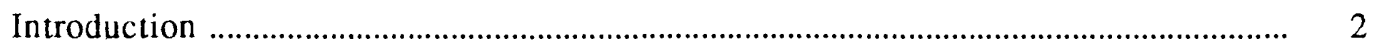

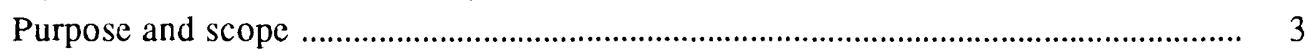

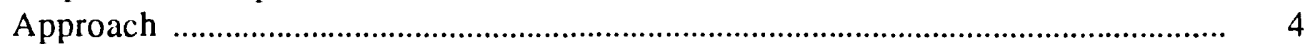

Acknowledgments ................................................................................................. 4

Theory and methodology of estimating reacration coefficients .................................. 11

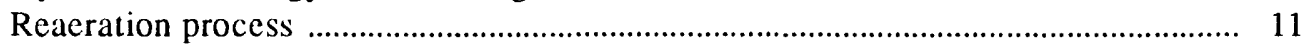

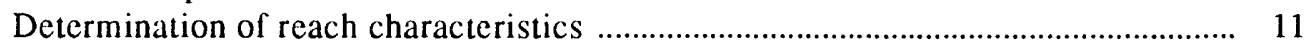

Determination of time-of-travel characteristics ................................................... 12

Measurement of reacration coefficients ................................................................ 12

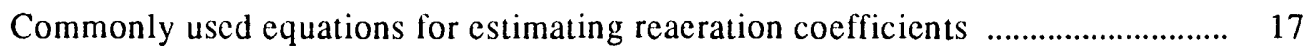

Empirical equation for estimating reaeration coefficients ......................................... 18

Limitations of new empirical equation ................................................................ 26

Error analysis of new empirical equation ............................................................... 26

Application of empirical equation to a reach ............................................................... 26

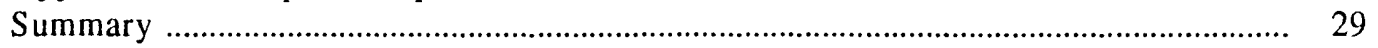

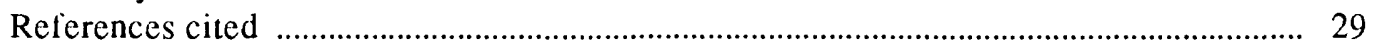

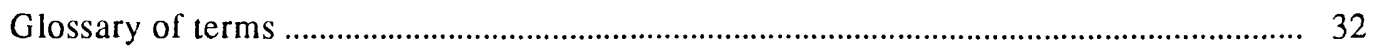

Appendix 1. Reach location and description ....................................................... A-1

Appendix 2. Reach characteristics, time-of-travel characteristics, and measured reaeration coefficients from 42 stream tracer studies .............................. B-1

Appendix 3. Results from error analyses of equations 10 through 30

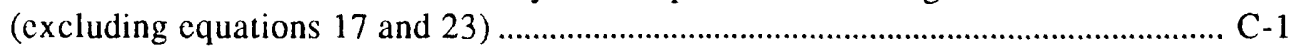

Appendix 4. Results from error analysis of new empirical equation........................ D-1

\section{ILLUSTRATIONS}

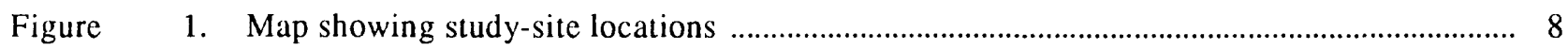

2. Graph showing relation of measured and cstimated reaeration coefficients

from 29 tracer studies conducted on low-slope streams in

Massachusetts and New York, 1985-88 ..................................................................... 25

3. Map showing location of stream reach on Normans Kill near Westmere, 


\section{TABLES}

Page

Table 1. Methods used to determine reach characteristics from 42 tracer studies conducted on low-slope streams in Massachusetts and New York ...

2. Tracer studies conducted on streams in Massachuseus and New York, 1985-88 ................... 9

3. Minimum, median, mean, and maximum values of reach characteristics and measured reaeration coefficients from 29 tracer studies conducted on naturally-flowing low-slope streams

4. Minimum, median, and maximum values of reach characteristics and measured reacration coefficients from cight tracer studies conducted on naturally-flowing low-slope streams with a single impoundment.

5. Minimum, median, mean, and maximum values of reach characteristics and measured reaeration coefficients from five tracer studics conducted on naturally-flowing high-slope streams

6. Statistical summary of crror analyses of equations 10 through 30 (excluding equations 17 and 23 )

7. Weighted correlation coefficient matrix used in the reaeration-coefficient regression analysis

8. Statistical summary of error analysis for new empirical equation. 


\section{CONVERSION FACTORS, VERTICAL DATUM, AND ABBREVIATED WATER-QUALITY UNITS}

\begin{tabular}{lcl}
\hline Multiply & By & To obtain \\
\hline & Length & \\
foot $(\mathrm{ft})$ & 0.3048 & meter \\
mile (mi) & 1.609 & kilometer \\
& Flow & \\
foot per second $(\mathrm{f} t / \mathrm{s})$ & 0.3048 & meter per second \\
cubic foot per second $\left(\mathrm{ft}^{3} / \mathrm{s}\right)$ & 0.02832 & cubic meter per second \\
& Temperature &
\end{tabular}

To convert degree Celsius $\left({ }^{\circ} \mathrm{C}\right)$ to degree Fahrenheit $\left({ }^{\circ} \mathrm{F}\right)$, use the following formula:

$$
1.8 \times{ }^{\circ} \mathrm{C}+32={ }^{\circ} \mathrm{F} \text {. }
$$

Sea level: In this report, "sea level" refers to the National Geodetic Vertical Datum of 1929--a geodetic datum derived from a general adjustment of the first-order level nets of the United States and Canada, formerly called Sea Level Datum of 1929.

Milligrams per liter ( $\mathrm{mg} / \mathrm{L}$ ) is a unit expressing the concentration of a chemical constituent in solution as weight (milligrams) of solute per unit volume (liter) of water: $1 \mathrm{mg} / \mathrm{L}$ equals 1,000 micrograms per liter $(\mu \mathrm{g} / \mathrm{L})$. 


\title{
Empirical Equation for Estimating Reaeration Coefficients for Low-Slope Streams in Massachusetts and New York, 1985-88
}

\author{
By Gene W. Parker and Leslie A. DeSimone
}

\section{ABSTRACT}

Multiple-regression techniques were used to develop the following empirical equation for estimating reaeration coefficients for low-slope streams in Massachusetts and New York: $K_{2}=3.83 \mathrm{MBAS}^{-0.41}$ $S L^{0.20} D^{-0.76}$, where $K_{2}$ is the depth-averaged reaeration coefficient at the standard temperature of 20 degrees Celsius, in base e units per day; MBAS is the concentration of methylene-blue-active substances, in milligrams per liter; SL is the water-surface slope, in foot per foot; and $D$ is the mean depth, in feet. Multiple-regression analyses of measured reaeration coefficients and 14 hydraulic, physical, and water-quality characteristics of reaches from 29 tracer studies conducted on low-slope (water-surface slopes of less than 0.002 foot per foot) streams in Massachusetts and New York were used to develop the equation. Reaeration coefficients measured in 1985-88 for 29 stream tracer studies ranged from 0.16 to 10.99 base e units per day. Concentration of methylene-blue-active substances is significant because it is thought to be an indicator of the surfactants concentration, which could change the surface tension at the water-air interface.

Reaeration coefficients and reach characteristics were determined from 29 stream tracer studies conducted on reaches in Massachusetts and New York. Hydraulic characteristics of reaches determined from each tracer study were (1) water-surface slope, (2) mean stream velocity, (3) average windspeed at the closest National Oceanic and Atmospheric Administration weather station, and (4) resultant wind velocity paral- lel to the channel azimuth and corrected for the mean sheltering angle. Physical characteristics of reaches determined from each tracer study were (1) mean depth, (2) mean width, (3) channel azimuth, (4) channel elevation, and (5) mean sheltering angle. Waterquality characteristics of reaches determined from each tracer study were (1) color, (2) concentration of total organic carbon, (3) concentration of methyleneblue-active substances, (4) specific conductance, and (5) concentration of suspended solids.

An error analysis technique was used to compare the measured reaeration coefficients with reaeration coefficients obtained from 19 commonly used equations. Equations were ranked in each of three groupings of 42 stream tracer studies according to their accuracy in terms of absolute average error and standard deviation of residuals. The three groupings are (1) unweighted, measured reaeration coefficients for 29 tracer studies conducted on streams having water surface slopes less than 0.002 foot per foot; (2) unweighted, measured reaeration coefficients for five tracer studies conducted on streams having water surface slopes greater than 0.002 foot per foot; and (3) unweighted, measured reaeration coefficients for eight tracer studies conducted on streams having water surface slopes less than 0.002 foot per foot and having a single, small impoundment. The error analysis indicates that the Parkhurst and Pomeroy (1972) equation has the best ranking, with an average error of 65 percent and a standard deviation of residuals of 2.23 for 29 low-slope stream studies. The error analysis indicates that the Smoot (1987) equation has the best ranking, with an average error of 40 percent and a standard deviation of residuals of 2.20 for the eight low-slope streams with single impoundment studies. 
No single equation ranked in the top three for both average absolute error and standard deviation of residuals when considering the five tracer studies on streams with a water surface slope greater than 0.002 foot per foot.

The proposed equation improves the accuracy of estimating reaeration coefficients and can be used for predicting attenuation of volatile compounds released into streams. An example of application of the equation for predicting volatilization of a spilled contaminant from a low-slope stream is given.

\section{INTRODUCTION}

Reacration coefficients are used in stream water-quality models to estimate dissolved-oxygen concentrations in reaches affected by organic loadings. State water-pollution-control agencies, such as the Massachusetts Department of Environmental Protection, Division of Water Pollution Control, and the New York State Department of Environmental Conservation, Bureau of Monitoring and Assessment, rely on stream dissolved-oxygen models to help make decisions concerning the maintenance of stream water-quality standards set by each State in conjunction with the U.S. Environmental Protection Agency (USEPA).

The self-cleaning capacity of a stream depends on the initial dissolved-oxygen concentration and on the capacity of the stream to replace oxygen removed by the oxidation of organic wastes. All major sources of and demands for dissolved oxygen are considered in modcling dissolved-oxygen concentrations in streams. Dissolved-oxygen sources include oxygen production by periphyton and phytoplankton, and reaeration through the water surface. Dissolved-oxygen demands include respiration of aquatic organisms, decay, and other biochemical demands. Dissolved-oxygen concentrations also can change because of dispersion. All of these processes can be measured or estimated.

Three-fourths of the large population centers in Massachusetts discharge treated sewage into low-slope (water-surface slopes of less than $0.002 \mathrm{ft} / \mathrm{ft}$, or approximately $10 \mathrm{ft} / \mathrm{mi}$ ) streams. Low-slope streams in Massachusetts and New York typically are characterized by forested, scrub/shrub, and (or) emergent wetland areas; slow water velocities; and large longitudinal-dispersion coefficients. Reaeration is an important source of oxygen in streams and an important component of the dissolved-oxygen balance of streams. However, because of cost considerations, reaeration coefficients rarely are measured and commonly are estimated from equations.

Before the 1970s, the two methods most commonly used to measure reaeration coefficients were the dissolved-oxygen-balance method and the disturbedequilibrium method. Both methods consist of a summation of the rate of change in a stream's dissolved-oxygen content, the rate of oxygen production, the rate of oxygen utilization, and the rate of reaeration. The summation is solved for the unknown reaeration coefficient by trial and error. The methods differ in the use of natural stream-dissolved-oxygen content or artificially-reduced stream-dissolved-oxygen content. In the disturbed-equilibrium method, initial stream-dissolved-oxygen content is artificially reduced by the addition of sodium sulfite to a stream. In addition to being costly and time consuming, both methods are indirect determinations of reacration coefficients that may be no more accurate than reaeration coefficients calculated from many estimating equations (Bennett and Rathbun, 1972).

The most recently accepted method used to measure reaeration coefficients is the gas-tracer method. In the gas-tracer method, reaeration coefficients are measured by the mass-transfer rate of a tracer gas. At a standard temperature, the mass-transfer rate of a tracer gas is directly proportional to the transfer rate of oxygen (reacration). Constants associated with the direct relation of mass-transfer rates can be determined in the laboratory. Therefore, an organic gas, such as propane, can be used as a tracer to directly measure the transfer rate of oxygen. Recent advances in the gastracer method, such as the steady-state propane-gastracer method (Yotsukura and others, 1983, 1984; Kilpatrick and others, 1987), provide an economical, accurate, and reproducible method of determining reaeration coefficients along a reach. A further advantage of the gas-tracer method is that the use of a tracer not naturally present in the environment eliminates the necessity of accounting for other sources and demands. In contrast, the dissolved-oxygen balance and disturbed-equilibrium methods require accounting for photosynthetic oxygen production and for respiration of the suspended and attached aquatic plants, in addition to measuring dissolved oxygen (Rathbun and others, 1978; Rainwater and Holley, 1983).

In recent years, the need to evaluate the residence times in and transfer rates from surface-water systems of volatile-organic contaminants has increased substantially with the passage of many Federal and State environmental laws. Most volatile-organic compounds have transfer rates that are first-order pro- 
cesses like the reacration process. Rathbun and Tai (1981) and Chiou and others (1983) reported that these volatilization coefficients can be estimated in relation to the reacration coefficient using oxygen as a reference material. The determination of accurate reaeration coefficients has application beyond understanding oxygen transfer alone. It can be used to better understand the fate of other volatile gases within a stream system.

Predicting the effectiveness of waste-water practices in meeting the stringent water-quality standards imposed for streams in Massachusetts and New York require the use of accurate reaeration coefficients. However, the expense of measuring reacration coefficients in nature, even when the steady-state propanegas-tracer method is used, makes direct measurements for all reaches impractical. The U.S. Geological Survey (USGS), in cooperation with the Massachusetts Department of Environmental Protection, Division of Water Pollution Control, developed the following regionalized regression equation (Parker and Gay, 1987):

$$
\mathrm{K}_{2}=252.2 \mathrm{D}^{-0.76} \mathrm{~V}^{0.355} \mathrm{SL}^{0.438}
$$

where
$\mathrm{K}_{2}$ is the reacration coefficient, in base $\mathrm{e}$ units per day;
$\mathrm{D}$ is the mean depth, in $\mathrm{ft}$;
$\mathrm{V}$ is the mean stream velocity, in $\mathrm{ft} / \mathrm{s}$; and
$\mathrm{SL}$ is the water surface slope, in $\mathrm{ft} / \mathrm{ft}$.

The Parker and Gay (1987) equation relates reaeration coefficients to hydraulic and physical characteristics of reaches. The equation, which was developed from a data base of 30 stream tracer studies, has a correlation coefficient of 0.85 and a standard error of estimate of 37.5 percent. The 30 stream tracer studies were conducted during periods of litule or no wind at the water surface. Water-surface slopes were greater than $0.002 \mathrm{ft} / \mathrm{ft}$ for 20 of the stream tracer studies and at or less than $0.002 \mathrm{ft} / \mathrm{ft}$ for 10 of the stream tracer studies. For the 20 stream tracer studies conducted on streams having water-surface slopes greater than $0.002 \mathrm{ft} / \mathrm{ft}$, the Parker and Gay (1987) equation has an average absolute error of 27 percent. For the 10 stream tracer studies conducted on streams having water-surface slopes at or less than $0.002 \mathrm{ft} / \mathrm{ft}$, the equation has an average-absolute error of 177 percent. The large average-absolute error indicates that reach characteristics not included in the Parker and Gay (1987) equation are affecting the gas-transfer process in low-slope streams.
Reacration and mass-transfer rates of gases are controlled by the processes that maintain an imbalance of gas concentration across the water-air interface (Yotsukura and others, 1983). Wind shear at the water surface is one of these processes. Wind shear can be affected by the sheltering angle of the basin caused by the vegetation along the riverbank and the hills surrounding the stream. Wind shear also can be affected by the azimuth of the basin in relation to the direction and speed of the prevailing winds. In the northeastern United States, wind shear at the water surface is reduced by the general north-south orientation of most river valleys and by the large percentage of stream channels bordered by forest.

In high-slope streams, the transport of gas away from or to the water-air interface is controlled primarily by turbulence in the water column and, to a lesser extent, by wind shear at the water surface. Turbulence in the water column can be affected by changes in hydraulic and physical characteristics of reaches, such as watersurface slope, mean stream velocity, mean depth, and mean width.

In low-slope streams, reacration can be affected by less dynamic processes, such as changes in water quality. Water quality in a stream may be indicated by color as an indicator of humic and fulvic acid concentration, TOC (total organic carbon) concentration as an indicator of organic concentration, concentration of MBAS (methylene-blue-active substances) as an indicator of surfactants concentrations, specific conductance as an indicator of dissolved-solids concentration, and suspended-solids concentration as an indicator of suspended-inorganic concentration (Bennell and Rathbun, 1972). For streams having low-water-surface slopes and low-mean-stream velocities, turbulence in the water column is less pronounced, and the transport of gas across the water-air interface is controlled by the less dynamic processes.

\section{Purpose and Scope}

This report describes the equation development for estimating reacration coefficients for low-slope streams using weighted, multiple, stepwise regression techniques. (P-STAT, Inc., 1989, p. 42.13-42.14). The new equation was developed by analysis of $14 \mathrm{mea}-$ sured physical, hydraulic, and water-quality characteristics of reaches (table 1). Twenty-nine stream tracer studies were conducted on 24 reaches of 18 naturally flowing low-slope streams in Massachusetts and New York (fig. 1 and table 2). The reaches represented 
most types of low-slope stream channels commonly occurring in Massachusetts and New York.

This report also describes the results of an error analysis of 19 commonly used reaeration-coefficient estimating equations. The error analysis was conducted on three groupings of $\mathbf{4 2}$ stream-tracer studies from 33 reaches of 22 streams in Massachusetts and New York (fig. 1). Twenty-nine of the 42 stream-tracer studies were conducted on naturally flowing low-slope reaches. Five of the 42 studies were conducted on reaches with slopes of more than $0.002 \mathrm{ft} / \mathrm{ft}$ (highslope) and eight studies were performed on reaches having low slopes with a single, small impoundment. All impoundments had water residence times of less than 7 days. The results from the additional stream tracer studies were used to test the accuracy of the 19 equations for streams with reach characteristics close to but outside the range of reach characteristics determined for the 29 low-slope stream tracer studies. All stream tracer studies were conducted during mediumand low-flow periods from May 1985 through October 1988 .

\section{Approach}

Based upon previous reacration work in Massachusetts streams (Parker and Gay, 1987) and review of reaeration literature, 14 hydraulic, physical, and water-quality characteristics of reaches (table 1) were selected to be correlated with the measured reaeration coefficient. The reach characteristics were determined from 29 stream tracer studies (combined time of travel and reaeration) conducted on 24 reaches on 18 streams (fig. 1). The 24 reaches were selected for study on the basis of geographic distribution, consistency of reach characteristics within each reach, and accessibility. Reach locations and descriptions are given in Appendix 1 at the end of this report. When possible, adjacent reaches of a stream were studied concurrently, and studies were repeated on the same reach at different discharge rates. Hydraulic, physical, and water-quality characteristics of reaches were determined from each tracer study, and water-quality samples were collected for reach characteristics requiring laboratory analysis. Windspeed and wind direction data were obtained from reports published by the National Oceanic and Atmospheric Administration (1985; 1986a, b; $1987 \mathrm{a}, \mathrm{b}, \mathrm{c}, \mathrm{d} ; 1988 \mathrm{a}, \mathrm{b}, \mathrm{c}, \mathrm{d})$.

All tracer study data were analyzed to determine timeof-travel characteristics and initial propane-gas desorption coefficients as outlined by Yotsukura and others (1983) and Kilpatrick and others (1987). Final reacration cocfficients were determined using superposition techniques (Yotsukura and others, 1983; Kilpatrick and others, 1987). The measurement error for each tracer study was estimated using the technique outlined by Yotsukura and others (1983).

The new empirical equation for estimating reacration coefficients was developed from measured reacration coefficients and corresponding reach characteristics determined from the 29 tracer studies conducted on low-slope streams. Step-wise multiple-regression analyses (P-STAT, Inc., 1989, p. 42.13-42.14) were conducted to statistically relate weighted-measured reaeration coefficients to reach characteristics. Weights were determined from the estimated measurement error for each tracer study and from an estimated model error. Only reach characteristics significant at a 95-percent confidence level were retained.

Reaeration coefficients were estimated from the new empirical equation developed in this study and from 19 commonly used estimating equations. All equations were ranked in each of five groups of the 42 stream tracer studies according to the accuracy of their estimated reaeration coefficients. The equations were ranked for how well estimated reaeration coefficients compared with weighted and unweighted measured reaeration coefficients from all 42 stream tracer studies and with unweighted, measured reacration coefficients from three subgroups of the 42 stream-tracer studies. The three subgroups are the 29 studies conducted on streams having water-surface slopes of less than $0.002 \mathrm{ft} / \mathrm{ft}$; the five studies conducted on streams having water-surface slopes greater than $0.002 \mathrm{ft} / \mathrm{ft}$; and the eight studies conducted on streams having water-surface slopes of less than $0.002 \mathrm{ft} / \mathrm{ft}$ and having a single, small impoundment.

\section{Acknowledgments}

The authors thank the many persons and organizations who have given their time, information, and guidance to this study. Personnel from the Massachusetts Department of Environmental Protection, Division of Water Pollution Control, office in Westborough, Mass., and the New York State Department of Environmental Conservation, Bureau of Monitoring and Assessment, assisted in the selection of reaches and in the collection of all data and provided information available from previous dye-tracer studies. In addition, the authors are indebted to landowners and mu- 
Table 1.--Methods used to determine reach characteristics from 42 tracer studies conducted on low-slope streams in Massachusetts and New York

Reach characteristic

Description of determination methods

Water-surface slope (foot/foot)

Determined as the change in water-surface elevation over the reach divided by the reach length $(\mathrm{L})$. Water-surface elevation was determined by differential leveling from bench marks to the sampling sites. Reach lengths between sampling sites were measured from topographic maps.

Mean stream velocity (V)

(foot per second)

Average windspeed

(foot per second)

Resultant wind velocity parallel to channel azimuth and corrected for mean sheltering angle (foot per second)

Mean width (W) (foot)
Determined by dye tracer time-of-travel data by solving the equation:

$$
V=\frac{L}{\bar{T}},
$$

where $\mathrm{V}$ is the mean streamflow velocity, in feet per second;

$L$ is the reach length, in feet;

$\overline{\mathrm{T}}$ is the centroid traveltime of a slug-injected dyetracer response curve measured over a test reach [the slug injection method is explained in more detail by Hubbard and others (1982)];

Determined by averaging the daily average windspeed as reported by NOAA (National Oceanic and Atmospheric Administration) at the closest NOAA weather station (Boston, Massachusetts; Worcester, Massachusetts; Hartford, Connecticut; or Albany, New York) for the duration of each tracer study (National Oceanic and Atmospheric Administration, 1985; 1986a,b; 1987a,b,c,d; 1988a,b,c,d).

Determined in two steps. Initial wind velocity is reduced by multiplying the wind velocity component perpendicular to the channel azimuth by the sine of the sheltering angle. Next, the component of half of this adjusted wind velocity parallel to the channel azimuth is determined by the cosine of the smallest angle between the wind direction and the channel azimuth.

Determined by averaging widths at 10 to 30 evenly spaced locations along a reach. Widths were measured with a cloth tape or a calibrated optical rangefinder. 
Mean depth (D) (foot)

Channel azimuth (degree)

Channel elevation (foot)

Mean sheltering angle (degree)

Color (platinum-cobalt)

Total organic carbon concentration (milligram per liter)
Determined by solving the continuity equation:

$$
\mathrm{D}=\frac{\mathrm{Q}}{\mathrm{W} \mathrm{V}} \text {, }
$$

where $Q$ is the discharge determined by averaging measured discharge at each sampling site, in cubic feet per second. Discharge measurements were made using the methods outlined by Buchanan and Somes (1969) and confirmed using the dye-dilution-total-recovery method (Kilpatrick and Cobb, 1984).

Determined by measuring the angle formed by the reach from true north on topographic maps.

Determined as the average water-surface elevation between the sampling sites at each end of a reach. Watcr-surface elevation was determined by differential leveling from bench marks.

Determined by measuring the angle between wind barriers on both sides of the river in a vertical plane perpendicular to the direction of streamflow. The reported sheltering angle is the average of measurements made at 10 to 30 locations along a reach. Examples of wind barriers are trees and hills.

Measured in a water sample collected at the water-quality monitoring site during each study. Measured by comparison with calibrated colored glass disks according to the method outlined by Goerlitz and Brown (1972).

Measured in a water sample collected at the water-quality monitoring site for each study. The sample was analyzed according to the method outlined by Goerlitz and Brown (1972). 
Table 1.--Methods used to determine reach characteristics from 42 tracer studies conducted on low-slope streams in Massachusetts and New York--Continued

Reach characteristic

Description of determination methods

Concentration of methylene-blue-active substances (milligram per liter)

Specific conductance (SC) (microsiemen per centimeter at 25 degrees Celsius)

Suspended-solids concentration (SS) (milligram per liter)
Measured in a water sample collected at the water-quality monitoring site during each study. The sample was analyzed spectrophotometrically according to the method outlined by Goerlitz and Brown (1972). The water-quality monitoring site for each study usually was established at the downstream end of a reach or, for concurrent reaches, at the junction of the reaches. If a water-quality change was expected between reaches, water samples were collected for analysis at the end of each reach. For Massachusetts studics, analyses were made at the U.S. Geological Survey's Central Laboratory in Arvada, Colo. For New York studies, analyses were made at the New York State Department of Health, Wadsworth Center for Laboratories and Research.

Measured at the water-quality monitoring site for each study with a continuous recording monitor or a conductance meter. Supplemental measurements of specific conductance also were made at all tracer study sampling sites.

For Massachusetts studies, estimations were made by the equation:

$$
\mathrm{SS}=\mathrm{ROE}-(0.54 \mathrm{SC}+2.7)
$$

where ROE is the concentration of total dissolved solids, in milligrams per liter, as determined by cvaporation at 105 degrees Celsius. Water samples were collected at the water-quality monitoring site for each study and analyzed according to the method outlined by Skougstad and others (1979).

$(0.54 \mathrm{SC}+2.7)$ is an equation to estimate the dissolved-solids concentration, in milligrams per liter, as outlined by Delaney and Gay (1980). A review of the literature indicates that the constant for a specific conductance to dissolved solids relation can range from 0.53 to 0.60 for Massachusetts rivers. The relation used to reflect an average for the State was developed for the Merrimac River, a large New England river basin, and was thought to be more transferable than a relation developed for a smaller basin.

For New York studies, samples were collected at the waterquality monitoring site for each study and analyzed according to the method outlined by Skougstad and others (1979). 


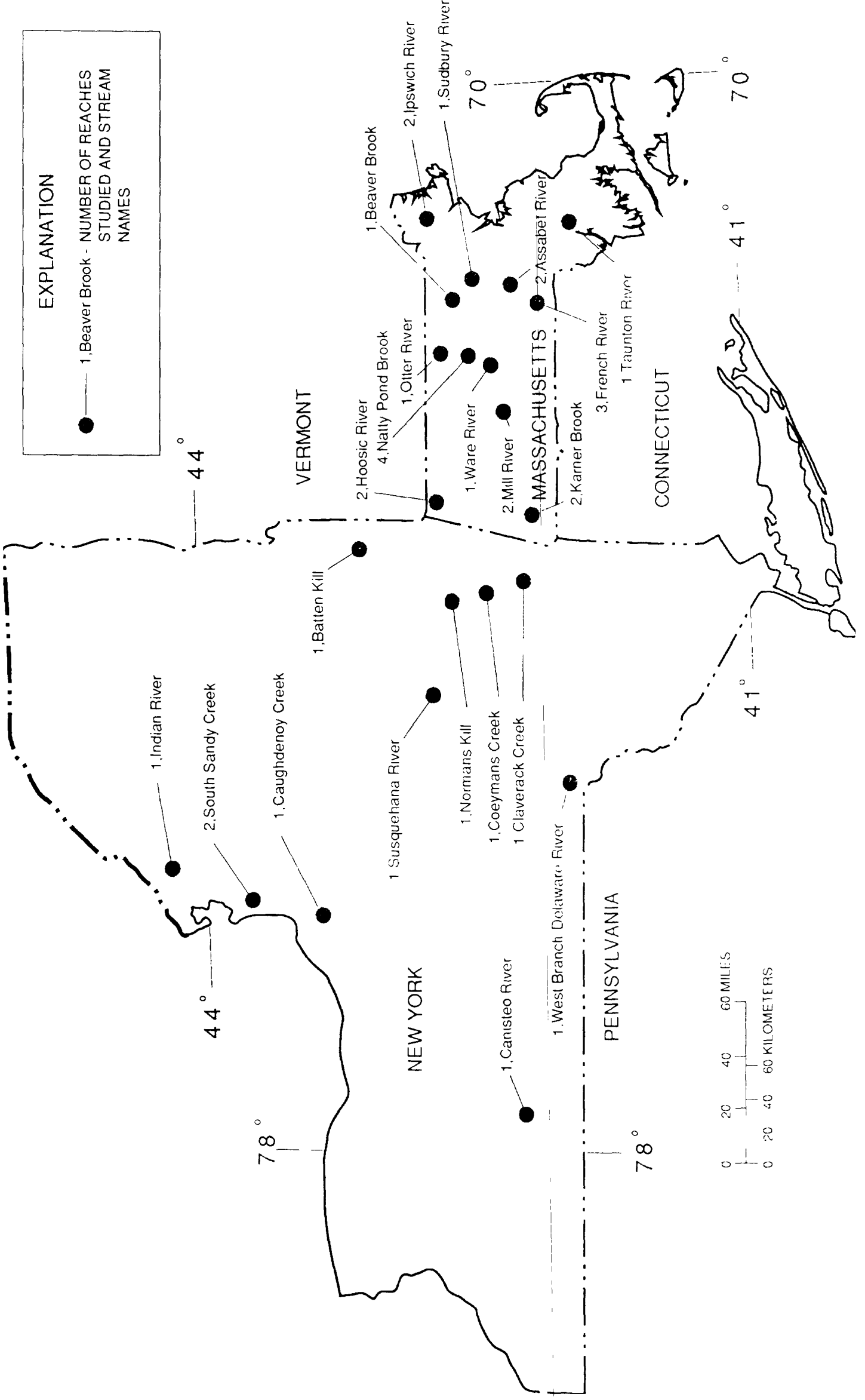

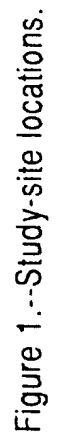




Stream name $\quad$ Reach $^{1} \quad \begin{aligned} & \text { Number of tracer } \\ & \text { studies conducted }\end{aligned} \quad$ Reach descriptor $^{2}$

Beaver Brook near Littleton, Mass.

Assabet River near Westborough, Mass.

Sudbury River near Wayland, Mass.

Ipswich River near Topsfield, Mass.

Taunton River near Bridgewater, Mass.

French River near Oxford, Mass.

Otler River near Gardner, Mass.

Mill River near Amherst, Mass.

Natty Pond Brook near Hubbardston, Mass.

Ware River near Barre, Mass.

Karner Brook at South Egremont, Mass.

Batten Kill near Greenwich, N.Y.

Hoosic River near Adams, Mass.

Normans Kill near Westmere, N.Y.

Coeymans Creek near Coeymans, N.Y.

Claverack Creek at Hudson, N.Y.

West Branch Delaware River near Deposit, N.Y.

\section{A}

A

B

A

A

B

A

A

B

C

A

A

B

A

B

C

D

A

A

B

A

A

B

A

A

A

A
1

3

1

1

1

1

2

2

1

2

1

1

1

1

1

2

1

1

1

1

1

3

2

1

1

1

1
Low-slope stream

Low-slope stream

Low-slope stream

Low-slope stream

Low-slope stream Impounded stream

Low-slope stream

Low-slope stream

Low-slope stream Impounded stream

High-slope stream

Low-slope stream Low-slope stream

Low-slope stream High-slope stream Low-slope stream Low-slope stream

Low-slope stream Low-slope stream Impounded stream

Impounded stream

High-slope stream Impounded stream

Low-slope stream

Low-slope stream

Impounded stream

Low-slope stream 
Table 2.--Tracer studies conducted on streams in Massachusetts and New York, 1985-88--Continued

$\begin{array}{lll}\text { Stream name } & \text { Reach }^{1} & \begin{array}{l}\text { Number of tracer } \\ \text { studies conducted }\end{array}\end{array}$

Susquehanna River at Phoenix Mills, N.Y.

A

1

Low-slope stream

Canisteo River at Hornell, N.Y.

A

1

Low-slope stream

Caughdenoy Creek near Caughdenoy, N.Y.

A

1

Low-slope stream

South Sandy Creek near Ellisburg, N.Y.

A

B

1

Low-slope stream

B

Indian River at Kelsey Bridge, N.Y.

A

1

Low-slope stream

A 11 Low-slope stream

${ }^{1} \mathrm{~A}$ is the first reach of a river; $\mathrm{B}$ is the second reach; $\mathrm{C}$ is the third reach; $\mathrm{D}$ is the fourth reach.

${ }^{2}$ Low-slope stream is a stream reach having a water-surface slope of less than 0.002 fool per fool; impounded stream is a stream reach having a single, small impoundment at the downstream end; high-slope stream is a stream reach having a water-surface slope greater than 0.002 foot per foot. 
nicipal officials who allowed day-and-night access through their property.

\section{THEORY AND METHODOLOGY OF ESTIMATING REAERATION COEFFICIENTS}

In order to evaluate the applicability of 19 commonlyused equations, the reach characteristics of 29 lowslope streams were measured. To further test these equations, reach characteristics at eight impounded low-slope streams, as well as five high-slope streams, were measured. Reacration coefficients were then computed from the commonly-used equations and compared with measured reaeration cocfficients at the high, low, and impounded stream systems.

If the results of the equations were not consistent in standard deviation of residuals and mean absolute error for all three groups of stream-tracer studies, other reach characteristics were deemed necessary to define the gas-transfer process in low-slope stream systems. The reaeration-process theory was reviewed in order to determine additional reach characteristics significant in low-energy environments.

\section{Reaeration Process}

Reaeration is oxygen transfer that occurs at the waterair interface. The rate of absorption of oxygen from air into water is controlled by the imbalance of oxygen concentration across the thin water-surface film. Rate of oxygen transfer across the water-air interface is a first-order process. Because vertical transfer of dissolved oxygen within the water column is rapid relative to transfer across the thin water-surface film, surface transfer of gases can be considered a firstorder process for the entire depth of the water column (Yotsukura and others, 1983). The surface transfer of gases is described by the following equation (Rathbun and others, 1978, p. 218, eq. 2):

$$
\frac{\mathrm{dC}}{\mathrm{dT}}= \pm \mathrm{KC}\left(\mathrm{C}_{\infty}-\mathrm{C}\right)
$$

where $\mathrm{C}$ is the dissolved-gas concentration

$\mathrm{C}_{\infty}$ is the gas concentration in the air above the water surface, in micrograms per liter;

$\mathrm{K}$ is the absorption or desorption coefficient, in units per time; and
$\mathrm{T}$ is time.

The plus sign indicates that a gas (like oxygen) is being absorbed into the water. A negative sign indicates desorption of a gas from the water. The depthaveraged absorption or desorption coefficient $(K)$ in equation 2 is directly proportional to the water-surface-film transfer coefficient (KL), as follows:

$$
\mathrm{KL}=\mathrm{KD} \text {, }
$$

where $\mathrm{KL}$ is the water-surface-film transfer coefficient; and

$D$ is the mean depth, in feet.

The absorption or desorption process is affected by wind shear at the water surface, turbulence in the water column, and water-quality characteristics. Wind shear disperses the gas that passes through the water-air interface and is affected by the sheltering angle along a reach, the azimuth of a reach relative to the prevailing winds, and the relative humidity of the air. Turbulence in the water column and at the stream surface enhances the dispersion process and is affected by changes in hydraulic- and physical-reach characteristics, such as water-surface slope, mean stream velocity, mean depth, and mean width. The absorption or desorption process also can be affected by high organic acids concentrations, surfactants concentrations, dissolved-solids concentrations, and suspended-solids concentrations that could affect surface tension, water density, gas solubility, or gas sorption to suspended particles.

\section{Determination of Reach Characteristics}

For each of the stream-tracer studies, the water-surface slope, mean stream velocity, average wind speed at the closest National Oceanic and Atmospheric Administration weather station, resultant wind velocity parallel to the channel azimuth as corrected for the mean sheltering angle, mean depth, mean width, channel azimuth, channel clevation, mean sheltering angle, color, TOC concentration, MBAS concentration, specific conductance, and suspended-solids concentration were determined. A description of determination methods for each reach characteristic is given in table 1. Values for the 14 reach characteristics listed as a reach characteristic in table 1 and measured reaeration coefficients from each of the tracer studies are given in Appendixes 2 and 3 at the end of this report. The minimum, median, mean, and maximum values of the 
14 reach characteristics, time-of-travel characteristics, and measured reaeration coefficients from the 29 lowslope stream-tracer studies, from the 8 low-slope tracer studies with a single impoundment and from the 5 high-slope tracer studies are given in tables 3,4 , and 5 , respectively.

\section{Determination of Time-of-Travel Characteristics}

The slug-injection dye-tracer method (Hubbard and others, 1982) was used to determine time-of-travel and hence mean stream velocity through a reach. Steady streamflow conditions are required. A known volume of a 20-percent fluorescent-dye solution was slug injected far enough upstream from the test reach to ensure complete lateral mixing of the dye cloud before it entered the reach. Water samples were collected at the upstream and downstream ends of the reach to determine changes in dye concentration with time. Watersample collection continued at each sampling site until the dye concentration dropped to 2 percent of the maximum concentration measured. Because dye samples do not require any special preservation, automatic samplers were used frequently for nighttime collection of water samples for dye-concentration analysis. For studies in Massachusetts, all water samples were retained at a constant temperature and reanalyzed in the USGS's office in Boston, Massachusetts. For studies in New York, only selected water samples were retained for reanalysis. Plots of changes in dye concentration over time since injection were used to define the dye-tracer response curve at each sampling site.

The mean stream velocity for a reach was determined with the following equation:

$$
V=\frac{L}{\left(\bar{T}_{d}-\bar{T}_{u}\right)},
$$

where $\mathrm{V}$ is the mean stream velocity, in feet per second;

$L$ is the reach length, in feet;

$\overline{\mathrm{T}}$ is the centroid traveltime of a slug-injected dye-tracer response curve measured at a sampling site;

d is a subscript that designates the downstream sampling site; and $\mathrm{u}$ is a subscript that designates the upstream sampling site.

The mean depth for a reach was determined with the continuity equation:

$$
\mathrm{D}=\frac{\mathrm{Q}}{\mathrm{WV}}
$$

where $\mathrm{Q}$ is the discharge determined by averaging measured discharge at each sampling site, in cubic feet per second; and

$\mathrm{W}$ is the mean width, in feet.

\section{Measurement of Reaeration Coefficients}

The steady-state propane-gas-tracer method described by Yotsukura and others $(1983,1984)$ and Kilpatrick and others (1987) directly measures the depth-averaged-desorption coefficient of propane gas. The steady-state method is a procedure involving the injection of both dye and gas tracers. The dye-tracer is injected as a slug. The gas-tracer is injected for a long duration, until steady-state conditions are reached throughout the test reach. Commercial-grade, propane-gas is the tracer injected through flat-plate porous-tile diffusers. Gas diffusers were placed on the river bottom within the middle 50 percent of the total streamflow for that cross section. The number of diffusers used in a study varied from two to eight depending on cross-section dimensions and flow conditions. The dye- and gas-tracer injections were made at identical upstream locations to ensure identical dispersion and dilution of both tracers, and to ensure complete lateral mixing of both tracers before they entered the reach.

The hydrocarbon gas, propane, was selected as a tracer because it is not naturally present in the environment, it is soluble in water, it is easily purchased locally, and the ratio of the transfer rates for propane gas and oxygen is known. Commercial-grade propane gas was injected from a 100-pound tank through a single-stage regulator and a carbon-dioxide- or air-calibrated flowmeter. A carbon-dioxide-calibrated flowmeter was used during all studies in Massachusetts to allow direct readings of the injection flow rate, inasmuch as the specific gravities of the propane and carbon-dioxide gases are nearly identical. An air-calibrated flowmeter was used during all studies in New York. Indicated airflow rates were corrected to propane-gas flow rates based on the ratio of their specific gravities. In 
Table 3.--Minimum, median, mean, and maximum values of reach characteristics and measured reaeration coefficients from 29 tracer studies conducted on naturally-flowing low-slope streams

Median

Mean

Maximum

Discharge (cubic foot per second) ${ }^{1}$

Water-surface slope (foot per foot)

Mean streamflow velocity (foot per second)

Average windspeed (foot per second)

Resultant wind velocity parallel to channel azimuth and corrected for mean sheltering angle (foot per second)

Mean depth (foot)

Mean width (foot)

Channel azimuth (degrees from true north)

Channel elevation (foot)

Mean sheltcring angle (degree)

Color (platinum-cobalt)

Total organic carbon concentration (milligram per liter)

Concentration of methylene-blue-active substances (milligram per liter)

Specific conductance (microseimen per centimeter at 25 degrees Celsius)

Suspended-solids concentration (milligram per liter)

Measured reaeration coefficient (base $\mathrm{e}$ unit per day)

$\begin{array}{lccc}1.6 & 14.0 & 32.6 & 315.8 \\ .00001 & .00023 & .00040 & .00170 \\ .01 & .20 & .23 & .62\end{array}$

7.3

13.0

13.4

21.7

.1

6.0

7.9

21.7

\section{.2}

19

6.0

13

25.0

5

1.4

.02

37

211

245

647

3

11

1.50
2.8

8.7

46

201

136.3

339.5

269

409

1,181

72.0

84.9

165.8

46

300

7.5

20

.07 .54

\footnotetext{
${ }^{1}$ Reach characteristic not used in multiple-regression analysis.
} 
Table 4.--Minimum, median, mean, and maximum values of reach characteristics and measured reaeration coefficients from eight tracer studies conducted on naturally-flowing low-slope streams with a single impoundment

\begin{tabular}{|c|c|c|c|c|}
\hline Reach characteristics & Minimum & Median & Mean & Maximum \\
\hline Discharge (cubic foot per second) & 2.1 & 34.9 & 49.7 & 187 \\
\hline Water-surface slope (foot per foot) & .00020 & .00040 & .00050 & .00092 \\
\hline $\begin{array}{l}\text { Mean streamflow velocity } \\
\text { (foot per second) }\end{array}$ & .01 & .22 & .27 & .66 \\
\hline Average windspeed (foot per second) & 10.1 & 13.8 & 14.1 & 20.7 \\
\hline $\begin{array}{l}\text { Resultant wind velocity } \\
\text { parallel to channel azimuth and corrected for } \\
\text { mean sheltering angle (foot per second) }\end{array}$ & .1 & 7.9 & 6.7 & 12.1 \\
\hline Mean depth (foot) & .7 & 2.5 & 3.4 & 9.0 \\
\hline Mean width (foot) & 29 & 64 & 93 & 246 \\
\hline $\begin{array}{l}\text { Channel azimuth (degrees from true } \\
\text { north) }\end{array}$ & 42 & 310 & 234 & 358 \\
\hline Channcl clevation & 49 & 469 & 453 & 728 \\
\hline Mean sheltering angle (degree) & 63 & 90 & 93 & 120 \\
\hline Color (platinum-cobalt) & 2 & 19 & 21 & 44 \\
\hline $\begin{array}{l}\text { Total organic carbon concentration } \\
\text { (milligram per liter) }\end{array}$ & 2.0 & 3.8 & 4.5 & 8.3 \\
\hline $\begin{array}{l}\text { Concentration of } \\
\text { methylenc-blue-active substances } \\
\text { (milligram per liter) }\end{array}$ & .02 & .03 & .03 & .07 \\
\hline $\begin{array}{l}\text { Specific conductance (microseimen } \\
\text { per centimeter at } 25 \text { degrees } \\
\text { Celsius) }\end{array}$ & 137 & 260 & 256 & 376 \\
\hline $\begin{array}{l}\text { Suspended-solids concentration } \\
\text { (milligram per liter) }\end{array}$ & 1 & 14 & 19 & 48 \\
\hline $\begin{array}{l}\text { Measured reaeration coefficient } \\
\text { (base e unit per day) }\end{array}$ & .21 & 1.20 & 2.80 & 9.20 \\
\hline
\end{tabular}


Table 5.--Minimum, median, mean, and maximum values of reach characteristics and measured reaeration coefficients from five tracer studies conducted on naturally-flowing high-slope streams

\begin{tabular}{|c|c|c|c|c|}
\hline Reach characteristics & Minimum & Median & Mean & Maximum \\
\hline Discharge (cubic foot per second) & 1.2 & 39.3 & 50.8 & 118.7 \\
\hline Water-surface slope (foot per foot) & .00325 & .00340 & .00390 & .00601 \\
\hline Mean streamflow velocity (foot per second) & .09 & .72 & .66 & 1.34 \\
\hline Average windspeed (foot per second) & 7.8 & 10.1 & 12.0 & 20.7 \\
\hline $\begin{array}{l}\text { Resultant wind velocity } \\
\text { parallel to channel azimuth and corrected for } \\
\text { mean sheltering angle (foot per second) }\end{array}$ & .7 & 1.7 & 3.9 & 14.1 \\
\hline Mean depth (foot) & 1.0 & 1.6 & 1.9 & 3.0 \\
\hline Mean width (foot) & 13 & 35 & 32 & 42 \\
\hline Channel azimuth (degrees from true north) & 3 & 7 & 65 & 302 \\
\hline Channel elevation (foot) & 725 & 725 & 794 & 909 \\
\hline Mean sheltering angle (degree) & 55 & 71 & 74 & 94 \\
\hline Color (platinum-cobalt) & 2 & 4 & 29 & 110 \\
\hline $\begin{array}{l}\text { Total organic carbon concentration } \\
\text { (milligram per liter) }\end{array}$ & 2.9 & 3.1 & 8.6 & 22.0 \\
\hline $\begin{array}{l}\text { Concentration of methylene-blue-active } \\
\text { substances (milligram per liter) }\end{array}$ & .03 & .03 & .04 & .09 \\
\hline $\begin{array}{l}\text { Specific conductance (microseimen } \\
\text { per centimeter at } 25 \text { degrees } \\
\text { Celsius) }\end{array}$ & 35 & 240 & 208 & 307 \\
\hline $\begin{array}{l}\text { Suspended-solids concentration } \\
\text { (milligram per liter) }\end{array}$ & 6 & 19 & 16 & 48 \\
\hline $\begin{array}{l}\text { Measured reaeration coefficient } \\
\text { (base e unit per day) }\end{array}$ & .8 & 6.7 & 6.3 & 10.2 \\
\hline
\end{tabular}


most studies, the gas-tracer injection was started 30 minutes to 2 hours prior to the dye-tracer injection to allow the gas-tracer injection rate to stabilize. In all studies, there were no significant interruptions in the gas-tracer injection, which ranged from 1 to 10 days.

During steady streamflow conditions, the long-duration steady-state gas-tracer injection allows gas samples to be collected at any time after the gas-concentration plateau is fully formed. The time at which the dye cloud has completely passed a sampling site corresponds to the time at which the gas-concentration has reached a constant plateau (Yotsukura and Kilpatrick, 1973; Kilpatrick and Cobb, 1984). After the dye cloud had passed, gas samples were collected at each sampling site from the same parcel of water as it traveled down along the reach. The time of travel of the centroid of the dye clouds was used to determine the time required for a parcel of water to pass between sampling sites in a reach. To determine propane-gas concentrations, water samples were collected every 30 minutes for a 2 -hour period with a volatile-gas sampler. To the extent possible, gas-sample collection at each sampling site was timed to occur during daylight and still be in the same water parcel. The gas-tracerinjection rate was maintained until after the water samples needed for propane-gas analysis were collected at all sampling sites. Water samples were preserved with $1 \mathrm{~mL}$ of a 37 -percent solution of formaldehyde. The propane-gas concentration in each sample was determined by gas chromatography at the USGS laboratory in Arvada, Colo., or Ocala, Fla., as outlined by Shultz and others (1976).

The propane-gas depth-averaged desorption coefficient was calculated as outlined by Yotsukura and others (1983) with the average gas-concentration plateau and dye-tracer response curves determined for each tracer study. When transverse mixing was not complete at a sampling site, the average gas-concentration plateau was determined with a mass-flow weighting of the gas concentrations measured at various points in the cross section. An initial estimate of the propane-gas depth-averaged desorption coefficient $\left(\mathrm{Kp}^{\prime}\right)$, in base e units per hour, was determined by the following equation:

$$
K p^{\prime}=\frac{1}{\bar{T}_{d}-\bar{T}_{u}} \ln \frac{\bar{C}_{u} Q_{u}}{\bar{C}_{d} Q_{d}},
$$

where $\overline{\mathrm{C}}$ is the average propane-gas plateau concentration, in $\mathrm{mg} / \mathrm{L}$ (micrograms per liter); and
$K p^{\prime}$ is the initial estimate of the propane-gas depth-averaged desorption coefficient, in base e units per hour.

$\mathrm{Kp}$ does not take into account the effects of longitudinal dispersion (Nobuhiro Yotsukura, U.S. Geological Survey, written commun., 1985). The actual propanegas depth-averaged desorption coefficient $(\mathrm{Kp})$, which does take into account longitudinal dispersion, was determined through iterative solution of the equation:

$$
\frac{\overline{\mathrm{C}}_{\mathrm{u}} \mathrm{Q}_{\mathrm{u}}}{\overline{\mathrm{C}}_{\mathrm{d}} \mathrm{Q}_{\mathrm{d}}}=\frac{\Sigma\left(\mathrm{C}_{\mathrm{c}, \mathrm{i}, \mathrm{u}} / \mathrm{A}_{\mathrm{u}}\right) \exp \left(-\mathrm{KpT}_{\mathrm{i}, \mathrm{u}}\right) \Delta \mathrm{T}_{\mathrm{i}, \mathrm{u}}}{\Sigma\left(\mathrm{C}_{\mathrm{c}, \mathrm{i}, \mathrm{d}} / \mathrm{A}_{\mathrm{d}}\right) \exp \left(-\mathrm{KpT}_{\mathrm{i}, \mathrm{d}}\right) \Delta \mathrm{T}_{\mathrm{i}, \mathrm{d}}},
$$

where $C_{c, i}$ is the dye concentration at the $i^{\text {th }}$ hour since the start of the injection, in micrograms per liter;

$A$ is the area under the dye-tracer response curve, in microgramshours per liter;

$\mathrm{Kp}$ is the actual propane-gas depthaveraged desorption coefficient, in base e units per hour; and

$T_{i}$ is the $i^{\text {th }}$ hour since the start of the injection.

The iterative process used $\mathrm{Kp}^{\prime}$ in equation 6 as an initial estimate of $\mathrm{Kp}$ in equation 7.

$\mathrm{Kp}$ was converted to the depth-averaged reaeration coefficient at the standard temperature of $20^{\circ} \mathrm{C}\left(\mathrm{K}_{2}\right)$ using the equation as represented by Kilpatrick and others (1987):

$$
\mathrm{K}_{2}=1.39 \mathrm{Kp} 1.024^{\left(20^{\circ}-\mathrm{t}\right)}(24),
$$

where $\mathrm{K}_{2}$ is the depth-averaged reaeration coefficient at the standard-temperature of $20^{\circ} \mathrm{C}$, in base e units per day;

$\mathrm{t}$ is the ambient water temperature, in ${ }^{\circ} \mathrm{C}$; and

24 is the constant to convert hours to days; and

1.39 is the ratio of the absorption rate for oxygen to the desorption rate for propane based on mixing-tank experiments (Rathbun and others, 1978).

The transfer of error from measurement to calculation is controlled by the non-dimensional number, 
$\mathrm{Kp}\left(\overline{\mathrm{T}}_{\mathrm{d}}-\overline{\mathrm{T}}_{\mathrm{u}}\right)$ (Yotsukura and others, 1983). The measurement error (E) for a reaeration study can be estimated by the following equation:

$$
E=\frac{E_{r}}{\operatorname{Kp}\left(\bar{T}_{d}-\bar{T}_{u}\right)},
$$

where $\mathrm{E}$ is the measurement error; and

$E_{r}$ is the relative error of gasconcentration measurements and discharge measurements.

The relative error of gas-concentration measurements and discharge measurements $\left(E_{r}\right)$ is estimated to be 10 percent for all studies.

\section{Commonly Used Equations For Estimating Reaeration Coefficients}

Physical and (or) hydraulic characteristics of a stream are used in most reaeration-coefficient estimating equations. With the exception of the Tsivoglou and Neal (1976) equation, 19 commonly used estimating equations require determination of mean stream velocity. The 19 commonly used reaeration coefficient estimating equations are as follow:

O'Connor and Dobbins (1958),

$$
\mathrm{K}_{2}=12.81 \frac{\mathrm{V}^{0.5}}{\mathrm{D}^{1.5}} ;
$$

Churchill and others (1962),

$$
\mathrm{K}_{2}=0.03453 \frac{\mathrm{V}^{2.695}}{\mathrm{D}^{3.085} \mathrm{SL}^{0.823}}
$$

Churchill and others (1962),

$$
\mathrm{K}_{2}=11.57 \frac{\mathrm{V}^{0.969}}{\mathrm{D}^{1.673}}
$$

Krenkel and Orlob (1963),

$$
\mathrm{K}_{2}=234.5 \frac{(\mathrm{V} \mathrm{SL})^{0.404}}{\mathrm{D}^{0.66}}
$$

Owens and others (1964),

$$
K_{2}=23.23 \frac{V^{0.73}}{D^{1.75}} ;
$$

Owens and others (1964),

$$
\mathrm{K}_{2}=21.73 \frac{\mathrm{V}^{0.67}}{\mathrm{D}^{1.85}}
$$

Dobbins (1965),

$K_{2}=116.6 \frac{1+F^{2}}{(0.9+F)^{1.5}} \frac{(\mathrm{V} \mathrm{SL})^{0.375}}{\mathrm{D}} \operatorname{coth}\left[\frac{4.10(\mathrm{~V} \mathrm{SL})^{0.125}}{(0.9+\mathrm{F})^{0.5}}\right]$

where coth is the hyperbolic cotangent of the angle, in radians; and

$F \quad$ is the Froude number, which is defined as the dimensionless ratio

$$
F=\frac{V}{(g D)^{0.5}}
$$

where $\mathrm{g}$ is the acceleration caused by gravity, in feet per second squared;

Langbein and Durum (1967),

$$
\mathrm{K}_{2}=7.61 \frac{\mathrm{V}}{\mathrm{D}^{1.33}} ;
$$

Isaac and Gaudy (1968),

$$
\mathrm{K}_{2}=8.62 \frac{\mathrm{V}}{\mathrm{D}^{1.50}} ;
$$

Cadwallader and McDonnell (1969),

$$
\mathrm{K}_{2}=336.8 \frac{(\mathrm{V} \mathrm{SL})^{0.5}}{\mathrm{D}} \text {; }
$$

Negulescu and Rojanski (1969),

$$
\mathrm{K}_{2}=10.91\left(\frac{\mathrm{V}}{\mathrm{D}}\right)^{0.85} ;
$$

Thackston and Krenkel (1969),

$$
\mathrm{K}_{2}=24.94 \frac{\left(1+(\mathrm{F})^{0.5}\right) \mathrm{u}^{*}}{\mathrm{D}},
$$

where $F$ is the Froude number (eq. 17);

$\mathrm{u}^{*}$ is the average wind shear velocity, in feet per second, defined as

$$
\mathrm{u}^{*}=(\mathrm{g} \mathrm{D} \mathrm{SL})^{0.5}
$$


Padden and Gloyna (1971),

$$
\mathrm{K}_{2}=6.87 \frac{\mathrm{V}^{0.703}}{\mathrm{D}^{1.054}}
$$

Bennett and Rathbun (1972),

$$
\mathrm{K}_{2}=106.10 \frac{\mathrm{V}^{0.413} \mathrm{SL}^{0.273}}{\mathrm{D}^{1.408}}
$$

Bennett and Rathbun (1972),

$$
\mathrm{K}_{2}=20.19 \frac{\mathrm{V}^{0.607}}{\mathrm{D}^{1.689}}
$$

Parkhurst and Pomeroy (1972),

$$
\mathrm{K}_{2}=48.39 \frac{\left(1+0.17 \mathrm{~F}^{2}\right)(\mathrm{V} \mathrm{SL})^{0.375}}{\mathrm{D}} \text {; }
$$

Bansal (1973),

$$
\mathrm{K}_{2}=4.67 \frac{\mathrm{V}^{0.6}}{\mathrm{D}^{1.4}}
$$

Tsivoglou and Neal (1976),

$$
\mathrm{K}_{2}=1.296 \frac{\mathrm{dh}}{\mathrm{dT}},
$$

where $\mathrm{dh}$ is the change in water-surface elevation between the beginning and ending points of the reach, in feet; and

$\mathrm{dT}$ is the change in centroid traveltime between the beginning and ending points of the reach, in hours;

and Smoot (1987),

$$
\mathrm{K}_{2}=683.8 \frac{\mathrm{V}^{0.5325} \mathrm{SL}^{0.6236}}{\mathrm{D}^{0.7258}} ;
$$

The 19 equations were converted to inch-pound units and the estimated reaeration coefficients are expressed in $\mathrm{d}^{-1}$ (base e units per day) corrected to $20^{\circ} \mathrm{C}$.

An error analysis comparing measured and estimated reaeration coefficients in percent can indicate the degree of uncertainty that is inherent in an individual estimating equation and define its application limits. Because scveral measured reaeration coefficients are small magnitude numbers, an equation can give consistently close estimates yet yield a high absolute crror. This could bias evaluation of the accuracy of the cquation. Additional error analysis of the standard deviation yielded a measure of the spread of residual error for each of the predicted and measured reacration coefficients of an equation. Ideally, an equation will have both a low absolute error and a small standard deviation of residuals. The error analyses of the 19 commonly used reaeration-coefficient estimating equations were statistically summarized (table 6) for three groups of stream-tracer studies based on slope of water-surface and the presence of an impoundment within the study reach. The 3 groups consisted of the 29 low-slope stream-tracer studies, the 8 low-slope stream-tracer studies on streams with a single impoundment, and 5 high-slope stream-tracer studies.

The most reliable predictions of reaeration cocfficients are obtained from equations consistently in the top rankings for lowest standard deviation of residuals and lowest mean absolute error. The unweighted error analyses of the 19 commonly used reaeration-coefficient estimating equations indicated that equation 27 (Parkhurst and Pomeroy, 1972) and equation 30 (Smoot, 1987) gave the more consistent estimate of the gas-transfer rate in all but the high-slope streams. Equation 27 was ranked first both for lowest average absolute error and standard deviation of residuals for the group of 29 low-slope stream-tracer studies with a single impoundment. Equation 30 was ranked first for the 8 single-impoundment stream-tracer studies (both average absolute error and standard deviation of residuals), and tied for first place for average absolute error in the 29 low-slope stream-tracer studies. No single equation ranked high for both average absolute error and standard deviation of residuals for the five highslope stream-tracer studies. The top three ranking equations for each of the statistical groupings are marked in table 6 with superscripts. The reader should be aware that statistical analyses on the 2 groups of less than 10 stream-tracer studies are not conclusive but may be used to identify trends.

The individual study residuals and predictive errors for the 19 commonly used equations are given in Appendix 3 at the end of this report. The ranges for all the reach characteristics for each of the groups of stream-tracer studies are in tables 3,4 , and 5 .

\section{EMPIRICAL EQUATION FOR ESTIMATING REAERATION COEFFICIENTS}

A multiple, stepwise-regression technique (P-STAT, Inc. 1989 , p. 42.13-42.14) was used to describe the 


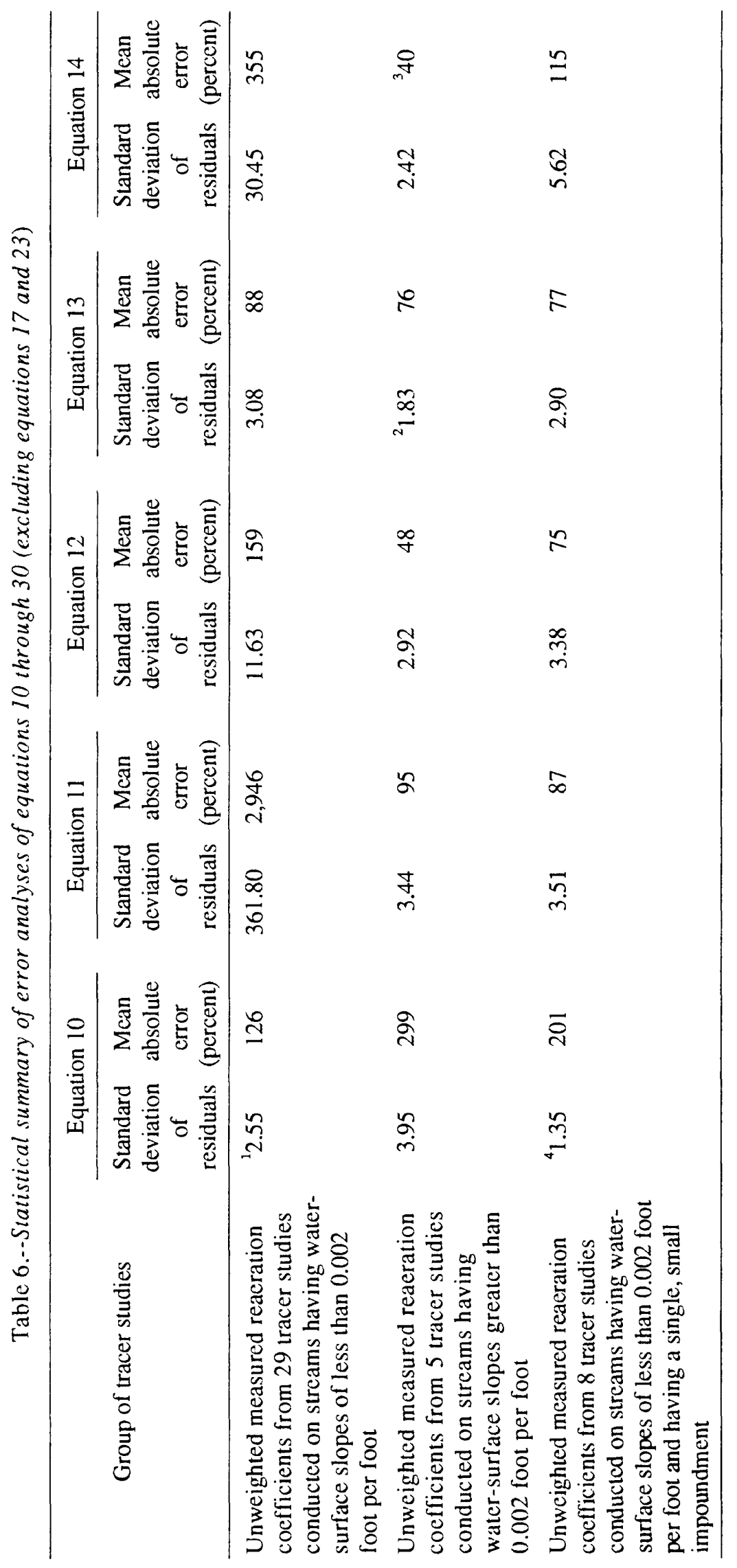




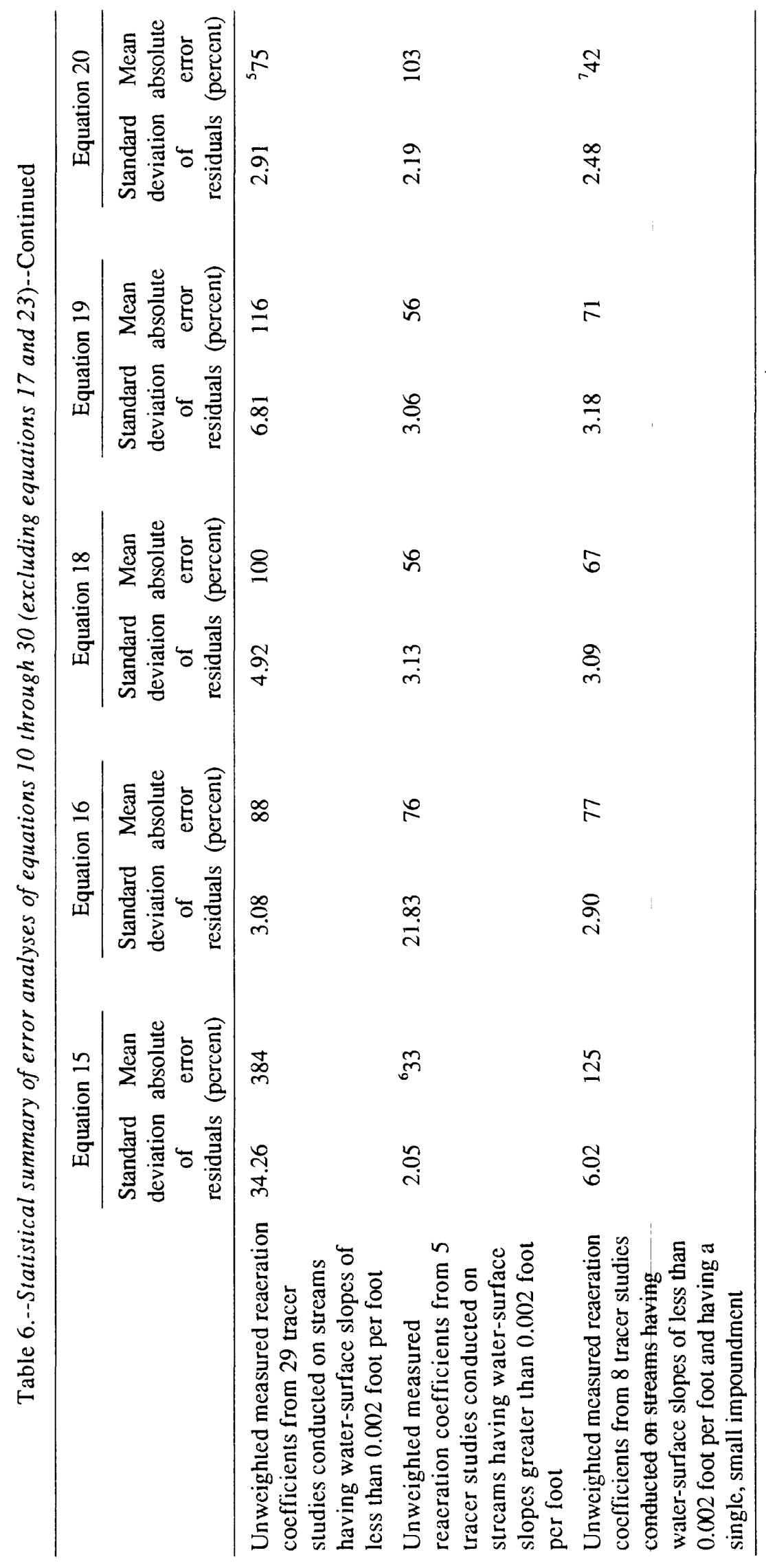




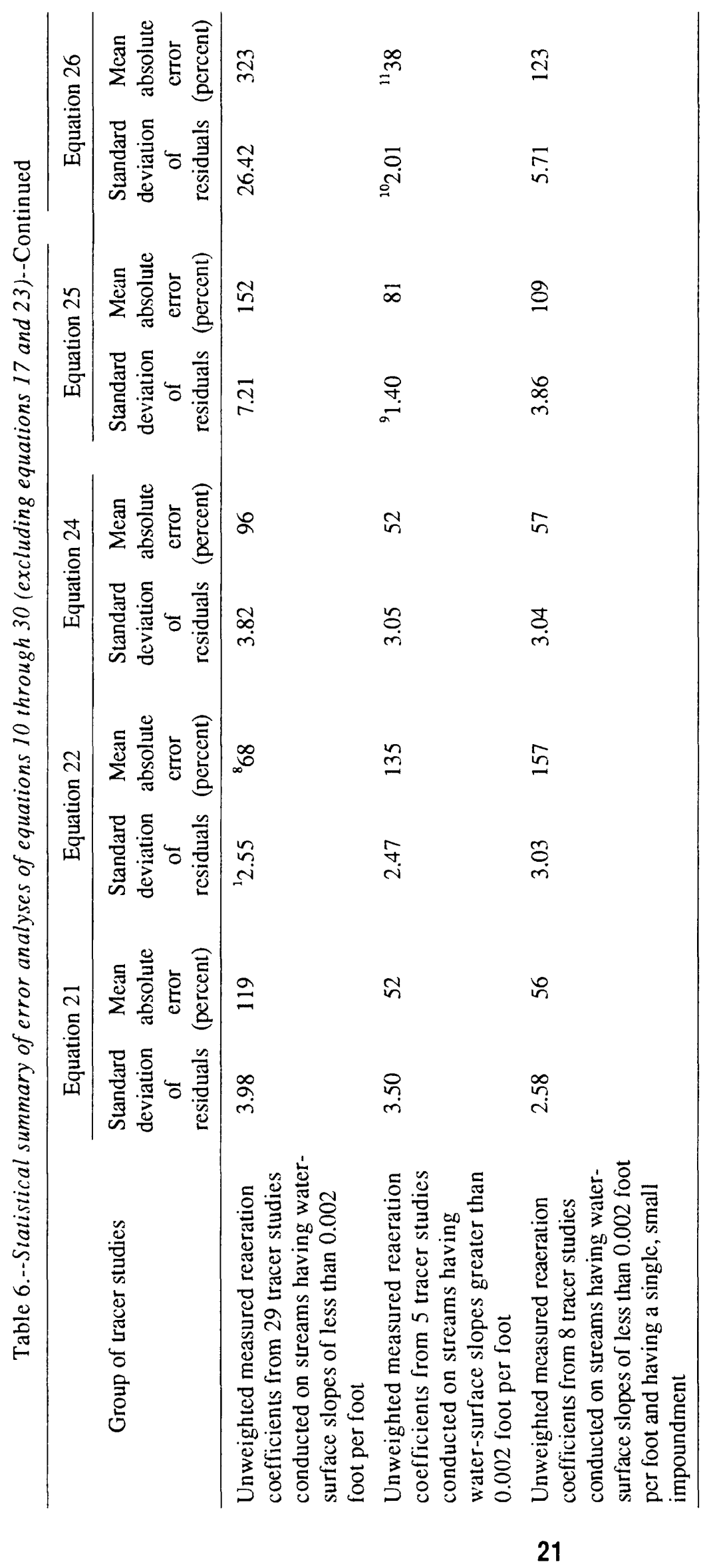




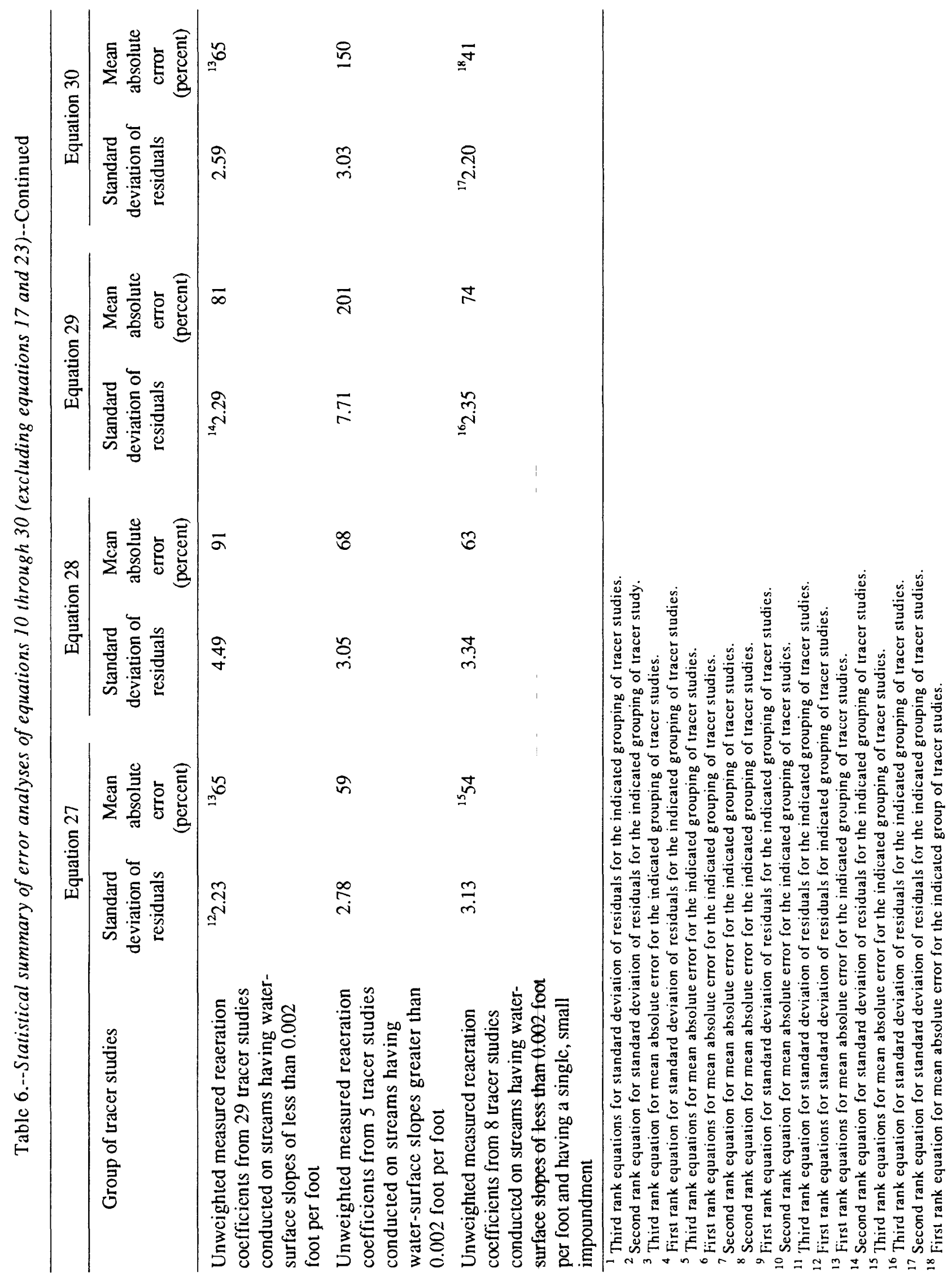


relation between dependent variables (measured reacration coefficients for 29 low-slope stream-tracer studies) and independent variables (14 reach characteristics determined for each of the tracer studies). At each step in this technique, an equation was derived by adding an independent variable with the highest absolute correlation to the dependent variable. After the variable was entered, its contribution to the equation was compared with those independent variables already in the equation. If the contribution of any independent variables weakened its correlation with the dependent variable below the confidence threshold (95 percentile), the independent variable was deleted. The potential contribution of variables that were not entered into the equation was recomputed; the independent variable with the next highest partial correlation that exceeded the confidence threshold was entered into the equation. The process continued until all variables that could meet the threshold requirements were compared.

The general form of a linear-relation equation involving dependent and independent variables is:

$\log \mathrm{Y}=\log \mathrm{h}+\mathrm{i} \log (\mathrm{H})+\mathrm{j} \log (\mathrm{I})+\mathrm{k} \log (\mathrm{J})+\ldots$

where $Y$ is the dependent variable;

$h$ is a regression constant;

$\mathrm{i}, \mathrm{j}$, and $\mathrm{k}$ are regression coefficients; and

$\mathrm{H}, \mathrm{I}$, and $\mathrm{J}$ are independent variables.

When not transformed, the linear-relation equation is:

$$
Y=h H^{i} I^{j} J^{k} \ldots
$$

Measured reaeration coefficients from each of the 29 stream-tracer studies conducted on low-slope streams were used as the dependent variables in the regression analyses. Each measured reacration coefficient used as a dependent variable was weighted with the following equation:

$$
\text { weight }=29 \frac{\left(\mathrm{L}_{m e}^{2}+\mathrm{L}_{\mathrm{e}}^{2}\right)^{-1}}{\sum\left(\mathrm{L}_{\mathrm{me}}^{2}+\mathrm{L}_{\mathrm{e}}^{2}\right)^{-1}},
$$

where 29 is the number of stream-tracer studies conducted on naturally-flowing, lowslope streams;

$$
\begin{aligned}
& \mathrm{L}_{m e} \text { is the log model error for the resulting } \\
& \text { regression equation; and } \\
& \mathrm{L}_{\mathrm{e}} \text { is the log measurement error of each } \\
& \text { tracer study. }
\end{aligned}
$$

The model error in equation 32 was estimated as 34 percent with a convergence technique for the depthaveraged reaeration-coefficient analysis.

The correlation matrix of independent variables indicated potential colinearity between color and TOC concentration (table 7). The correlation matrix also indicated potential colinearity between the resultant wind velocity parallel to the channel azimuth and corrected for mean sheltering angle and average windspeed, channel azimuth, and mean sheltering angle. Many step-regression analyses were conducted on groups of reach characteristics to account for the potential correlated variables.

The depth-averaged reaeration coefficient may be estimated by the new empirical equation:

$$
\mathrm{K}_{2}=3.83 \frac{\mathrm{SL}^{0.20}}{\mathrm{MBAS}^{0.41} \mathrm{D}^{0.76}},
$$

where SL is the water-surface slope, in foot per foot; and MBAS is the methylene-blue-active substances concentration, in milligrams per liter.

The empirical equation has an adjusted $r^{2}$ (coefficient of determination) value of 0.66 and a standard error of estimate of 71 percent. A plot relating measured and estimated reacration coefficients is shown in figure 2 .

Although many regression analyses were conducted on variations and groups of independent variables, none of the variations or groups improved the results of the regression analyses. Average windspeed, channel azimuth, mean sheltering angle, color, and suspendedsolids concentration were not included in the final analyses because the sign of their regression coefficients did not make physical or hydrological sense. Resultant wind velocity parallel to the channel azimuth and corrected for mean sheltering angle had an insufficient degree of freedom to be included in the empirical equation at the 95 -percent confidence level. Because mean stream velocity, mean width, channel elevation, TOC concentration, and specific conductance were very sensitive to sample size and model error, they were climinated in the final analysis. 


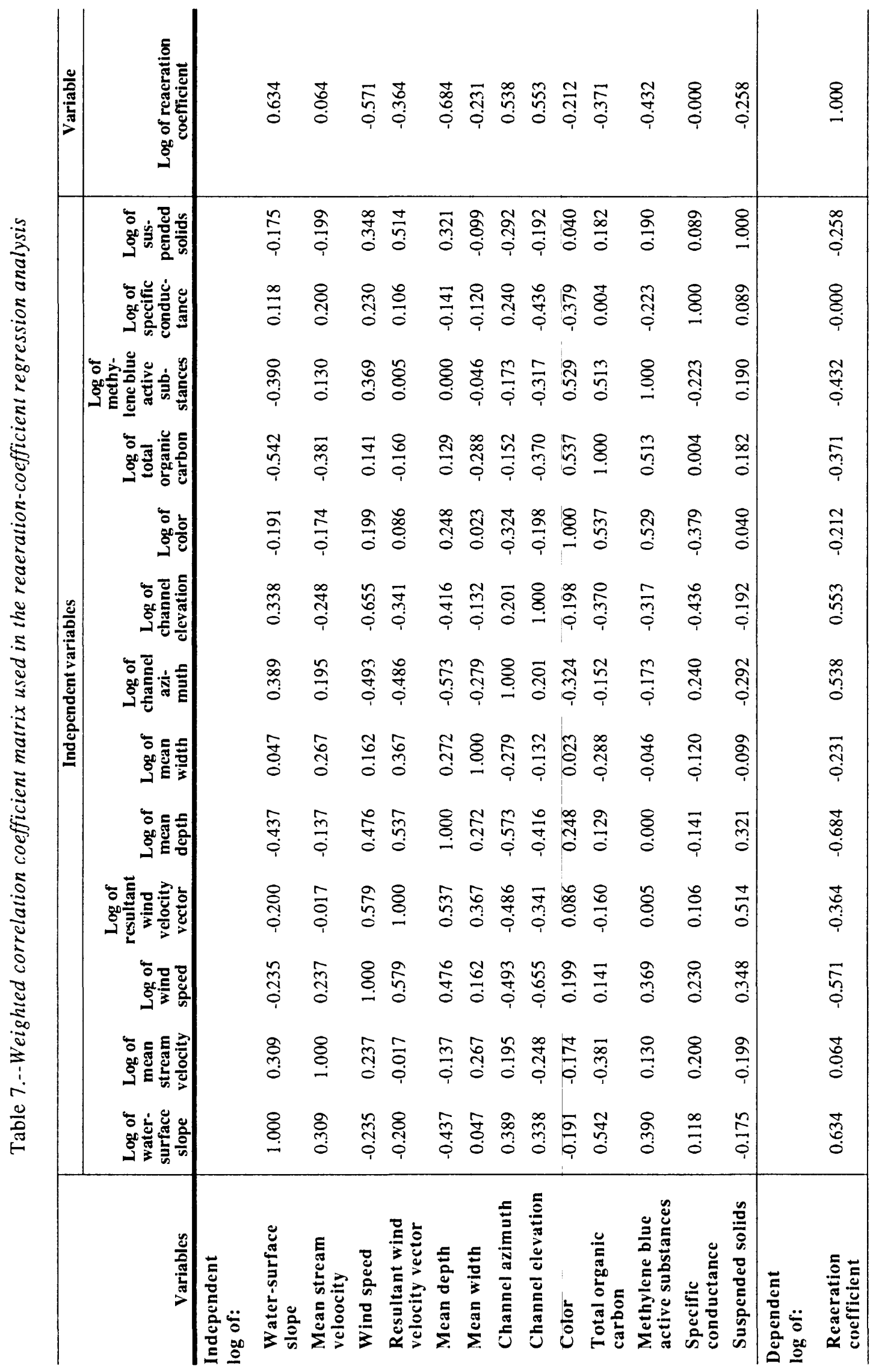




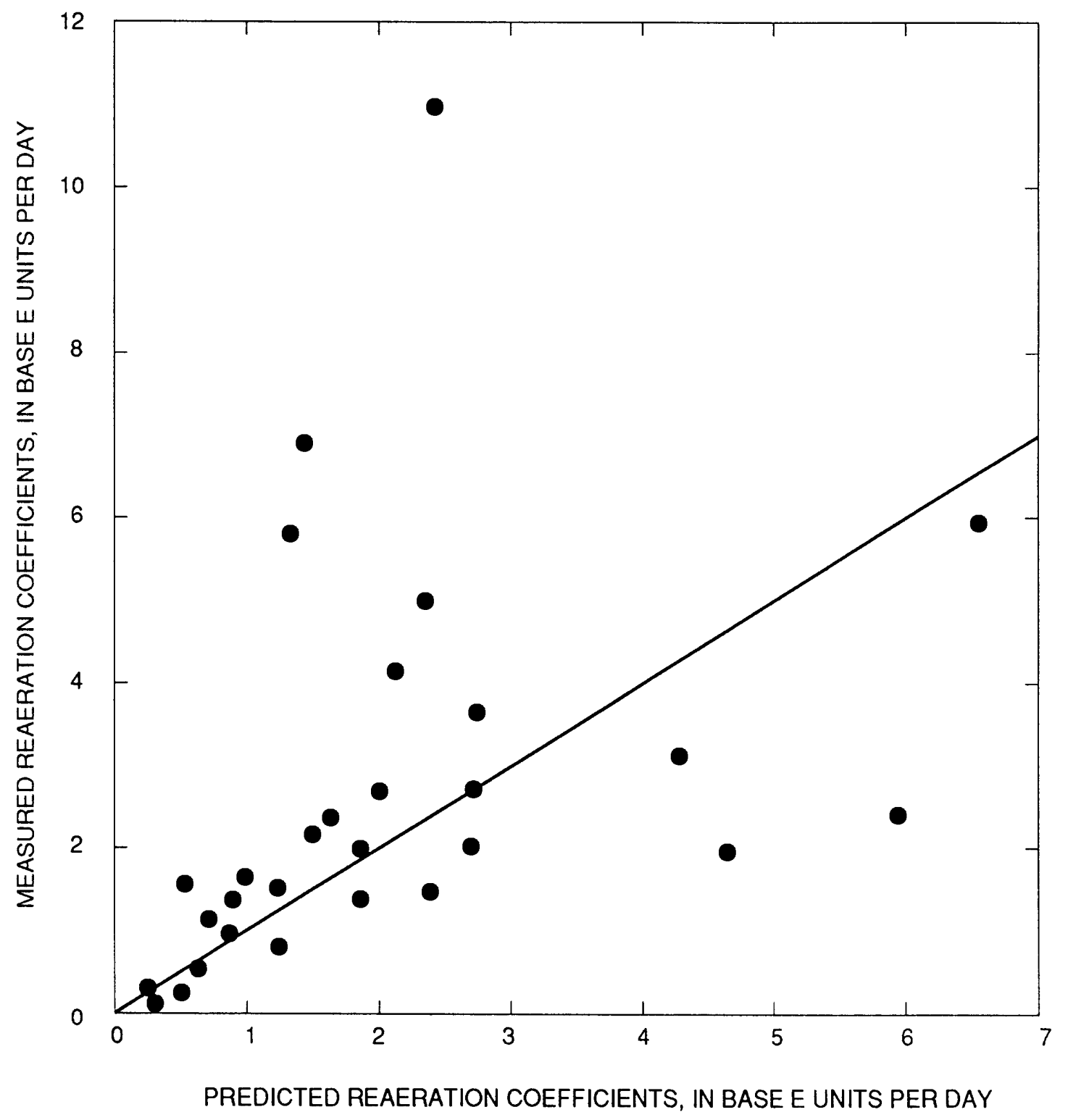

Figure 2.--Relation of measured and estimated reaeration coefficients from 29 tracer studies conducted on low-slope streams in Massachusetts and New York, 1985-88. 
MBAS concentration and mean depth were not sensitive in any of the regression analyses. The negative coefficients for these two reach characteristics (ecl. 34) are to be expected if a surfactant, as indicated by MBAS concentration, decreases surface tension and if increased depth in a stream channel reduces dynamic in-channel mixing forces caused by flow, bottom roughness, and gradual bends. The positive coefficient for the water-surface slope (eq. 34) would be expected because water-surface slope is an indication of the energy being released along a reach. The positive coefficient (eq. 34) indicates that water-surface slope is still important in understanding the gas-transfer process, even when the process is restricted to low-slope stream environments.

Two reach characteristics, water-surface slope and mean depth, are common to both equation 34 and equation 1 reported by Parker and Gay (1987) for highslope streams. The 0.20 regression coefficient for water-surface slope in equation 34 is less than half the 0.438 regression coefficient reported for the Parker and Gay (1987) equation (eq. 1). This is because mean depth and MBAS concentration are accountable for more of the variability in the dependent variable for the data base of low-slope stream-tracer studies. The results support the Parker and Gay (1987) hypothesis that additional nonencrgy reach characteristics, such as MBAS concentration, significantly affect the gastransfer process at the water-air interface in low-slope stream environments.

\section{Limitations of New Empirical Equation}

Equation 34 may be used to estimate reaeration coefficients for streams in Massachusetts and New York where reach characteristics fall within the range of minimum and maximum values given in table 3 for the 29 tracer

studies conducted on naturally-flowing low-slope streams. Particular attention should be given to the reach characteristics that are included in equation 34 --water-surface slope, mean depth, and MBAS concentration. Reacration coefficients estimated using equation 34 are for streams during steady-flow conditions.

\section{Error Analysis of New Empirical Equation}

Results from an error analysis of equation 34 are given in Appendix 4 at the end of this report. The individual study residuals and predictive errors are summarized in table 8 in two groups of stream-tracer studics. The two groups consisted of 29 tracer studies of low-slope streams and eight tracer studies on low-slope streams with a single impoundment. With a standard deviation of 2.55 and a mean absolute error of 56 percent, equation 34 is a significantly better predictor of reaeration rates for the subgroup of 29 low-slope stream studies than the eight tracer studies for low-slope streams with single impoundments. The standard deviation and mean absolute error of equation 34 for this second group was 3.73 and 152 percent, respectively. This difference in error indicates that while the single impoundment reaches are within the range of low-slope stream reach characteristics (see tables 4 and 8), the relation defined by equation 34 does not adequately reflect the gas transfer process in an impounded system.

\section{APPLICATION OF EMPIRICAL EQUATION TO A REACH}

The following example describes the application of the new empirical reacration-coefficient equation to an unstudied reach in the study area to estimate a volatileorganic-compound transfer coefficient. For the purposes of this study, the reach is considered to be unstudied.

The following steps were used to estimate reaeration coefficients and show their application for estimating final concentration from a hypothetical toluene spill on Normans Kill near Westmerc, New York (fig. 3):

1. From the Voorheesville, New York topographic map (U.S. Geological Survey, 1954; photorevised 1980), a reach was chosen from which estimations would be made. For convenient field identification, Normans Kill between the bridge on State Farm Road and the bridge on Krumkill Road was selected.

2. From the topographic map, the length of the reach was determined. The reach selected in the study was 2.4 miles or $12,700 \mathrm{ft}$.

3. Site visits to the stream reach were made to measure the reach characteristics used in solving the estimating equation. Discharge 
Table 8.--Statistical summary of error analysis for new empirical equation

[d, day]

Group of tracer studies

Standard deviation Mean absolute error

of residuals (percent)

(base e unit/d)

Unweighted measured reacration coefficients from 29 tracer studies

2.55

56

conducted on streams having water-surface slopes of less than

0.002 foot per foot

Unweighted measured reaeration coefficients from 8 tracer studies conducted on streams having water-surface slopes of less than 0.002 foot per foot and having a single, small impoundment

was measured at each end of the study reach and the width of the channel was measured in at least 20 places at evenly spaced intervals along the length of the reach. Change in water surface elevation was measured between the extremes of the study reach by differential leveling although this can most easily be completed using a total-stationlaser theodolite. Water samples were collected at both ends of the study reach to determine its MBAS concentration. For the purpose of this example, assume the discharge measured at the State Farm Road bridge is $15.4 \mathrm{ft}^{3} / \mathrm{s}$ and at the Krumkill Road bridge is $16.5 \mathrm{ft}^{2} / \mathrm{s}$ for an average discharge of $16 \mathrm{ft}^{3} / \mathrm{s}$. Assume the average channel width is 50 feet and the change in water-surface elevation is $15 \mathrm{ft}$. Assume the average MBAS concentration is $0.02 \mathrm{mg} / \mathrm{L}$ and the water temperature is $20^{\circ} \mathrm{C}$.

4. For greatest accuracy, two methods were available for determining the mean velocity for the study reach. The easiest method would be to use the results of a previously completed time-of-travel study. This information may be available from local, State, or Federal agencies. If this historic information were available, a dye-tracer time-oftravel study could be conducted to determine mean velocity. In this study, assume historic time-of-travel data indicated centroid time of travel was 9.4 hours and that mean velocity was $0.38 \mathrm{ft} / \mathrm{s}$ for the flow duration of interest.

5. Equation 4 was used to calculate a reach mean depth, D:

$$
D=\frac{16}{(0.38)(50)}=0.84 \text { feet }
$$

6. Channel slope was calculated by dividing the change in water-surface clevation at the extremes of the reach by the reach length. The calculated channel slope is $0.0012 \mathrm{ft} / \mathrm{ft}$.

7. Equation 34 was used to estimate the reaeration coefficient:

$$
\begin{aligned}
K_{2} & =3.83 \frac{(0.0012)^{0.20}}{(0.02)^{0.41}(0.84)^{0.76}} \\
& =5.7 \text { per day } .
\end{aligned}
$$




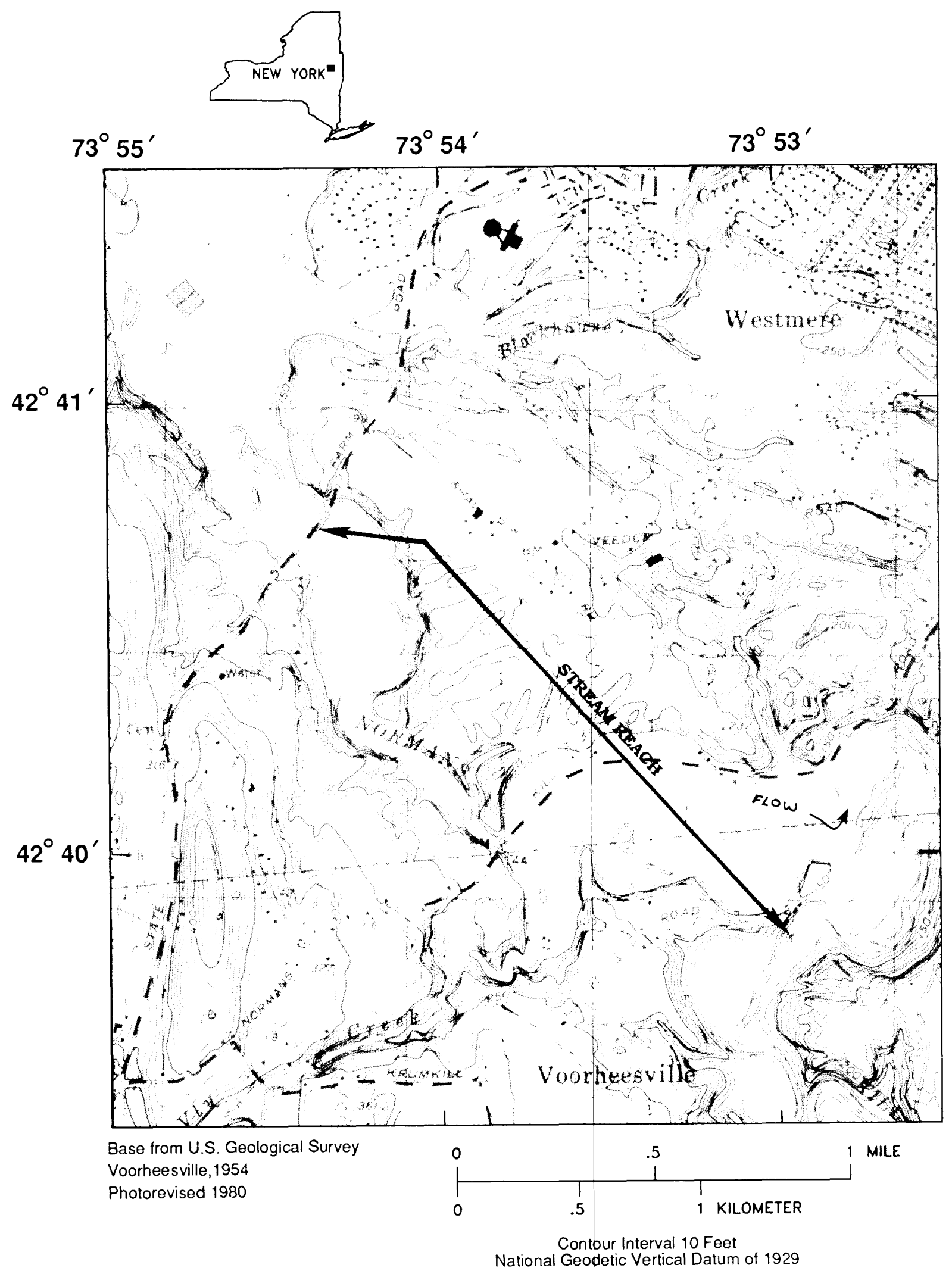

Figure 3.--Location of stream reach on Normans Kill near Westmere, New York. 
Because the ambient water temperature is already at the base temperature of $20^{\circ} \mathrm{C}$, no temperature correction needs to be made.

8. Toluene is a volatile-organic compound on the USEPA list of priority pollutants (Keith and Telliard, 1979). Rathbun and Tai (1981) reported that the volatilization coefficient for toluene can be estimated with the following relation:

$$
\mathrm{K}_{\text {toluene }}=0.655 \mathrm{~K}_{2}
$$

Rathbun and Tai (1981) limited the application of this estimating technique to toluene, benzene, chloroform, and methylene chloride because all have Henry's law constants larger than $10^{-3} \mathrm{~atm}-\mathrm{m}^{3} \mathrm{~mol} / \mathrm{g}$ (atmospherescubic meters-moles per gram) and therefore, are in the range of conditions where the liquid film is the controlling resistance to the mass-transfer process. The toluene concentration $\left(\mathrm{C}_{\text {toluene }}\right)$ at the downstream end of the example reach, assuming a toluene concentration $\left(\mathrm{C}_{\mathrm{o}, \text { toluene }}\right)$ of $100 \mathrm{mg} / \mathrm{L}$ at the upstream end of the reach, can be estimated with equation 1 and 35 :

$$
\begin{aligned}
\mathrm{C}_{\text {toluene }}= & (100) \exp [-(5.7)(0.655)(9.4 / 24)] \\
= & 23 \mathrm{mg} / \mathrm{L} \text { at the end of the reach or a } \\
& 78 \text { percent reduction in concentration. }
\end{aligned}
$$

\section{SUMMARY}

The steady-state propane-gas-tracer method was used to measure reaeration coefficients from 42 streamtracer studies conducted on 33 reaches of 22 streams in Massachusetts and New York. The stream-tracer studies were conducted during medium- and low-flow periods from May 1985 through October 1988. Also determined from each tracer study were 14 hydraulic, physical, and water-quality reach characteristics. The hydraulic and physical characteristics of the reaches were: water-surface slope, mean stream velocity, avcrage windspeed reported at the closest NOAA weather station, resultant wind velocity parallel to the channel azimuth (and corrected for the mean shelter- ing angle), mean depth, mean width, channel azimuth, channel elevation, and mean sheltering angle. The water-quality reach characteristics were color, concentration of total organic carbon, concentration of methylene-blue-active substances, specific conductance, and concentration of suspended-solids.

Multiple-regression techniques were applied to data from 29 stream-tracer studies conducted on naturallyflowing low-slope streams without impoundments. The regression analyses, which related dependent variables (measured reaeration coefficients) to independent variables (14 reach characteristics), yielded the following empirical equation for estimating reaeration coefficients:

$$
\mathrm{K}_{2}=3.83 \frac{\mathrm{SL}^{0.20}}{\mathrm{MBAS}^{0.41} \mathrm{D}^{0.76}}
$$

where the equation has a standard error of estimate of 71 percent. Only those variables significant at the 95-percent confidence level were retained in the final equation.

For 19 commonly used equations for estimating reaeration coefficients, the most reliable estimations of measured reaeration coefficients from the 29 lowslope stream-tracer studies were obtained from equation 27 (Parkhurst and Pomeroy, 1972):

$$
\mathrm{K}_{2}=48.39 \frac{\left(1+0.17 \mathrm{~F}^{2)}(\mathrm{V} \mathrm{SL})^{0.375}\right.}{\mathrm{D}}
$$

The Parkhurst and Pomeroy (1972) equation ranked first for both average absolute error and standard deviation of residuals for the group of 29 low-slope streamtracer studies and third for average absolute error for the eight low-slope tracer studies on streams with a single impoundment. The most reliable estimations of measured reaeration coefficients from the eight lowslope stream-tracer studies with a single impoundment were obtained by equation 30 (Smoot, 1987):

$$
\mathrm{K}_{2}=683.8 \frac{\mathrm{V}^{0.5325} \mathrm{SL}^{0.6236}}{\mathrm{D}^{0.7258}}
$$

The Smoot (1987) equation ranked first for eight tracer studies on low-slope streams with a single impoundment for both average absolute error and standard deviation of residuals, and tied for first place in rank for the average absolute error for the 29 low-slope streamtracer studies. 


\section{REFERENCES CITED}

Bansal, M.K., 1973, Atmospheric reaeration in natural streams: Water Research, v. 7, no. 5, p. 769-782.

Bennett, J.P., and Rathbun, R.E., 1972, Reaeration in open-channel flow: U.S. Geological Survey Professional Paper 737,75 p.

Buchanan, T.J., and Somes, W.P., 1969, Discharge measurements at gaging stations: U.S. Geological Survey Techniques of Water-Resources Investigations, book 3, chap. A8, 65 p.

Cadwallader, T.E., and McDonnell, A.J., 1969, A multivariate analysis of reacration data: Water Research, v. 3, p. 731-742.

Churchill, M.A., Elmore, H.L., and Buckingham, E.A., 1962, The prediction of stream reaeration rates: American Society of Civil Engineers, Journal of the Sanitary Engineering Division, v. 88, no. SA-4, p. $1-46$.

Chiou, C.T., Kohnert, R.L., Freed, V.H., and Tonkyn, R.G., 1983, Prediction of evaporative loss rates of solutes in stagnant and turbulent waters in relation to rates of reference materials: Environment International, v. 9, p. 13-17.

Delaney, D.F., and Gay, F.B., 1980, Hydrology and water resources of the coastal drainage basins of northeastern Massachusetts, from Castle Neck River, lpswich, to Mystic River, Boston: U.S. Geological Survey Hydrologic Investigations Atlas HA-589, 4 sheets.

Dobbins, W.E., 1965, Closure to BOD and oxygen relationship in streams: American Society of Civil Engineers, Journal of the Sanitary Engineering Division, v. 91, no. SA-5, p. 49-55.

Goerlitz, D.F., and Brown, Eugene, 1972, Methods for analysis of organic substances in water: U.S. Geological Survey Techniques of Water-Resources Investigations, book 5, chap. A3, 40 p.

Hubbard, E.F., Kilpatrick, F.A., Martens, L.A., and Wilson, J.R., Jr., 1982, Measurement of time of travel and dispersion in streams by dye tracing: U.S. Geological Survey Techniques of Water-Resources Investigations, book 3, chap. A9, 44 p.

Isaac, W.P., and Gaudy, A.F., 1968, Atmospheric oxygenation in a simulated stream: American Society of Civil Engineers, Journal of the Sanitary Engineering Division, v. 94, no. SA-2, p. 319-344.
Keith, L.H., and Telliard, W.A., 1979, Priority pollutants I--A perspective view: Environmental Science and Technology, v. 13, p. 416-426.

Kilpatrick, F.A., and Cobb, E.D., 1984, Measurement of discharge using tracers: U.S. Geological Survey Open-File Report 84-136, 73 p.

Kilpatrick, F.A., Rathbun, R.E., Yotsukura, Nobuhiro, Parker, G.W., and DeLong, L.L., 1987, Determination of stream reaeration coefficients by use of tracers: U.S. Geological Survey Open-File Report $87-245,84 \mathrm{p}$.

Krenkel, P.A., and Orlob, G.T., 1963, Turbulent diffusion and the reaeration coefficient: Proceedings of the American Society of Civil Engineers, v. 128, paper 3491, p. 293-334.

Langbein, W.B., and Durum, W.H., 1967, The aeration capacity of streams: U.S. Geological Survey Circular $542,6 \mathrm{p}$.

National Occanic and Atmospheric Administration, 1985, Local climatological data, Worcester, Massachusetts.

1986a, Local climatological data, Worcester, Massachusetts.

1986b, Local climatological data, Albany, New York.

1987a, Local climatological data, Albany, New York.

1987b, Local climatological data, Boston, Massachusetts.

1987c, Local climatological data, Hartford, Connecticut.

1987d, Local climatological data, Worcester, Massachusetts.

1988a, Local climatological data, Albany, New York.

1988b, Local climatological data, Boston, Massachusetts.

1988c, Local climatological data, Hartford, Connecticut.

1988d, Local climatological data, Worcester, Massachusetts.

Negulescu, M., and Rojanski, V., 1969, Recent research to determine reaeration coefficients: Water Research, v. 3, no. 3, p. 189-202. 
O'Connor, D.J., and Dobbins, W.E., 1958, Mechanics of reaeration in natural streams: Proceedings of the American Society of Civil Engineers, v. 123, p. 641-684.

Owens, M., Edwards, R.W., and Gibbs, J.W., 1964, Some reaeration studies in streams: Oxford, England, International Journal of Air and Water Pollution, v. 8, no. $8 / 9$, p. $469-486$.

Padden, T.J., and Gloyna, E.F., 1971, Simulation of stream processes in a model river: Austin, University of Texas, Report EHE-70-23, CRWR-72, 130 p.

Parker, G.W., and Gay, F.B., 1987, Equation to estimate reaeration coefficients in Massachusetts streams: U.S. Geological Survey Water-Resources Investigations Report 86-4111, 34 p.

Parker, G.W., and Hunt, G.S., 1983, Initial assessment of time of travel and mixing through Gulf Island Pond and the Lower Androscoggin River, Maine: U.S. Geological Survey Water-Resources Investigations Report 83-4020, 53 p.

Parkhurst, J.D., and Pomeroy, R.D., 1972, Oxygen absorption in streams: American Society of Civil Engineers, Journal of the Sanitary Engineering Division, v. 98, no. SA-1, p. 101-124.

Rainwater, K.A., and Holley, E.R., 1983, Laboratory studies of the hydrocarbon gas tracer technique for reacration measurement: Center of Research in Water Resources Report 189, Austin, University of Texas, $143 \mathrm{p}$.

Rathbun, R.E., Stephens, D.W., Shultz, D.J., and Tai, D.Y., 1978, Laboratory studies of gas tracers for reaeration: American Society of Civil Engincers, Journal of the Environmental Engineering Division, v. 104, no. EE2, p. 215-229.

Rathbun, R.E., and Tai, D.Y., 1981, Technique for determining the volatilization coefficients of priority pollutants in streams: Water Research, v. 15, p. 243-250.

Shultz, R.E., Pankow, J.F., Tai, D.Y., Stephens, D.W., and Rathbun, R.E., 1976, Determination, storage, and preservation of low molecular weight hydrocarbon gases in aqueous solution: Journal of Research of the U.S. Geological Survey, v. 4, no. 2, p. 247251.

Skougstad, M.W., Fishman, M.J., Friedman, L.C. Erdmann, D.E., and Duncan, S.S., 1979, Methods for determination of inorganic substances in water and fluvial sediments: U.S. Geological Survey Techniques of Water-Resources Investigations, book 5 , chap. Al, 626 p.
Smoot, J.L., 1987, Effect of streamflow conditions on gas-transfer coefficients: Proceedings of the 1987 National Conference on Hydraulic Engineering, American Society of Civil Engineers, Journal of the Hydraulics Division, p. 980-985.

Thackston, E.C., and Krenkel, P.A., 1969, Reaeration prediction in natural streams: American Society of Civil Engineers, Journal of the Sanitary Engineering Division, v. 95, no. SA-1, p. 65-94.

Tsivoglou, E.C., and Neal, L.A., 1976, Tracer measurement of reaeration, part III, Predicting the reaeration capacity of inland streams: Journal of the Water Pollution Control Federation, v. 48, no. 12, p. 2669-2689.

U.S. Geological Survey, 1954, Voorheesville, New York, quadrangle: scale 1:24,000, photorevised 1980, 1 sheet.

Yotsukura, Nobuhiro, and Kilpatrick, F.A., 1973, Tracer simulation of soluble waste concentration: American Society of Civil Engineers, Joumal of the Fnvironmental Engineering Division, v. 99, no. LE-4, p. $499-515$.

Yotsukura, Nobuhiro, Stedfast, D.A., Draper, R.E., and Brutsaert, W.H., 1983, An assessment of the steadystate gas-tracer method for reaeration coefficients-Cowaselon Creek, New York: U.S. Geological Survey Water-Resources Investigations Report 83$4183,88 \mathrm{p}$.

Yotsukura, Nobuhiro, Stedfast, D.A., and Jirka, G.H., 1984, An assessment of the steady-state propanegas tracer method for reaeration coefficients Chenango River, New York: U.S. Geological Survey Water-Resources Investigations Report 84 $4368,69 \mathrm{p}$. 


\section{GLOSSARY OF TERMS}

A, area under dye-tracer response curve, in microgram per liter hour.

coth, hyperbolic cotangent of angle, in radians.

C, dissolved-gas concentration, in micrograms per liter.

$\mathrm{C}_{\mathrm{c}, \mathrm{i}}$, dye concentration at $\mathrm{i}^{\mathrm{th}}$ hour since start of injection, in micrograms per liter.

d, subscript that designates downstream sampling site.

dh, change in water-surface elevation between beginning and ending points of reach, in feet.

dT, change in centroid traveltime between beginning and ending points of reach, in hours.

D, mean depth, feet.

E, measurement error.

$\mathbf{E}_{\mathrm{r}}$, relative crror of gas-concentration measurements and discharge measurements.

F, Froude number.

g, acceleration caused by gravity, in feet per second squared.

h, regression constant.

$\mathbf{H}$, independent variable.

i, regression coefficient.

I, independent variable.

j, regression coefficient.

$\mathbf{J}$, independent variable.

$\mathbf{k}$, regression coefficient.

$\mathbf{K}$, absorption or desorption coefficient, in units per time.

$\mathbf{K}_{\mathbf{2}}$, depth-averaged reaeration coefficient at standard temperature of 20 degrees Celsius, in base e units per day.

KL, water-surface-film transfer coefficient.

Kp, actual propane-gas depth-averaged desorption coefficient, in base e units per hour.

$\mathbf{K} \mathbf{p}^{\prime}$, initial estimate of propane-gas depth-averaged desorption coefficient, in base e units per hour.

$\mathbf{L}$, reach length, in feet.

$\mathbf{L}_{\mathfrak{e}}, \log$ measurement error of each tracer study.

$\mathbf{L}_{\mathbf{m e}}$, log model error for resulting regression equation.

MBAS, methylene-blue active-substances concentration, in milligrams per liter.

Q, discharge determined by averaging measured discharge at each sampling site, in cubic feet per second.

$\mathbf{r}^{2}$, cocfficient of determination.

ROE, total dissolved-solids concentration, in milligrams per liter.

SC, specific conductance, microsiemens per centimeter at 25 degrees Celsius.

SL, water-surface slope, in foot per foot. 
SS, suspended-solids concentration, in milligrams per liter.

$\mathbf{t}$, ambient water temperature, in degrees Celsius.

T, time.

$\overline{\mathbf{T}}$, centroid traveltime of a slug-injected dye-tracer response curve measured at a sampling site.

$\mathbf{T}_{\mathbf{i}}, \mathrm{i}^{\text {th }}$ hour since start of injection.

u, subscript that designates upstream sampling site.

$\mathbf{u}^{*}$, average wind shear velocity, in feet per second.

$\mathbf{V}$, mean streamflow velocity, in feet per second.

$\mathbf{W}$, mean width, in feet.

Y, dependent variable.

$\mathbf{2 4}$, constant to convert hours to days.

29, number of tracer studies conducted on naturally-flowing low-sloped streams used in error analysis. 


\section{APPENDIXES}




\begin{tabular}{|c|c|c|c|}
\hline Stream name & Sampling site & Location and description & Study date \\
\hline \multirow{9}{*}{$\begin{array}{l}\text { Beaver Brook near } \\
\text { Littleton, Mass. }\end{array}$} & Site 1 near & Lat. $42^{\circ} 31^{\prime} 00^{\prime \prime}$ N., long. $71^{\circ} 31^{\prime} 24^{\prime \prime}$ E., Middlesex & $6-17-86$ \\
\hline & Littleton & County, 0.7 miles upstream of State Highway 2 & \\
\hline & & bridge, 1.6 miles southwest of Littleton, Mass. & \\
\hline & Site 2 near & Lat. $42^{\circ} 31^{\prime} 32^{\prime \prime}$ N., long. $71^{\circ} 31^{\prime} 08^{\prime \prime}$ E., Middlesex & $6-17-86$ \\
\hline & Littleton & County, upstream of State Highway 2 bridge, & \\
\hline & & 1.0 miles southwest of Littleton, Mass. & \\
\hline & & Reach: A - Site 1 to site 2 & \\
\hline & & Reach length: 0.7 mile & \\
\hline & & $\begin{array}{l}\text { Wetland vegetation: Forested, scrub/shrub, and } \\
\text { emergent }\end{array}$ & \\
\hline \multirow{16}{*}{$\begin{array}{l}\text { Assabet River } \\
\text { near Westborough, } \\
\text { Mass. }\end{array}$} & Site 1 near & Lat. $42^{\circ} 16^{\prime} 46^{\prime \prime}$ N., long. $71^{\circ} 38^{\prime} 19^{\prime \prime}$ E., Worcester & $5-13-86$ \\
\hline & Westborough & County, 1,400 feet upstream of State Highway 9 & $8-05-86$ \\
\hline & & bridge, 1.5 miles northwest of Westborough, & $10-28-86$ \\
\hline & & Mass. & \\
\hline & Site 2 near & Lat. $42^{\circ} 17^{\prime} 16^{\prime \prime}$ N., long. $71^{\circ} 38^{\prime} 35^{\prime \prime}$ E., Worcester & $5-13-86$ \\
\hline & Westborough & County, at town line, 2,000 feet downstream & $8-05-86$ \\
\hline & & from State Highway 9 bridge, 2.0 miles & $10-28-86$ \\
\hline & & northwest of Westborough, Mass. & \\
\hline & Site 3 near & Lat. $42^{\circ} 10^{\prime} 16^{\prime \prime}$ N., long. $71^{\circ} 37^{\prime} 44^{\prime \prime}$ E., Worcester & $8-05-86$ \\
\hline & Northborough & County, upstream side School Street Bridge, & \\
\hline & & 1.3 miles southeast of Northborough, Mass. & \\
\hline & & Reach: A - Site 1 to site 2 & \\
\hline & & Reach length: 0.7 mile & \\
\hline & & Reach: B - Site 2 to site 3 & \\
\hline & & Reach length: 1.8 miles & \\
\hline & & Welland vegetation: Forested and scrub/shrub & \\
\hline
\end{tabular}


Appendix 1.--Study-reach location and descriptions--Continued

\begin{tabular}{|c|c|c|c|}
\hline Stream name & Sampling site & Location and description & Study date \\
\hline \multirow{9}{*}{$\begin{array}{l}\text { Sudbury River } \\
\text { near Wayland, } \\
\text { Mass. }\end{array}$} & Site 1 near & Lat. $42^{\circ} 22^{\prime} 27^{\prime \prime}$ N., long. $71^{\circ} 22^{\prime} 56^{\prime \prime}$ E., Middlesex & $11-16-87$ \\
\hline & Wayland & County, upstream side State Highway 27 & \\
\hline & & bridge, 1.3 miles northwest of Wayland, Mass. & \\
\hline & Site 2 near & Lat. $42^{\circ} 23^{\prime} 41^{\prime \prime}$ N., long. $71^{\circ} 21^{\prime} 55^{\prime \prime}$ E., Middlesex & $11-16-87$ \\
\hline & Wayland & County, upstream side Sherman Bridge, & \\
\hline & & 2.3 miles north of Wayland, Mass. & \\
\hline & & Reach: A - Site 1 to site 2 & \\
\hline & & Reach length: 2.8 miles & \\
\hline & & Wetland vegetation: Scrub/shrub and emergent & \\
\hline \multirow{16}{*}{$\begin{array}{l}\text { Ipswich River } \\
\text { near Topsfield, } \\
\text { Mass. }\end{array}$} & Site 1 near & Lat. $42^{\circ} 37^{\prime} 41^{\prime \prime}$ N., long. $70^{\circ} 55^{\prime} 02^{\prime \prime}$ E., Essex & $6-23-87$ \\
\hline & Topsfield & County, at Bunker Meadows, 1.7 miles & \\
\hline & & downstream from mouth of Salem-Beverly & \\
\hline & & Waterway Canal, 1.9 miles west of & \\
\hline & & Topsfield, Mass. & \\
\hline & Site 2 near & Lat. $42^{\circ} 39^{\prime} 13^{\prime \prime}$ N., long. $70^{\circ} 54^{\prime} 44^{\prime \prime}$ E., Essex & $6-23-87$ \\
\hline & Topsfield & County, at Hamilton Road Bridge, 2.3 miles & \\
\hline & & northwest of Topsfield, Mass. & \\
\hline & Site 3 near & Lat. $42^{\circ} 39^{\prime} 34^{\prime \prime}$ N., long. $70^{\circ} 53^{\prime} 41^{\prime \prime}$ E., Essex & $6-23-87$ \\
\hline & Ipswich & County, at Willowdale Dam, 2.9 miles & \\
\hline & & northwest of Topsfield, Mass. & \\
\hline & & Reach: A - Site 1 to site 2 & \\
\hline & & Reach length: 4.1 miles & \\
\hline & & Reach: B - Site 2 to site 3 & \\
\hline & & Reach length: 1.4 miles & \\
\hline & & Wetland vegetation: Scrub/shrub and emergent & \\
\hline
\end{tabular}


Appendix 1.--Study-reach location and descriptions--Continued

\begin{tabular}{|c|c|c|c|}
\hline Stream name & Sampling site & Location and description & Study date \\
\hline \multirow{9}{*}{$\begin{array}{l}\text { Taunton River } \\
\text { near Bridgewater, } \\
\text { Mass. }\end{array}$} & Site 1 near & Lat. $41^{\circ} 57^{\prime} 47^{\prime \prime}$ N., long. $70^{\circ} 54^{\prime} 46^{\prime \prime}$ E., Plymouth & $5-03-88$ \\
\hline & Bridgewater & County, at bridge on Auburn Street, 3.7 miles & $8-23-88$ \\
\hline & & southeast of Bridgewater, Mass. & \\
\hline & Site 2 at & Lat. $41^{\circ} 57^{\prime} 47^{\prime \prime}$ N., long. $70^{\circ} 54^{\prime} 46^{\prime \prime}$ E., Plymouth & $5-03-88$ \\
\hline & South & County, at Woodward Bridge on Summer Street, & $8-23-88$ \\
\hline & Bridgewater & 0.7 miles east of South Bridgewater, Mass. & \\
\hline & & Reach: A - Site 1 to site 2 & \\
\hline & & Reach length: 2.4 miles & \\
\hline & & Wetland vegetation: Forested & \\
\hline \multirow{13}{*}{$\begin{array}{l}\text { French River } \\
\text { near Oxford, } \\
\text { Mass. }\end{array}$} & Site 1 near & Lat. $42^{\circ} 08^{\prime} 48^{\prime \prime}$ N., long. $71^{\circ} 52^{\prime} 31^{\prime \prime}$ E., Worcester & $10-21-87$ \\
\hline & Oxford & County, 0.3 miles upstream of Wellington & $6-21-88$ \\
\hline & & Brook, 2.1 miles northwest of Oxford, Mass. & $9-23-88$ \\
\hline & Site 2 near & Lat. $42^{\circ} 08^{\prime} 14^{\prime \prime}$ N., long. $71^{\circ} 53^{\prime} 03^{\prime \prime}$ E., Worcester & $10-21-87$ \\
\hline & Oxford & County, at end of Charlton Road, 1.8 miles & $6-21-88$ \\
\hline & & northwest of Oxford, Mass. & $9-23-88$ \\
\hline & Site 3 at & Lat. $42^{\circ} 07^{\prime} 52^{\prime \prime}$ N., long. $71^{\circ} 52^{\prime} 50^{\prime \prime}$ E., Worcester & $9-23-88$ \\
\hline & Oxford & County, at pipeline crossing, 0.8 miles west & \\
\hline & & of Oxford, Mass. & \\
\hline & Site 4 at & Lat. $42^{\circ} 07^{\prime} 06^{\prime \prime}$ N., long. $71^{\circ} 52^{\prime} 54^{\prime \prime}$ E., Worcester & $10-21-87$ \\
\hline & Oxford & County, on right bank at Hodges Village, & $6-21-88$ \\
\hline & & 240 feet downstream from Hodges Village Dam, & \\
\hline & & 0.8 miles west of Oxford, Mass. & \\
\hline
\end{tabular}


Appendix 1.--Study-reach location and descriptions--Continued

\begin{tabular}{|c|c|c|c|}
\hline Stream name & Sampling site & Location and description & Study date \\
\hline French River near & & Reach: A - Site 1 to site 2 & \\
\hline Oxford, Mass.-- & & Reach length: 1.0 miles & \\
\hline \multirow[t]{7}{*}{ Continued } & & Wetland vegetation: Forested & \\
\hline & & Reach: B - Site 2 to site 3 & \\
\hline & & Reach length: 0.7 mile & \\
\hline & & Wetland vegetation: Forested and scrub/shrub & \\
\hline & & Reach: C - Site 2 to site 4 & \\
\hline & & Reach length: 1.8 miles & \\
\hline & & $\begin{array}{l}\text { Wetland vegetation: Forested, scrub/shrub, and } \\
\text { emergent }\end{array}$ & \\
\hline \multirow{10}{*}{$\begin{array}{l}\text { Otter River } \\
\text { near Gardner, } \\
\text { Mass. }\end{array}$} & Site 1 near & Lat. $42^{\circ} 34^{\prime} 29^{\prime \prime}$ N., long. $72^{\circ} 01^{\prime} 22^{\prime \prime}$ E., Worcester & $5-19-87$ \\
\hline & Gardner & County, at bridge on town road, 3,900 feet & \\
\hline & & downstrcam from Gardner sewage treatment & \\
\hline & & plant, 1.2 miles west of Gardner, Mass. & \\
\hline & Site 2 near & Lat. $42^{\circ} 35^{\prime} 02^{\prime \prime}$ N., long. $72^{\circ} 02^{\prime} 33^{\prime \prime}$ E., Worcester & $5-19-87$ \\
\hline & Gardner & County, at Boston and Maine Railroad bridge, & \\
\hline & & 2.4 miles west of Gardner, Mass. & \\
\hline & & Reach: A - Site 1 to site 2 & \\
\hline & & Reach length: 2.0 miles & \\
\hline & & $\begin{array}{l}\text { Wetland vegetation: Forested, scrub/shrub, and } \\
\text { emergent }\end{array}$ & \\
\hline \multirow{7}{*}{$\begin{array}{l}\text { Mill River } \\
\text { near Amherst, } \\
\text { Mass. }\end{array}$} & Site 1 near & Lat. $42^{\circ} 23^{\prime} 18^{\prime \prime}$ N., long. $72^{\circ} 32^{\prime} 24^{\prime \prime}$ E., Hampshire & $8-03-87$ \\
\hline & Amherst & County, 500 feet upstream from bridge on & \\
\hline & & State Highway $116,1.5$ miles northwest of & \\
\hline & & Amherst, Mass. & \\
\hline & Site 2 near & Lat. $42^{\circ} 23^{\prime} 10^{\prime \prime}$ N., long. $72^{\circ} 33^{\prime} 03^{\prime \prime}$ E., Hampshire & $8-03-87$ \\
\hline & Amherst & County, at bridge on Maple Street, & \\
\hline & & 1.6 miles east of North Hadley, Mass. & \\
\hline
\end{tabular}


Appendix 1.--Study-reach location and descriptions--Continued

\begin{tabular}{|c|c|c|c|}
\hline Stream name & Sampling site & Location and description & Study date \\
\hline $\begin{array}{l}\text { Mill River } \\
\text { near Amherst, } \\
\text { Mass.--Continued }\end{array}$ & $\begin{array}{l}\text { Site } 3 \text { at } \\
\text { North Hadley }\end{array}$ & $\begin{array}{l}\text { Lat. } 42^{\circ} 23^{\prime} 27^{\prime \prime} \text { N., long. } 72^{\circ} 33^{\prime} 46^{\prime \prime} \text { E., Hampshire } \\
\text { County, } 1.1 \text { miles downstream from bridge on } \\
\text { Maple Street, } 0.5 \text { miles east of North Hadley, } \\
\text { Mass. } \\
\text { Reach: A - Site } 1 \text { to site } 2 \\
\text { Reach length: } 0.7 \text { mile } \\
\text { Wetland vegetation: Forested } \\
\text { Reach: B - Site } 2 \text { to site } 3 \\
\text { Reach length: } 1.1 \text { miles } \\
\text { Wetland vegetation: Forested, scrub/shrub, and } \\
\text { emergent }\end{array}$ & $8-03-87$ \\
\hline \multirow[t]{4}{*}{$\begin{array}{l}\text { Natty Pond Brook } \\
\text { near Hubbardston, } \\
\text { Mass. }\end{array}$} & $\begin{array}{l}\text { Site } 1 \text { near } \\
\text { Hubbardston }\end{array}$ & $\begin{array}{l}\text { Lat. } 42^{\circ} 29^{\prime} 44^{\prime \prime} \text { N., long. } 72^{\circ} 01^{\prime} 24^{\prime \prime} \text { E., Worcester } \\
\text { County, on right bank at upstream side of } \\
\text { culvert on New Templeton Road, } 1.7 \text { miles } \\
\text { northwest of Hubbardston, Mass. }\end{array}$ & $6-25-86$ \\
\hline & $\begin{array}{l}\text { Site } 2 \text { near } \\
\text { Hubbardston }\end{array}$ & $\begin{array}{l}\text { Lat. } 42^{\circ} 29^{\prime} 24^{\prime \prime} \mathrm{N} . \text {, long. } 72^{\circ} 01^{\prime} 30^{\prime \prime} \mathrm{E} ., \text { Worcester } \\
\text { County, } 2,200 \text { feet downstream from } \\
\text { culvert on New Templeton Road, } 1.4 \text { miles } \\
\text { northwest of Hubbardston, Mass. }\end{array}$ & $\begin{array}{l}9-17-85 \\
6-25-86\end{array}$ \\
\hline & $\begin{array}{l}\text { Site } 3 \text { at } \\
\text { Hubbardston }\end{array}$ & $\begin{array}{l}\text { Lat. } 42^{\circ} 28^{\prime} 52^{\prime \prime} \text { N., long. } 72^{\circ} 01^{\prime} 38^{\prime \prime} \text { E., Worcester } \\
\text { County, } 1,000 \text { feet upstream from bridge on } \\
\text { Williamsville Road, } 1.0 \text { miles west of } \\
\text { Hubbardston, Mass. }\end{array}$ & $9-17-85$ \\
\hline & $\begin{array}{l}\text { Site } 4 \text { at } \\
\text { Hubbardston }\end{array}$ & $\begin{array}{l}\text { Lat. } 42^{\circ} 28^{\prime} 05^{\prime \prime} \mathrm{N}_{\text {., }} \text { long. } 72^{\circ} 01^{\prime} 14^{\prime \prime} \mathrm{E} \text {., Worcester } \\
\text { County, } 1,200 \text { feet downstream from bridge } \\
\text { on Parson Road, } 0.8 \text { miles southwest of } \\
\text { Hubbardston, Mass. }\end{array}$ & $\begin{array}{l}5-22-85 \\
8-20-85\end{array}$ \\
\hline
\end{tabular}


Appendix 1.--Study-reach location and descriptions--Continued

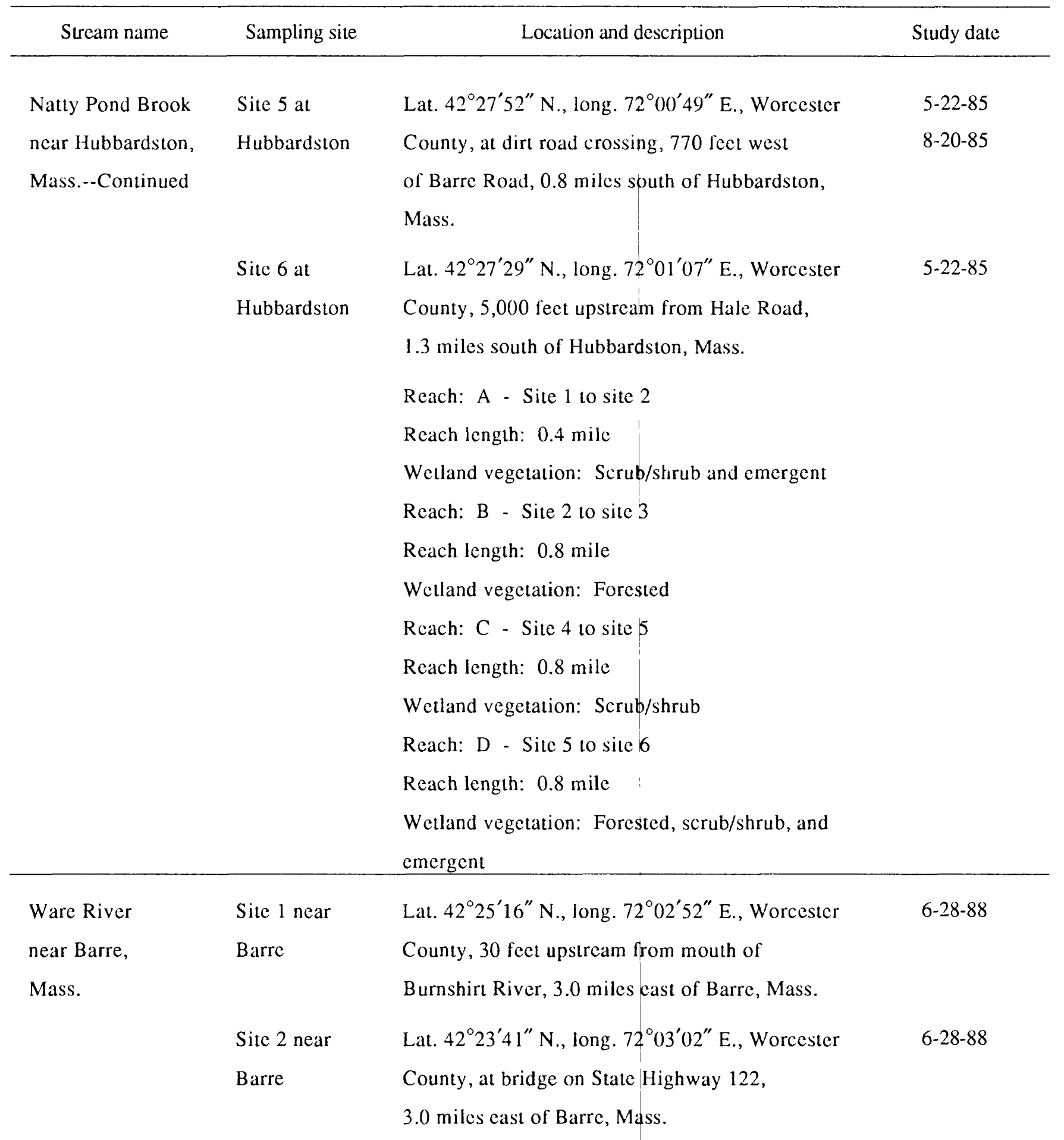


Appendix 1.--Study-reach location and descriptions--Continued

\begin{tabular}{|c|c|c|c|}
\hline Stream name & Sampling site & Location and description & Study date \\
\hline Ware River & & Reach: A - Site 1 to site 2 & \\
\hline near Barre, & & Reach length: 2.2 miles & \\
\hline Mass.--Continued & & Wetland vegetation: Scrub/shrub and emergent & \\
\hline \multirow{16}{*}{$\begin{array}{l}\text { Karner Brook } \\
\text { at South } \\
\text { Egremont, Mass. }\end{array}$} & Site 1 at & Lat. $42^{\circ} 09^{\prime} 19^{\prime \prime}$ N., long. $73^{\circ} 25^{\prime} 51^{\prime \prime}$ E., Berkshire & $10-14-88$ \\
\hline & South Egremont & County, at most easterly bridge on Mount & \\
\hline & & Washington Road, 0.8 miles southwest of South & \\
\hline & & Egremont, Mass. & \\
\hline & Site 2 at & Lat. $42^{\circ} 09^{\prime} 24^{\prime \prime}$ N., long. $73^{\circ} 25^{\prime} 45^{\prime \prime}$ E., Berkshire & $10-14-88$ \\
\hline & South Egremont & County, 0.2 miles upstream of Mill Pond, & \\
\hline & & 0.7 miles southwest of South Egremont, Mass. & \\
\hline & Site 3 at & Lat. $42^{\circ} 09^{\prime} 30^{\prime \prime}$ N., long. $73^{\circ} 25^{\prime} 20^{\prime \prime}$ E., Berkshire & $10-14-88$ \\
\hline & South Egremont & County, at outlet of Mill Pond, 0.4 miles & \\
\hline & & southwest of South Egremont, Mass. & \\
\hline & & Reach: A - Site 1 to site 2 & \\
\hline & & Reach length: 0.2 mile & \\
\hline & & Wetland vegetation: Forested & \\
\hline & & Reach: B - Site 2 to site 3 & \\
\hline & & Reach length: 0.5 mile & \\
\hline & & Wetland vegetation: Scrub/shrub and emergent & \\
\hline \multirow{7}{*}{$\begin{array}{l}\text { Batten Kill } \\
\text { near Greenwich, } \\
\text { N.Y. }\end{array}$} & Site 1 near & Lat. $43^{\circ} 05^{\prime} 30^{\prime \prime}$ N., long. $73^{\circ} 27^{\prime} 59^{\prime \prime}$ E., & $8-24-87$ \\
\hline & Greenwich & Washington County, 0.4 miles downstream & \\
\hline & & from bridge at Center Falls, 1.5 miles northeast of & \\
\hline & & Greenwich, N.Y. & \\
\hline & Site 2 at & Lat. $43^{\circ} 05^{\prime} 27^{\prime \prime}$ N., long. $73^{\circ} 29^{\prime} 45^{\prime \prime}$ E., & $8-24-87$ \\
\hline & Greenwich & $\begin{array}{l}\text { Washington County, at upper dam at } \\
\text { Greenwich, N.Y. }\end{array}$ & \\
\hline & & $\begin{array}{l}\text { Reach: A - Site } 1 \text { to site } 2 \\
\text { Reach length: } 1.7 \text { miles }\end{array}$ & \\
\hline
\end{tabular}


Appendix 1.--Study-reach location and descriptions--Continued

\begin{tabular}{|c|c|c|c|}
\hline Stream name & Sampling site & Location and description & Study date \\
\hline \multirow{15}{*}{$\begin{array}{l}\text { Hoosic River } \\
\text { near Adams, } \\
\text { Mass. }\end{array}$} & Site 1 near & Lat. $42^{\circ} 38^{\prime} 38^{\prime \prime}$ N., long. $73^{\circ} 06^{\prime} 29^{\prime \prime}$ E., Berkshire & $6-09-87$ \\
\hline & Adams & County, 0.3 miles downistream from bridge on & $6-02-88$ \\
\hline & & Lime Street, 1.2 miles north of Adams, Mass. & $8-17-88$ \\
\hline & Site 2 near & Lat. $42^{\circ} 39^{\prime} 54^{\prime \prime} \mathrm{N}_{\text {., long. }} 73^{\circ} 06^{\prime} 16^{\prime \prime} \mathrm{E}$., Berkshire & $6-09-87$ \\
\hline & Adams & County, at bridge on State Highway $8 \mathrm{~A}$, & $6-02-88$ \\
\hline & & 2.9 miles north of Adams, Mass. & $8-17-88$ \\
\hline & Site 3 near & Lat. $42^{\circ} 41^{\prime} 08^{\prime \prime} N^{\prime}$., long. $73^{\circ} 06^{\prime} 21^{\prime \prime}$ E., Berkshire & $6-09-87$ \\
\hline & Adams & County, at entrance of North Adams flood & $8-17-88$ \\
\hline & & control channel, 1.0 miles south of & \\
\hline & & North Adams, Mass. & \\
\hline & & Reach: A - Site 1 to site 2 & \\
\hline & & Reach length: 2.1 miles & \\
\hline & & Reach: B - Site 2 to site 3 & \\
\hline & & Reach length: 1.7 miles & \\
\hline & & Wetland vegetation: Forested & \\
\hline \multirow{10}{*}{$\begin{array}{l}\text { Normans Kill } \\
\text { near Westmere, } \\
\text { N.Y. }\end{array}$} & Site 1 near & Lat. $42^{\circ} 40^{\prime} 43^{\prime \prime}$ N., long. $73^{\circ} 54^{\prime} 25^{\prime \prime}$ E., Albany & $6-08-88$ \\
\hline & Westmere & County, 100 feet upstream from bridge on State & \\
\hline & & Highway $155,1.6$ miles southwest of Westmere, & \\
\hline & & N.Y., 0.5 miles southeast of Guilderland, N.Y. & \\
\hline & Site 2 near & Lat. $42^{\circ} 40^{\prime} 02^{\prime \prime}$ N., long. $73^{\circ} 53^{\prime} 48^{\prime \prime}$ E., Albany & $6-08-88$ \\
\hline & Voorheesville & County, at bridge on Normans Kill Road, & \\
\hline & & 0.1 miles upstream from Vly Creek, and 1.2 miles & \\
\hline & & northeast of Voorheesville, N.Y. & \\
\hline & & Reach: A - Site 1 to site 2 & \\
\hline & & Reach length: 1.3 miles & \\
\hline
\end{tabular}


Appendix 1.--Study-reach location and descriptions--Continued

\begin{tabular}{|c|c|c|c|}
\hline Stream name & Sampling site & Location and description & Study date \\
\hline \multirow{9}{*}{$\begin{array}{l}\text { Cocymans Creek } \\
\text { near Cocymans, } \\
\text { N.Y. }\end{array}$} & Site 1 near & Lat. $42^{\circ} 30^{\prime} 47^{\prime \prime} \mathrm{N}$., long. $73^{\circ} 48^{\prime} 31^{\prime \prime}$ E., Albany & $9-29-87$ \\
\hline & Selkirk & County, at bridge on Pictovia Road, & \\
\hline & & 1.4 miles southwest of Selkirk, N.Y. & \\
\hline & Site 2 near & Lat. $42^{\circ} 29^{\prime} 33^{\prime \prime}$ N., long. $73^{\circ} 48^{\prime} 08^{\prime \prime}$ E., Albany & $9-29-87$ \\
\hline & Coeymans & County, just downstream from bridge on & \\
\hline & & the Thomas E. Dewey Thruway, 1.3 miles & \\
\hline & & northwest of Coeymans, N.Y. & \\
\hline & & Reach: A - Site 1 to site 2 & \\
\hline & & Reach length: 2.5 miles & \\
\hline
\end{tabular}

\section{Claverack Creek Site 1 at}

at Hudson, N.Y. Hudson

Site 2 at

Stattville

Lat. $42^{\circ} 15^{\prime} 17^{\prime \prime}$ N., long. $73^{\circ} 45^{\prime} 17^{\prime \prime}$ E., Columbus

$6-28-88$

County, at bridge on State Highway 66 ,

at Hudson, N.Y.

Lat. $42^{\circ} 17^{\prime} 12^{\prime \prime}$ N., long. $73^{\circ} 44^{\prime} 14^{\prime \prime}$ E., Columbus

6-28-88

County, just upstream from dam at State

Highway 401 at Stattville, N.Y.

Reach: A - Site 1 to site 2

Reach length: 2.5 miles

West Branch

Delaware River at

Deposit, N.Y.
Site 1 at

Deposit

Site 2 at

Hale Eddy
Lat. $42^{\circ} 02^{\prime} 49^{\prime \prime}$ N., long. $75^{\circ} 25^{\prime} 16^{\prime \prime}$ E., Delaware

10-22-86

County, 0.7 miles downstream from Oquaga

Creek, 1.0 miles south of Deposit, N.Y.

Lat. $42^{\circ} 00^{\prime} 10^{\prime \prime}$ N., long. $75^{\circ} 23^{\prime} 02^{\prime \prime}$ E., Delaware

$10-22-86$

County, 9.0 miles upstream from confluence

of East and West Branches of Delaware River near Hancock, at Highway Bridge at Hale Eddy, N.Y. 
Appendix 1.--Study-reach location and descriptions--Continued

\begin{tabular}{|c|c|c|c|}
\hline Stream name & Sampling site & Location and description & Study date \\
\hline West Branch & & Reach: A - Site 1 to site 2 & \\
\hline Delaware River & & Reach length: 3.9 miles & \\
\hline at Deposit, N.Y.-- & & Wetland vegetation: Forested & \\
\hline \multicolumn{4}{|l|}{ Continued } \\
\hline \multirow{11}{*}{$\begin{array}{l}\text { Susquehanna } \\
\text { River at } \\
\text { Phoenix Mills, } \\
\text { N.Y. }\end{array}$} & Site 1 near & Lat. $42^{\circ} 40^{\prime} 43^{\prime \prime}$ N., long. $74^{\circ} 56^{\prime} 16^{\prime \prime}$ E., Otsego & $8-09-88$ \\
\hline & Cooperstown & County, at bridge on private dirt road, & \\
\hline & & 0.7 miles downstream from Red Creek, & \\
\hline & & 0.9 miles south of Cooperstown, N.Y., Corporate & \\
\hline & & boundary & \\
\hline & Site 2 at & Lat. $42^{\circ} 40^{\prime} 02^{\prime \prime}$ N., long. $74^{\circ} 56^{\prime} 45^{\prime \prime}$ E., Otsego & $8-09-88$ \\
\hline & Phoenix Mills & County, at bridge on road 0.1 miles west of & \\
\hline & & Phoenix Mills, N.Y., 0.8 miles northwest of & \\
\hline & & Hyde Park, N.Y. & \\
\hline & & Reach: A - Site 1 to site 2 & \\
\hline & & Reach length: 1.3 miles & \\
\hline \multirow{9}{*}{$\begin{array}{l}\text { Canisteo River } \\
\text { at Hornell, N.Y. }\end{array}$} & Site 1 at & Lat. $42^{\circ} 18^{\prime} 20^{\prime \prime}$ N., long. $77^{\circ} 39^{\prime} 18^{\prime \prime}$ E., Steuben & $9-26-88$ \\
\hline & Hornell & County, at bridge on East Street, 0.9 miles & \\
\hline & & south of Hornell, N.Y. & \\
\hline & Site 2 at & Lat. $42^{\circ} 17^{\prime} 10^{\prime \prime}$ N., long. $77^{\circ} 37^{\prime} 29^{\prime \prime}$ E., Steuben & $9-26-88$ \\
\hline & Canisteo & County, at bridge on town road, 0.3 miles west & \\
\hline & & upstream of Cunningham Creek, 1.5 miles & \\
\hline & & northwest of Canisteo, N.Y. & \\
\hline & & Reach: A - Site 1 to site 2 & \\
\hline & & Reach length: 2.4 miles & \\
\hline
\end{tabular}


Appendix 1.--Study-reach location and descriptions--Continued

\begin{tabular}{|c|c|c|c|}
\hline Stream name & Sampling site & Location and description & Study date \\
\hline \multirow{10}{*}{$\begin{array}{l}\text { Caughdenoy Creek } \\
\text { near Caughdenoy, } \\
\text { N.Y.--Continued }\end{array}$} & Site 1 near & Lat. $43^{\circ} 17^{\prime} 54^{\prime \prime} \mathrm{N}$., long. $76^{\circ} 12^{\prime} 19^{\prime \prime}$ E., Oswego & $6-13-88$ \\
\hline & Caughdenoy & County, 0.2 miles downstream of bridge on & \\
\hline & & State Highway $49,0.3$ miles southeast of & \\
\hline & & McMahon Corners, 1.3 miles north of & \\
\hline & & Caughdenoy, N.Y. & \\
\hline & Site 2 near & Lat. $43^{\circ} 16^{\prime} 42^{\prime \prime}$ N., long. $76^{\circ} 11^{\prime} 39^{\prime \prime}$ E., Oswego & $6-13-88$ \\
\hline & Caughdenoy & County, at culvert on Fuller Road, 0.7 miles & \\
\hline & & northwest of Caughdenoy, N.Y. & \\
\hline & & Reach: A - Site 1 to site 2 & \\
\hline & & Reach length: 0.7 mile & \\
\hline \multirow{13}{*}{$\begin{array}{l}\text { South Sandy } \\
\text { Creek near } \\
\text { Ellisburg, N.Y. }\end{array}$} & Site 1 near & Lat. $43^{\circ} 43^{\prime} 17^{\prime \prime}$ N., long. $76^{\circ} 09^{\prime} 25^{\prime \prime}$ E., Jefferson & $6-15-88$ \\
\hline & Ellisburg & County, 1.0 miles upstream from Kibling Creck, & \\
\hline & & 1.3 miles southeast of Ellisburg, N.Y. & \\
\hline & Site 2 near & Lat. $43^{\circ} 42^{\prime} 55^{\prime \prime}$ N., long. $76^{\circ} 10^{\prime} 04^{\prime \prime}$ E., Jefferson & 6-15-88 \\
\hline & Ellisburg & County, 500 feet upstream from Kibling Creek, & \\
\hline & & 2.0 miles southeast of Ellisburg, N.Y. & \\
\hline & Site 3 near & Lat. $43^{\circ} 42^{\prime} 55^{\prime \prime}$ N., long. $76^{\circ} 10^{\prime} 04^{\prime \prime}$ E., Jefferson & $6-15-88$ \\
\hline & Ellisburg & County, 0.7 miles downstream from Kibling & \\
\hline & & Creck, 2.6 miles southeast of Ellisburg, N.Y. & \\
\hline & & Reach: A - Site 1 to site 2 & \\
\hline & & Reach length: 1.0 mile & \\
\hline & & Reach: B - Site 2 to site 3 & \\
\hline & & Reach length: 0.7 mile & \\
\hline
\end{tabular}


Appendix 1.--Study-reach location and descriptions--Continued

\begin{tabular}{|c|c|c|c|}
\hline Stream name & Sampling site & Location and description & Study date \\
\hline $\begin{array}{l}\text { Indian River } \\
\text { at Kelsey Bridge, } \\
\text { N.Y. }\end{array}$ & $\begin{array}{l}\text { Site } 2 \text { at } \\
\text { Kelsey Bridge }\end{array}$ & $\begin{array}{l}\text { Lat. } 44^{\circ} 08^{\prime} 41^{\prime \prime} \text { N., long. } 75^{\circ} 47^{\prime} 22^{\prime \prime} \text { E., Jefferson } \\
\text { County, } 0.1 \text { miles downstream from Joachin } \\
\text { Bridge, } 0.1 \text { miles northeast of River Road, } \\
4.0 \text { miles northeast of Evans Mills, N.Y. } \\
\text { Lat. } 44^{\circ} 10^{\prime} 29^{\prime \prime} \text { N., long. } 75^{\circ} 47^{\prime} 00^{\prime \prime} \text { E., Jefferson } \\
\text { County, at bridge on River Road at Kelsey } \\
\text { Bridge, } 2.9 \text { miles south of Theresa, N.Y. } \\
\text { Reach: A - Site } 1 \text { to site } 2 \\
\text { Reach length: } 1.8 \text { miles }\end{array}$ & $6-02-87$ \\
\hline
\end{tabular}


Appendix 2.--Reach characteristics, time-of-travel characteristics, and measured reaeration coefficients from 42 tracer studies

[ $\mathrm{ft}$, foot; $\mathrm{ft} / \mathrm{s}$, foot per second; $\mathrm{ft}^{3} / \mathrm{s}$, cubic foot per second; $\mathrm{ft} / \mathrm{ft}$, foot per foot; channel elevation is in feet above sea level]

\begin{tabular}{|c|c|c|c|c|c|c|c|c|c|}
\hline Reach & $\begin{array}{c}\text { Study } \\
\text { date }\end{array}$ & $\begin{array}{l}\text { Reach } \\
\text { descrip- } \\
\text { tor }^{1}\end{array}$ & $\begin{array}{c}\text { Dis- } \\
\text { charge } \\
\left(\mathrm{ft}^{3} / \mathrm{s}\right)\end{array}$ & $\begin{array}{l}\text { Water- } \\
\text { surface } \\
\text { slope } \\
(\mathrm{ft} / \mathrm{ft})\end{array}$ & $\begin{array}{l}\text { Mean } \\
\text { streamflow } \\
\text { velocity } \\
(\mathrm{ft} / \mathrm{s})\end{array}$ & $\begin{array}{l}\text { Average } \\
\text { wind- } \\
\text { speed } \\
(\mathrm{f} \mathrm{u} / \mathrm{s})\end{array}$ & $\begin{array}{l}\text { Resultant wind } \\
\text { velocity parallel to } \\
\text { channel azimuth and } \\
\text { corrected for mean } \\
\text { sheltering angle } \\
(\mathrm{fl} / \mathrm{s})\end{array}$ & $\begin{array}{c}\text { Mean } \\
\text { depth } \\
(\mathrm{ft})\end{array}$ & $\begin{array}{c}\text { Mean } \\
\text { width } \\
\text { (ft) }\end{array}$ \\
\hline
\end{tabular}

\section{Beaver Brook near Littleton, Mass.}
A $\quad 6-17-86$
L
$\begin{array}{lll}5.6 & 0.00035 & 0.03\end{array}$
13.5
11.8
3.3
65

Assabet River near Westborough, Mass.

$\begin{array}{llllllllll}\text { A } & 5-13-86 & \text { L } & 8.3 & .00023 & .29 & 10.6 & .1 & 1.4 & 20 \\ \text { A } & 8-05-86 & \text { L } & 3.0 & .00020 & .12 & 14.2 & 13.9 & 1.2 & 20 \\ \text { A } & 10-28-86 & \text { L } & 1.6 & .00012 & .08 & 14.8 & 3.2 & 1.0 & 20 \\ \text { B } & 8-05-86 & \text { L } & 3.0 & .00003 & .50 & 13.2 & 2.5 & .2 & 25\end{array}$

Sudbury River near Wayland, Mass.
A $\quad 11-16-8$
L
$76.3 \quad .31$
$00005 \quad .31$
21.7
21.7
$5.0 \quad 98$

Ipswich River near Topsfield, Mass.

$\begin{array}{llllllllll}\text { A } & 6-23-87 & \text { L } & 33.7 & .00009 & .23 & 19.8 & 5.6 & 4.7 & 31 \\ \text { B } & 6-23-87 & \text { I } & 37.4 & .00034 & .05 & 19.2 & 8.0 & 9.0 & 81\end{array}$

Taunton River near Bridgewater, Mass.
A $\quad 5-03-88$
$\begin{array}{lll}\mathrm{L} & 315.8 \quad .00006\end{array}$
.62
19.2
17.6
$8.7 \quad 59$
A $\quad 8-23-88$
L
$\begin{array}{lll}45.5 & .00003 \quad .15\end{array}$
18.8
18.4
$4.9 \quad 61$ 
Appendix 2.--Reach characteristics, time-of-travel characteristics, and measured reaeration coefficients from 42 tracer studies--Continued

\begin{tabular}{|c|c|c|c|c|c|c|c|c|c|}
\hline Reach & $\begin{array}{c}\text { Study } \\
\text { date }\end{array}$ & $\begin{array}{l}\text { Reach } \\
\text { descrip- } \\
\text { tor }^{1}\end{array}$ & $\begin{array}{c}\text { Dis- } \\
\text { charge } \\
\left(\mathrm{ft}^{3} / \mathrm{s}\right)\end{array}$ & $\begin{array}{l}\text { Water- } \\
\text { surface } \\
\text { slope } \\
(\mathrm{f} u \mathrm{ft})\end{array}$ & $\begin{array}{c}\text { Mean } \\
\text { streamflow } \\
\text { velocity } \\
\text { (fu/s) }\end{array}$ & $\begin{array}{l}\text { Average } \\
\text { wind- } \\
\text { speed } \\
(\mathrm{f} / \mathrm{s})\end{array}$ & $\begin{array}{l}\text { Resultant wind } \\
\text { velocity parallel to } \\
\text { channel azimuth and } \\
\text { corrected for mean } \\
\text { sheltering angle } \\
(\mathrm{ft} / \mathrm{s})\end{array}$ & $\begin{array}{c}\text { Mean } \\
\text { depth } \\
(\mathrm{ft})\end{array}$ & $\begin{array}{c}\text { Mean } \\
\text { width } \\
(\mathrm{ft})\end{array}$ \\
\hline
\end{tabular}

French River near Oxford, Mass.

$\begin{array}{llllllllll}\text { A } & 6-21-88 & \text { L } & 6.6 & .00073 & .19 & 13.8 & 7.5 & 1.6 & 22 \\ \text { A } & 9-23-88 & \text { L } & 2.0 & .00070 & .06 & 14.1 & 1.2 & 1.9 & 19 \\ \text { B } & 9-23-88 & \text { L } & 2.0 & .00033 & .01 & 15.8 & 6.8 & 7.0 & 28 \\ \text { C } & 10-21-87 & \text { I } & 20.7 & .00020 & .20 & 14.2 & .1 & 2.3 & 46 \\ \text { C } & 6-21-88 & \text { I } & 8.0 & .00021 & .24 & 13.5 & 7.9 & .7 & 46\end{array}$

Otter River near Gardner, Mass.

\begin{tabular}{llllll|llll} 
A & $5-19-87$ & $\mathrm{H}$ & 33.3 & .00336 & .32 & 9.4 & 2.0 & 3.0 & 35
\end{tabular}

Mill River near Amherst, Mass.

$\begin{array}{llllllllll}\text { A } & 8-03-87 & \text { L } & 14.4 & .00020 & .30 & 12.5 & 10.5 & 2.0 & 25 \\ \text { B } & 8-03-87 & \text { L } & 14.4 & .00026 & .48 & 12.5 & 11.5 & 1.1 & 28\end{array}$

Natty Pond Brook near Hubbardston, Mass.

$\begin{array}{lrlrrrrrrr}\text { A } & 6-25-86 & \text { L } & 2.0 & .00001 & .03 & 13.8 & 2.0 & 3.6 & 19 \\ \text { B } & 9-17-85 & \text { H } & 1.1 & .00601 & .09 & 10.1 & 1.7 & 1.0 & 13 \\ \text { C } & 5-22-85 & \text { L } & 12.0 & .00053 & .25 & 12.6 & 1.0 & 2.1 & 23 \\ \text { C } & 8-20-85 & \text { L } & 3.2 & .00005 & .08 & 7.3 & 4.0 & 1.6 & 24 \\ \text { D } & 5-22-85 & \text { L } & 12.4 & .00087 & .17 & 11.0 & 10.6 & 2.4 & 31\end{array}$


Appendix 2.--Reach characteristics, time-of-travel characteristics, and measured reaeration coefficients from 42 tracer studies--Continued

\begin{tabular}{|c|c|c|c|c|c|c|c|c|c|}
\hline Reach & $\begin{array}{c}\text { Study } \\
\text { date }\end{array}$ & $\begin{array}{l}\text { Reach } \\
\text { descrip- } \\
\text { tor }^{1}\end{array}$ & $\begin{array}{l}\text { Dis- } \\
\text { cliarge } \\
\left(\mathrm{ft}^{3} / \mathrm{s}\right)\end{array}$ & $\begin{array}{l}\text { Water- } \\
\text { surface } \\
\text { slope } \\
(\mathrm{f} u \mathrm{ft})\end{array}$ & $\begin{array}{c}\text { Mean } \\
\text { streamflow } \\
\text { velocity } \\
(\mathrm{fl} / \mathrm{s})\end{array}$ & $\begin{array}{l}\text { Average } \\
\text { wind- } \\
\text { speed } \\
(\mathrm{f} / \mathrm{s})\end{array}$ & $\begin{array}{l}\text { Resultant wind } \\
\text { velocity parallel to } \\
\text { channel azimuth and } \\
\text { corrected for mean } \\
\text { sheltering angle } \\
(\mathrm{ft} / \mathrm{s})\end{array}$ & $\begin{array}{c}\text { Mean } \\
\text { depth } \\
(\mathrm{ft})\end{array}$ & $\begin{array}{c}\text { Mean } \\
\text { width } \\
(\mathrm{ft})\end{array}$ \\
\hline
\end{tabular}

Ware River near Barre, Mass.

$\begin{array}{lllllllll}\text { A } & 6-28-88 & \text { L } & 27.4 & 0.00003 & 0.07 & 13.5 & 13.5 & 4.5\end{array}$

Karner Brook at South Egremont, Mass.

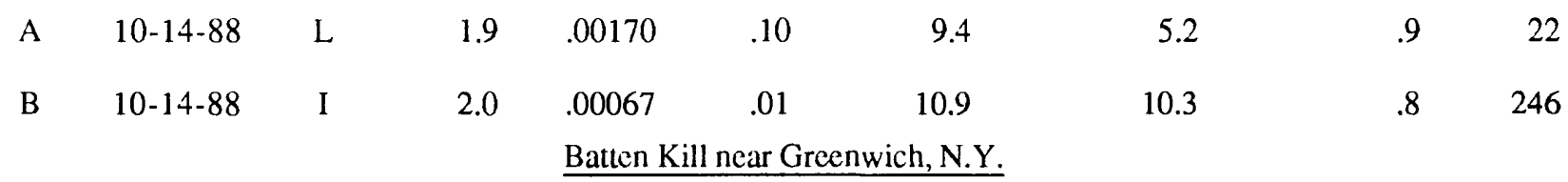

$\begin{array}{llllllllll}\text { A } & 8-24-87 & \text { I } & 181.1 & .00026 & .37 & 10.1 & 9.0 & 3.8 & 128\end{array}$

Hoosic River ncar Adams, Mass.

$\begin{array}{llllllllll}\text { A } & 6-09-87 & \text { H } & 58.5 & .00371 & .86 & 20.7 & 14.1 & 1.6 & 42 \\ \text { A } & 6-02-88 & \text { H } & 114.9 & .00325 & 1.34 & 12.0 & .9 & 2.4 & 36 \\ \text { A } & 8-17-88 & \text { H } & 38.1 & .00326 & .72 & 7.8 & .7 & 1.5 & 35 \\ \text { B } & 6-09-87 & \text { I } & 61.6 & .00092 & .66 & 20.7 & 12.1 & 2.5 & 37 \\ \text { B } & 8-17-88 & \text { I } & 44.8 & .00092 & .60 & 10.3 & .8 & 2.6 & 29\end{array}$

Normans Kill near Westmere, N.Y.
A $\quad 6-08-88$
L
$15.9 \quad 00124$
.38
12.9
1.4
.8
50

Coeymans Creek near Coeymans, N.Y.
A $\quad 9-29-87 \quad$ L
19.8
20.2
18.7
1.6
31

Claverack Creck at Hudson, N.Y.
A $\quad 6-28-88$
I
$30.0 \quad .00049$
.05
14.1
5.1
5.2
128 
Appendix 2.--Reach characteristics, time-of-travel characteristics, and measured reaeration coefficients from 42 tracer studies--Continued

\begin{tabular}{|c|c|c|c|c|c|c|c|c|c|}
\hline Reach & $\begin{array}{l}\text { Study } \\
\text { date }\end{array}$ & $\begin{array}{l}\text { Reach } \\
\text { descrip- } \\
\text { tor }^{1}\end{array}$ & $\begin{array}{l}\text { Dis- } \\
\text { charge } \\
\left(\mathrm{ft}^{3} / \mathrm{s}\right)\end{array}$ & $\begin{array}{c}\text { Water- } \\
\text { surface } \\
\text { slope } \\
(\mathrm{ft} / \mathrm{ft})\end{array}$ & $\begin{array}{c}\text { Mean } \\
\text { streamflow } \\
\text { velocity } \\
(\mathrm{f} / \mathrm{s})\end{array}$ & $\begin{array}{l}\text { Average } \\
\text { wind- } \\
\text { speed } \\
(\mathrm{f} / \mathrm{s})\end{array}$ & $\begin{array}{l}\text { Resultant wind } \\
\text { velocity parallel to } \\
\text { channel azimuth and } \\
\text { corrected for mean } \\
\text { sheltering angle } \\
(\mathrm{fu} / \mathrm{s})\end{array}$ & $\begin{array}{c}\text { Mean } \\
\text { depth } \\
(\mathrm{ft})\end{array}$ & $\begin{array}{c}\text { Mean } \\
\text { width } \\
(\mathrm{ft})\end{array}$ \\
\hline \multicolumn{10}{|c|}{ West Branch Delaware River near Deposit, N.Y. } \\
\hline A & $10-22-86$ & $\mathrm{~L}$ & 104.5 & .00108 & .56 & 11.0 & 5.7 & .9 & 201 \\
\hline \multicolumn{10}{|c|}{$\underline{\text { Susquehanna River at Phoenix Mills, N.Y. }}$} \\
\hline A & $8-09-88$ & $\mathrm{~L}$ & 24.1 & .00041 & .25 & 7.3 & 3.3 & 2.5 & 39 \\
\hline \multicolumn{10}{|c|}{ Canisteo River at Hornell, N.Y. } \\
\hline A & $9-26-88$ & $\mathrm{~L}$ & 20.2 & .00040 & .22 & 13.6 & 13.5 & 2.7 & 34 \\
\hline \multicolumn{10}{|c|}{ Caughdenoy Creek near Caughdenoy, N.Y. } \\
\hline A & $6-13-88$ & $\mathrm{~L}$ & 2.1 & .00003 & .04 & 8.1 & 2.4 & 1.6 & 29 \\
\hline \multicolumn{10}{|c|}{ South Sandy Creek near Ellisburg, N.Y. } \\
\hline A & $6-15-88$ & $\mathrm{~L}$ & 14.9 & .00116 & .31 & 9.3 & .5 & .7 & 48 \\
\hline B & $6-15-88$ & $\mathrm{~L}$ & 15.1 & .00010 & .14 & 8.7 & 2.7 & 1.6 & 67 \\
\hline \multicolumn{10}{|c|}{ Indian River at Kelsey Bridge, N.Y. } \\
\hline A & $6-02-87$ & $\mathrm{~L}$ & 137.3 & .00006 & .17 & 15.6 & 11.8 & 8.2 & 97 \\
\hline
\end{tabular}


Appendix 2.--Reach characteristics, time-of-travel characteristics, and measured reaeration coefficients from 42 tracer studies--Continued

[Pt-Co, platinum-cobalt; mg/L, milligrams per liter; $\mu \mathrm{S} / \mathrm{cm}$, microsiemens per centimeter; ${ }^{\circ} \mathrm{C}$, degrees Celsius]

\begin{tabular}{|c|c|c|c|c|c|c|c|c|}
\hline Reach & & Reach & Channel & Channel & Mean & Color & $\begin{array}{l}\text { Total } \\
\text { organic }\end{array}$ & $\begin{array}{l}\text { Methylene- Specific } \\
\text { blue active- conductance }\end{array}$ \\
\hline & date & $\begin{array}{l}\text { descrip- } \\
\text { tor }^{1}\end{array}$ & $\begin{array}{l}\text { azimuth } \\
\text { (degree) }\end{array}$ & $\begin{array}{l}\text { elevation } \\
(\mathrm{ft})\end{array}$ & $\begin{array}{l}\text { sheltering } \\
\text { angle } \\
\text { (degree) }\end{array}$ & $(\mathrm{Pt}-\mathrm{Co})$ & $\begin{array}{l}\text { carbon } \\
\text { concen- } \\
\text { tration } \\
(\mathrm{mg} / \mathrm{L})\end{array}$ & $\begin{array}{cc}\text { substances } & (\mu \mathrm{S} / \mathrm{cm} \\
\text { concen- } & \left.\text { at } 25^{\circ} \mathrm{C}\right) \\
\text { tration } & \\
(\mathrm{mg} / \mathrm{L}) & \end{array}$ \\
\hline
\end{tabular}

$\underline{\text { Beaver Brook near Littleton, Mass. }}$

$\begin{array}{llllllllll}\text { A } & 6-17-86 & \text { L } & 22.5 & 220 & 71.9 & 160 & 20 & 0.07 & 183\end{array}$

Assabet River near Westborough, Mass.

$\begin{array}{llllllllll}\text { A } & 5-13-86 & \text { L } & 339.5 & 269 & 67.0 & 30 & 15 & .13 & 234 \\ \text { A } & 8-05-86 & \text { L } & 339.5 & 269 & 67.0 & 50 & 13 & .12 & 277 \\ \text { A } & 10-28-86 & \text { L } & 339.5 & 269 & 67.0 & 35 & 9.4 & .13 & 360 \\ \text { B } & 8-05-86 & \text { L } & 58.0 & 269 & 111.5 & 60 & 19 & .54 & 336\end{array}$

Sudbury River near Wayland, Mass.
A $\quad 11-16-87$
$\mathrm{L}$
29.5
$112 \quad 165.8$
8
$5.9 \quad .05$
390

Ipswich River near Topsfield, Mass.

$\begin{array}{lrrrrrrrrr}\text { A } & 6-23-87 & \text { L } & 9.5 & 49 & 74.2 & 44 & 6.7 & .07 & 227 \\ \text { B } & 6-23-87 & \text { I } & 68.0 & 49 & 85.7 & 44 & 6.7 & .07 & 227\end{array}$

Taunton River near Bridgewater, Mass.

$\begin{array}{llllllllll}\text { A } & 5-03-88 & \mathrm{~L} & 41.5 & 13 & 72.2 & 58 & 10 & .13 & 190 \\ \text { A } & 8-23-88 & \mathrm{~L} & 41.5 & 13 & 75.0 & 51 & 9.5 & .14 & 357\end{array}$


Appendix 2.--Reach characteristics, time-of-travel characteristics, and measured reaeration coefficients from 42 tracer studies--Continued

\begin{tabular}{|c|c|c|c|c|c|c|c|c|}
\hline Reach & Study & Reach & Channel & Channel & Mean & Color & $\begin{array}{l}\text { Total } \\
\text { organic }\end{array}$ & $\begin{array}{l}\text { Methylene- Specific } \\
\text { blue active- conductance }\end{array}$ \\
\hline & date & $\begin{array}{l}\text { descrip- } \\
\text { tor }^{1}\end{array}$ & $\begin{array}{l}\text { azimuth } \\
\text { (degrec) }\end{array}$ & $\begin{array}{l}\text { elevation } \\
\text { (ft) }\end{array}$ & $\begin{array}{l}\text { sheltering } \\
\text { angle } \\
\text { (degree) }\end{array}$ & $(\mathrm{Pt}-\mathrm{Co})$ & $\begin{array}{l}\text { carbon } \\
\text { concen- } \\
\text { tration } \\
(\mathrm{mg} / \mathrm{L})\end{array}$ & $\begin{array}{cc}\text { substances } & (\mu \mathrm{S} / \mathrm{cm} \\
\text { concen- } & \left.\text { at } 25^{\circ} \mathrm{C}\right) \\
\text { tration } & \\
(\mathrm{mg} / \mathrm{L}) & \end{array}$ \\
\hline
\end{tabular}

French River near Oxford, Mass.

$\begin{array}{llllllllll}\text { A } & 6-21-88 & \text { L } & 35.5 & 472 & 43.8 & 35 & 5.6 & .04 & 153 \\ \text { A } & 9-23-88 & \text { L } & 35.5 & 472 & 50.7 & 16 & 6.2 & .04 & 157 \\ \text { B } & 9-23-88 & \text { L } & 339.0 & 469 & 98.9 & 16 & 6.2 & .04 & 153 \\ \text { C } & 10-21-87 & \text { I } & 354.5 & 469 & 86.4 & 37 & 8.3 & .03 & 137 \\ \text { C } & 6-21-88 & \text { I } & 354.5 & 469 & 110.8 & 35 & 5.6 & .04 & 155\end{array}$

Otter River near Gardner, Mass.
A $\quad 5-19-87$
$\mathrm{H} \quad 302.0$
896
78.5
110
22
.09
165

Mill River near Amherst, Mass.
A $\quad 8-03-87$
L $\quad 75.5$
135
45.0
5.9
.06
187
B $\quad 8-03-87$
L $\quad 297.0$
131
$39.6 \quad 13$
$5.9 \quad .06$
187

Natty Pond Brook near Hubbardston, Mass.

\begin{tabular}{lrlrrr|rrrr} 
A & $6-25-86$ & L & 14.0 & 922 & 131.3 & 20 & 3.1 & .05 & 37 \\
B & $9-17-85$ & H & 3.0 & 909 & 55.0 & 25 & 12 & .03 & 35 \\
C & $5-22-85$ & L & 60.0 & 879 & 137.3 & 75 & 6 & .05 & 45 \\
C & $8-20-85$ & L & 60.0 & 876 & 137.3 & 300 & 6.5 & .06 & 49 \\
D & $5-22-85$ & L & 305.0 & 876 & 138.5 & 75 & 6 & .05 & 45
\end{tabular}


Appendix 2.--Reach characteristics, time-of-travel characteristics, and measured reaeration coefficients from 42 tracer studies--Continued

\begin{tabular}{|c|c|c|c|c|c|c|c|c|}
\hline Reach & Study & Reach & Channel & Channel & Mean & Color & $\begin{array}{l}\text { Total } \\
\text { organic }\end{array}$ & $\begin{array}{l}\text { Methylene- Specific } \\
\text { blue active- conductance }\end{array}$ \\
\hline & date & $\begin{array}{l}\text { descrip- } \\
\text { tor }^{1}\end{array}$ & $\begin{array}{l}\text { azimuth } \\
\text { (degree) }\end{array}$ & $\begin{array}{l}\text { elevation } \\
\quad(\mathrm{ft})\end{array}$ & $\begin{array}{l}\text { sheltering } \\
\text { angle } \\
\text { (degree) }\end{array}$ & (Pl-Co) & $\begin{array}{l}\text { carbon } \\
\text { concen- } \\
\text { tration } \\
(\mathrm{mg} / \mathrm{L})\end{array}$ & $\begin{array}{cc}\text { substances } & (\mu \mathrm{S} / \mathrm{cm} \\
\text { concen- } & \left.\text { at } 25^{\circ} \mathrm{C}\right) \\
\text { tration } & \\
(\mathrm{mg} / \mathrm{L}) & \end{array}$ \\
\hline
\end{tabular}

\section{Ware River near Barre}
A $\quad 6-28-88$
L
6.0
686
$120.0 \quad 100$
$11 \quad 0.04$
58

$\underline{\text { Karner Brook at South Egremont, Mass. }}$

$\begin{array}{llllllllll}\text { A } & 10-14-88 & \text { L } & 42.0 & 732 & 125.0 & 5 & 2 & .02 & 320 \\ \text { B } & 10-14-88 & \text { I } & 69.0 & 728 & 120.0 & 5 & 2 & .02 & 320\end{array}$

Batten Kill near Greenwich, N.Y.

$\begin{array}{llllllllll}\text { A } & 8-24-87 & \text { I } & 266.5 & 341 & 101.0 & 18 & 2.8 & .02 & 226\end{array}$

$\underline{\text { Hoosic River near Adams, Mass. }}$

$\begin{array}{llllllllll}\text { A } & 6-09-87 & \text { H } & 7.0 & 725 & 70.6 & 4 & 3 & .03 & 294 \\ \text { A } & 6-02-88 & \text { H } & 7.0 & 725 & 70.0 & 4 & 2.9 & .04 & 240 \\ \text { A } & 8-17-88 & \text { H } & 7.0 & 725 & 93.8 & 2 & 3.1 & .03 & 307 \\ \text { B } & 6-09-87 & \text { I } & 358.5 & 702 & 63.0 & 4 & 3 & .03 & 294 \\ \text { B } & 8-17-88 & \text { I } & 358.5 & 702 & 86.9 & 2 & 3.1 & .03 & 376\end{array}$

Normans Kill near Westmere, N.Y.
A $\quad 6-08-88$
L $\quad 149.0$
131
$44.0 \quad 20$
$4.8 \quad .02$
603

Coeymans Creek near Cocymans, N.Y.
A $\quad 9-29-87$
L $\quad 166.0$
98
25.0
15
$3 \quad .02$
647 
Appendix 2.--Reach characteristics, time-of-travel characteristics, and measured reaeration coefficients from 42 tracer studies--Continued

\begin{tabular}{|c|c|c|c|c|c|c|c|c|}
\hline Reach & Study & Reach & Channel & Channel & Mean & Color & $\begin{array}{l}\text { Total } \\
\text { organic }\end{array}$ & $\begin{array}{l}\text { Methylene- Specific } \\
\text { blue active- conductance }\end{array}$ \\
\hline & date & $\begin{array}{l}\text { descrip- } \\
\text { tor }^{1}\end{array}$ & $\begin{array}{l}\text { azimuth } \\
\text { (degree) }\end{array}$ & $\begin{array}{c}\text { elevation } \\
\text { (ft) }\end{array}$ & $\begin{array}{l}\text { sheltering } \\
\text { angle } \\
\text { (degree) }\end{array}$ & $(\mathrm{Pt}-\mathrm{Co})$ & $\begin{array}{l}\text { carbon } \\
\text { concen- } \\
\text { tration } \\
(\mathrm{mg} / \mathrm{L})\end{array}$ & $\begin{array}{cc}\text { substances } & (\mu \mathrm{S} / \mathrm{cm} \\
\text { concen- } & \left.\text { at } 25^{\circ} \mathrm{C}\right) \\
\text { tration } & \\
(\mathrm{mg} / \mathrm{L}) & \end{array}$ \\
\hline
\end{tabular}

Claverack Creck at Hudson, N.Y.
A $\quad 6-28-88$
I
42.0
151
93.0
20
$4.6 \quad .02$
317

West Branch Delaware River near Deposit, N.Y.
A $\quad 10-22-86$
L $\quad 148.0$
981
140.0
18
1.4
.07

Susquehanna River at Phoenix Mills, N.Y.
A $\quad 8-09-88$
L $\quad 206.0$
1,181
53.0
15
$2.4 \quad .02$

Canisteo River at Hornell, N.Y.

$\begin{array}{llllllllll}\text { A } & 9-26-88 & \text { L } & 130.0 & 203 & 44.0 & 20 & 3.4 & .02 & 617\end{array}$

Caughdenoy Creek near Caughdenoy, N.Y.
A $\quad 6-13-88$
L $\quad 180.0$
381
$126.0 \quad 11$
15.3
.02

South Sandy Creek near Ellisburg, N.Y.

$\begin{array}{llllllllll}\text { A } & 6-15-88 & \text { L } & 234.5 & 180 & 31.0 & 20 & 5 & .02 & 287 \\ \text { B } & 6-15-88 & \text { L } & 241.0 & 177 & 41.0 & 20 & 5 & .02 & 287\end{array}$

Indian River at Kclsey Bridge, N.Y.

\begin{tabular}{llllllllll} 
A & $6-02-87$ & $\mathrm{~L}$ & 8.0 & 390 & 120.0 & 45 & 5.6 & .02 & 154 \\
\hline
\end{tabular}


Appendix 2.--Reach characteristics, time-of-travel characteristics, and measured reaeration coefficients from 42 tracer studies--Continued

[d, day; h, hours]

\begin{tabular}{|c|c|c|c|c|c|c|c|c|c|}
\hline \multirow[b]{2}{*}{ Reach } & \multirow[b]{2}{*}{$\begin{array}{l}\text { Study } \\
\text { date }\end{array}$} & \multirow[b]{2}{*}{$\begin{array}{l}\text { Reach } \\
\text { descrip- } \\
\text { tor }^{1}\end{array}$} & \multirow[b]{2}{*}{$\begin{array}{l}\text { Suspended- } \\
\text { solids } \\
\text { concen- } \\
\text { tration } \\
\text { (ng/L) }\end{array}$} & \multirow[b]{2}{*}{$\begin{array}{l}\text { Measured } \\
\text { reacration } \\
\text { coefficient } \\
\text { (base e } \\
\text { unit/d) }\end{array}$} & \multirow[b]{2}{*}{$\begin{array}{c}\text { Measure- } \\
\text { ment } \\
\text { error }\end{array}$} & \multicolumn{4}{|c|}{ Travel time to } \\
\hline & & & & & & $\begin{array}{l}\text { Leading } \\
\text { edge } \\
\text { (h) }\end{array}$ & $\begin{array}{l}\text { Peak } \\
\text { (h) }\end{array}$ & $\begin{array}{l}\text { Centroid } \\
\text { (h) }\end{array}$ & $\begin{array}{c}\text { Trailing } \\
\text { edge } \\
\text { (h) }\end{array}$ \\
\hline
\end{tabular}

Beaver Brook near Litteton, Mass.
A $\quad 6-17-86$
L
$46 \quad 1.62$
0.14
10.7
15.7
37.8
123.7

Assabet River near Westborough, Mass.

$\begin{array}{lllrrrrrrr}\text { A } & 5-13-86 & \text { L } & 3 & 1.46 & .15 & 2.4 & 2.9 & 3.4 & 5.6 \\ \text { A } & 8-05-86 & \text { L } & 7 & 5.78 & 1.17 & 5.7 & 6.8 & 8.2 & 17.1 \\ \text { A } & 10-28-86 & \text { L } & 24 & .79 & .26 & 3.5 & 4.6 & 12.5 & 45.6 \\ \text { B } & 8-05-86 & \text { L } & 8 & 2.35 & .33 & 3.3 & 4.8 & 5.4 & 6.8\end{array}$

Sudbury River near Wayland, Mass.
A $\quad 11-16-87$
L
$\begin{array}{lll}48 & .19 & .18\end{array}$
8.6
10.1
13.4
24.3

Ipswich River near Topsfield, Mass.

$\begin{array}{rrrrrrrrrr}\text { A } & 6-23-87 & \text { L } & 39 & 1.50 & 1.14 & 20.3 & 24.2 & 26.0 & 43.0 \\ \text { B } & 6-23-87 & \text { I } & 39 & .38 & .39 & 18.0 & 22.6 & 38.8 & 162.0\end{array}$

Taunton River near Bridgewater, Mass.

$\begin{array}{rrrrrrrrrr}\text { A } & 5-03-88 & \mathrm{~L} & 19 & .23 & .05 & 5.3 & 5.5 & 5.8 & 6.9 \\ \mathrm{~A} & 8-23-88 & \mathrm{~L} & 11 & .16 & .11 & 21.8 & 23.0 & 23.2 & 25.1\end{array}$


Appendix 2.--Reach characteristics, time-of-travel characteristics, and measured reaeration coefficients from 42 tracer studies--Continued

\begin{tabular}{|c|c|c|c|c|c|c|c|c|c|}
\hline \multirow[b]{2}{*}{ Reach } & \multirow[b]{2}{*}{$\begin{array}{l}\text { Study } \\
\text { date }\end{array}$} & \multirow[b]{2}{*}{$\begin{array}{l}\text { Reach } \\
\text { descrip- } \\
\text { tor }^{1}\end{array}$} & \multirow[b]{2}{*}{$\begin{array}{l}\text { Suspended- } \\
\text { solids } \\
\text { concen- } \\
\text { tration } \\
(\mathrm{mg} / \mathrm{L})\end{array}$} & \multirow[b]{2}{*}{$\begin{array}{c}\text { Measured } \\
\text { reacration } \\
\text { coefficient } \\
\text { (basc e } \\
\text { unit/d) }\end{array}$} & \multirow[b]{2}{*}{$\begin{array}{c}\text { Measure- } \\
\text { ment } \\
\text { error }\end{array}$} & \multicolumn{4}{|c|}{ Travel time to } \\
\hline & & & & & & $\begin{array}{l}\text { Leading } \\
\text { edge } \\
\text { (h) }\end{array}$ & $\begin{array}{l}\text { Peak } \\
\text { (h) }\end{array}$ & $\begin{array}{l}\text { Centroid } \\
\text { (h) }\end{array}$ & $\begin{array}{l}\text { Trailing } \\
\text { edge } \\
\text { (h) }\end{array}$ \\
\hline
\end{tabular}

\begin{tabular}{rrrrrr|rrrr} 
A & $6-21-88$ & L & 25 & 3.67 & .86 & 5.3 & 7.4 & 8.0 & 13.0 \\
A & $9-23-88$ & L & 13 & 1.43 & 1.19 & 16.6 & 24.0 & 25.9 & 40.6 \\
B & $9-23-88$ & L & 15 & 1.08 & 2.25 & 35.8 & 57.0 & 100.0 & 101.7 \\
C & $10-21-87$ & I & 0 & .66 & .35 & 9.7 & 12.5 & 13.7 & 20.1 \\
C & $6-21-88$ & I & 24 & 2.63 & .22 & 28.8 & 30.8 & 33.6 & 41.6
\end{tabular}

Outer River near Gardner, Mass.

\begin{tabular}{llllll|llll} 
A & $5-19-87$ & $\mathrm{H}$ & 19 & .78 & .25 & 6.4 & 8.3 & 9.1 & 21.9
\end{tabular}

Mill River near Amherst, Mass.

\begin{tabular}{lrlrrr|rrrr} 
A & $8-03-87$ & L & 350 & 6.85 & .69 & 2.5 & 3.0 & 3.5 & 5.5 \\
B & $8-03-87$ & L & 350 & 10.99 & 1.00 & 2.1 & 2.5 & 3.4 & 6.0
\end{tabular}

Natty Pond Brook near Hubbardston, Mass.

$\begin{array}{rrrrrrrrrr}\text { A } & 6-25-86 & \text { L } & 14 & .91 & .51 & 8.5 & 14.1 & 17.3 & 41.9 \\ \text { B } & 9-17-85 & \text { H } & 17 & 8.22 & .36 & 8.7 & 11.1 & 14.1 & 33.9 \\ \text { C } & 5-22-85 & \text { L } & 8 & 2.74 & .39 & 3.1 & 3.9 & 4.4 & 7.6 \\ \text { C } & 8-20-85 & \text { L } & 6 & 1.94 & .78 & 5.0 & 13.1 & 13.4 & 26.2 \\ \text { D } & 5-22-85 & \text { L } & 8 & 2.05 & .46 & 5.0 & 6.2 & 6.9 & 13.2\end{array}$


Appendix 2.--Reach characteristics, time-of-travel characteristics, and measured reaeration coefficients from 42 tracer studies--Continued

\begin{tabular}{|c|c|c|c|c|c|c|c|c|c|}
\hline \multirow[b]{2}{*}{ Reach } & \multirow[b]{2}{*}{$\begin{array}{l}\text { Study } \\
\text { date }\end{array}$} & \multirow[b]{2}{*}{$\begin{array}{c}\text { Reach } \\
\text { descrip- } \\
\text { tor }^{1}\end{array}$} & \multirow[b]{2}{*}{$\begin{array}{l}\text { Suspended- } \\
\text { solids } \\
\text { concen- } \\
\text { tration } \\
(\mathrm{mg} / \mathrm{L})\end{array}$} & \multirow[b]{2}{*}{$\begin{array}{l}\text { Measured } \\
\text { reaeration } \\
\text { coefficient } \\
\text { (base e } \\
\text { unil/d) }\end{array}$} & \multirow[b]{2}{*}{$\begin{array}{c}\text { Measure- } \\
\text { ment } \\
\text { error }\end{array}$} & \multicolumn{4}{|c|}{ Travel time to } \\
\hline & & & & & & $\begin{array}{c}\text { Leading } \\
\text { edge } \\
\text { (h) }\end{array}$ & $\begin{array}{c}\text { Peak } \\
\text { (h) }\end{array}$ & $\begin{array}{l}\text { Centroid } \\
\text { (h) }\end{array}$ & $\begin{array}{c}\text { Trailing } \\
\text { edge } \\
\text { (h) }\end{array}$ \\
\hline
\end{tabular}

Ware River near Barre, Mass.
A $\quad 6-28-88$
L
$17 \quad 1.31$
1.72
23.2
29.9
48.7
92.0

Karner Brook at South Egremont, Mass.

$\begin{array}{rrrrrrrrrr}\text { A } & 10-14-88 & \text { L } & 9 & 2.40 & .32 & 1.9 & 2.8 & 3.5 & 6.8 \\ \text { B } & 10-14-88 & \text { I } & 9 & 1.02 & .28 & 36.0 & 63.5 & 67.3 & 234.4\end{array}$

Batten Kill near Greenwich, N.Y.
A $\quad 8-24-87$
1
$18 \quad 1.34$
.28
4.4
5.5
6.8
9.1

$\underline{\text { Hoosic River near Adams, Mass. }}$

$\begin{array}{lllrrrrrrr}\text { A } & 6-09-87 & \text { H } & 48 & 6.74 & .73 & 2.9 & 3.4 & 3.6 & 4.7 \\ \text { A } & 6-02-88 & \text { H } & 6 & 5.60 & .45 & 1.9 & 2.2 & 2.3 & 2.9 \\ \text { A } & 8-17-88 & \text { H } & 35 & 10.16 & 1.25 & 3.3 & 4.1 & 4.3 & 5.5 \\ \text { B } & 6-09-87 & \text { I } & 48 & 7.33 & .72 & 2.7 & 3.2 & 3.7 & 4.9 \\ \text { B } & 8-17-88 & \text { I } & 0 & 9.20 & 1.05 & 3.1 & 3.8 & 4.1 & 4.9\end{array}$

Normans Kill near Westmere, N.Y.
A $\quad 6-08-88$
$\begin{array}{lll}\text { L } & 8 & 1.92\end{array}$
.11
5.7
7.4
9.4
16.9

Coeymans Creck near Coeymans, N.Y.
A $\quad 9-29-87$
L.
$6 \quad 4.96$
.06
6.1
9.0
9.3
12.2 
Appendix 2.--Reach characteristics, time-of-travel characteristics, and measured reaeration coefficients from 42 tracer studies--Continued

\begin{tabular}{|c|c|c|c|c|c|c|c|c|c|}
\hline \multirow[b]{2}{*}{ Reach } & \multirow[b]{2}{*}{$\begin{array}{l}\text { Study } \\
\text { date }\end{array}$} & \multirow[b]{2}{*}{$\begin{array}{l}\text { Reach } \\
\text { descrip- } \\
\text { tor }^{3}\end{array}$} & \multirow[b]{2}{*}{$\begin{array}{l}\text { Suspended- } \\
\text { solids } \\
\text { concen- } \\
\text { tration } \\
(\mathrm{mg} / \mathrm{L})\end{array}$} & \multirow[b]{2}{*}{$\begin{array}{c}\text { Measured } \\
\text { reaeration } \\
\text { coefficient } \\
\text { (base e } \\
\text { unit/d) }\end{array}$} & \multirow[b]{2}{*}{$\begin{array}{c}\text { Measure- } \\
\text { ment } \\
\text { error }\end{array}$} & \multicolumn{4}{|c|}{ Travel time to } \\
\hline & & & & & & $\begin{array}{c}\text { Leading } \\
\text { edge } \\
\text { (h) }\end{array}$ & $\begin{array}{c}\text { Peak } \\
\text { (h) }\end{array}$ & $\begin{array}{l}\text { Centroid } \\
\text { (h) }\end{array}$ & $\begin{array}{l}\text { Trailing } \\
\text { edge } \\
\text { (h) }\end{array}$ \\
\hline
\end{tabular}

\section{Claverack Creek at Hudson, N.Y.}

$\begin{array}{llllllllll}\text { A } & 6-28-88 & \mathrm{I} & 10 & .21 & .16 & 32.3 & 48.4 & 55.2 & 85.5\end{array}$

West Branch Delaware River near Deposit, N.Y.
A $\quad 10-22-86$
L
$5 \quad 3.10$
.07
7.5
8.9
10.3
17.2

Susquehanna River at Phoenix Mills, N.Y.
A $\quad 8-09-88$
L
$13 \quad 2.66$
.08
3.5
7.1
7.8
11.2

Canisteo River at Homell, N.Y.
A $\quad 9-26-88$
$\begin{array}{lll}\text { L } & 29 & 2.13\end{array}$
.06
11.1
14.9
15.6
18.8

Caughdenoy Creek near Caughdenoy, N.Y.
A $\quad 6-13-88$
L
$11 \quad 1.33$
.06
15.2
21.6
$24.5 \quad 40.0$

South Sandy Creek near Ellisburg, N.Y.

\begin{tabular}{lllllll|l|l|l} 
A & $6-15-88$ & L & 3 & 5.89 & .07 & 3.2 & 4.3 & 4.5 & 8.7 \\
B & $6-15-88$ & L & 3 & 4.09 & .07 & 5.8 & 7.1 & 7.3 & 8.9
\end{tabular}

Indian River at Kelsey Bridge, N.Y.

\begin{tabular}{lllllllllll} 
A & $6-02-87$ & $\mathrm{~L}$ & 3 & .51 & .24 & 12.5 & 14.9 & 15.3 & 19.6 \\
\hline
\end{tabular}

${ }^{1} \mathrm{~L}$, low-slope stream; H, high-slope stream; I, impounded stream 


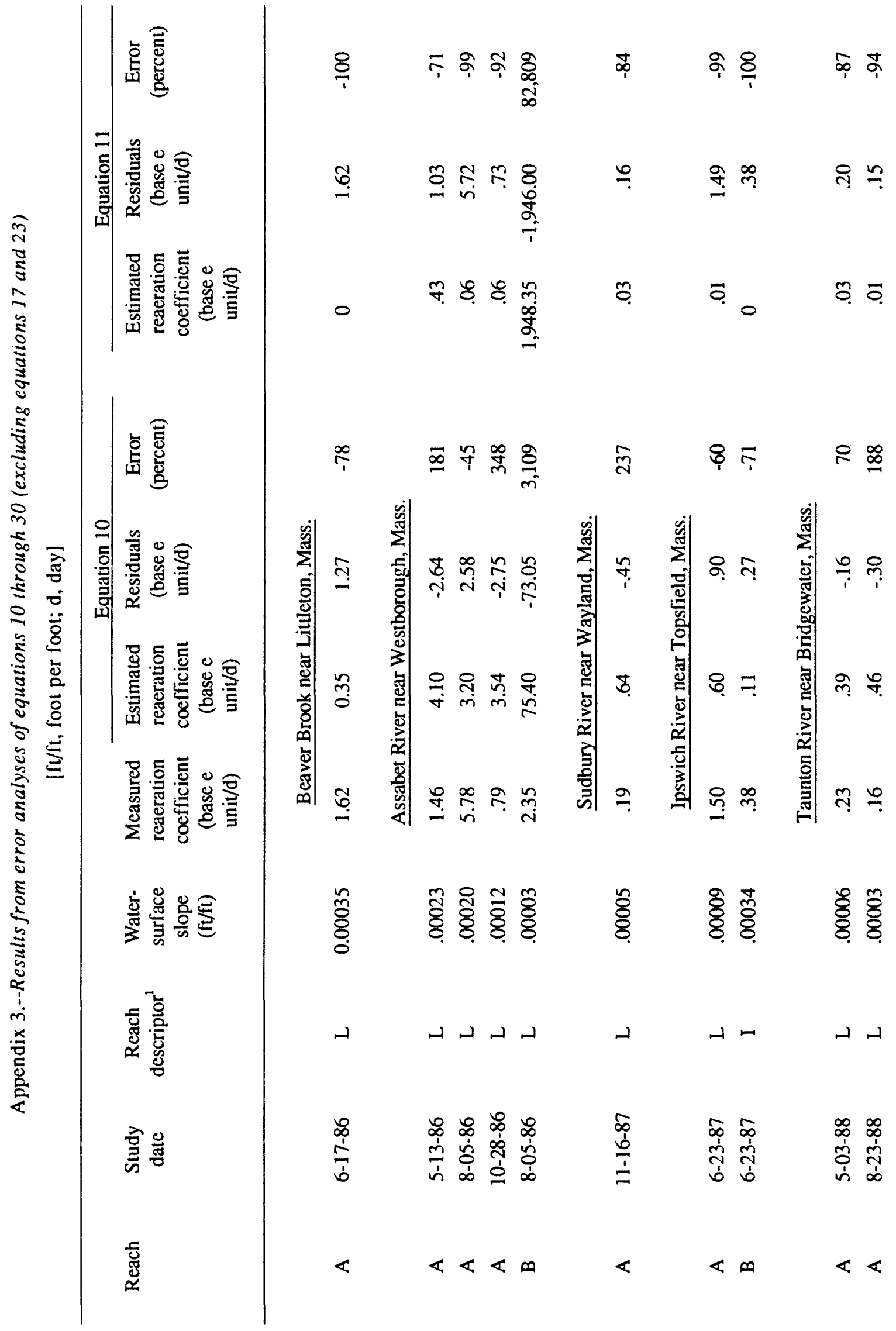

$$
\text { C. } 1
$$




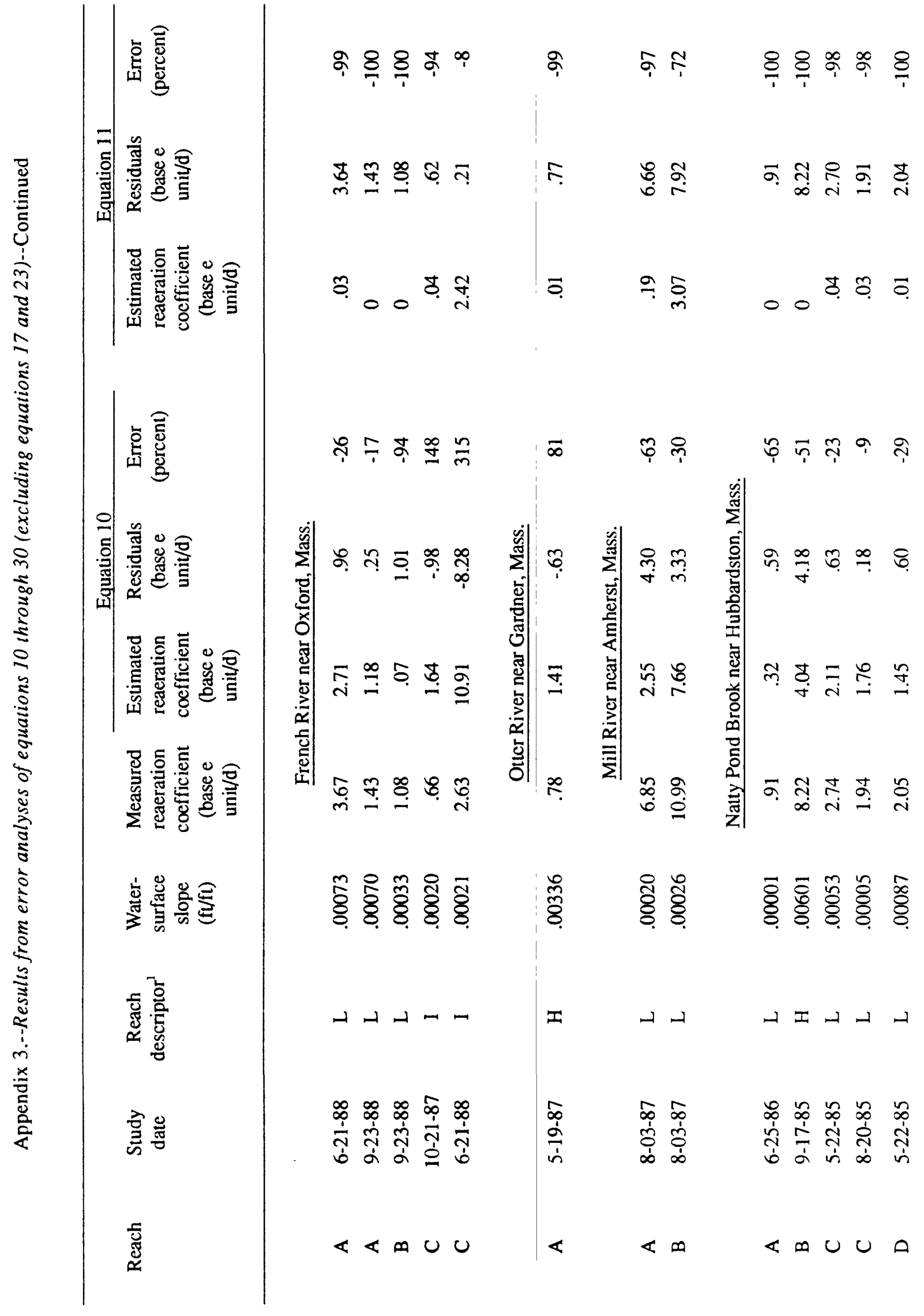




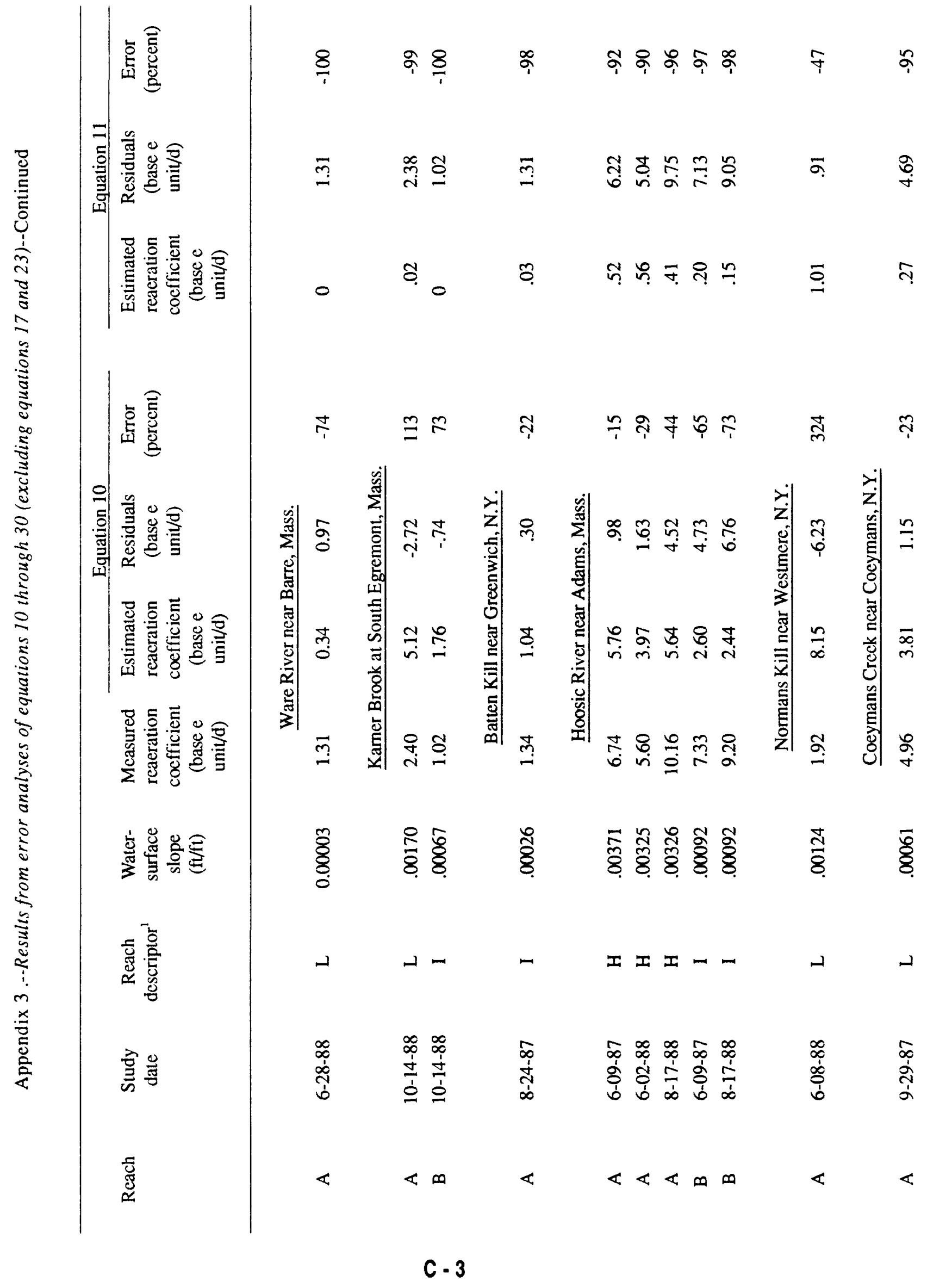




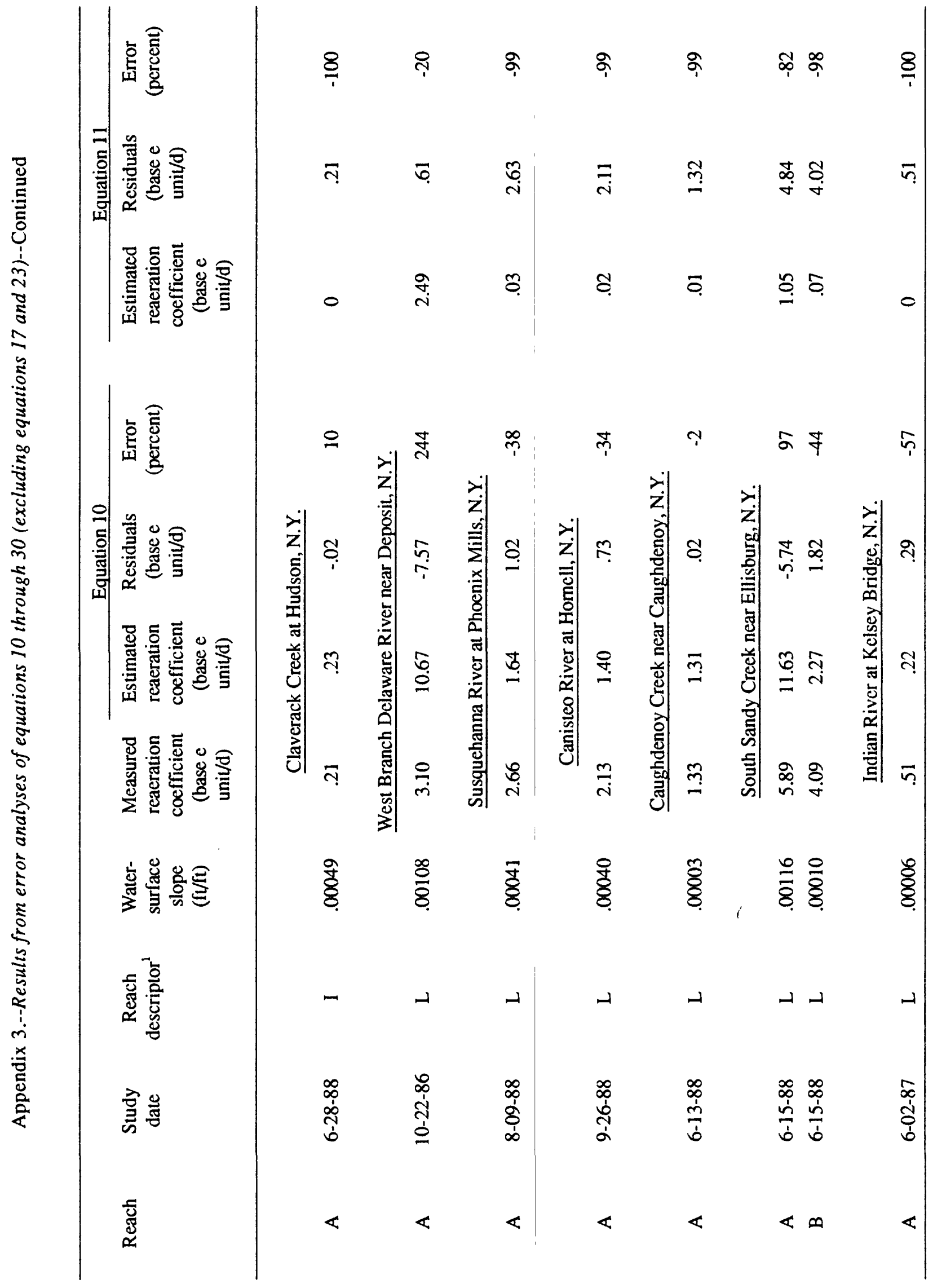




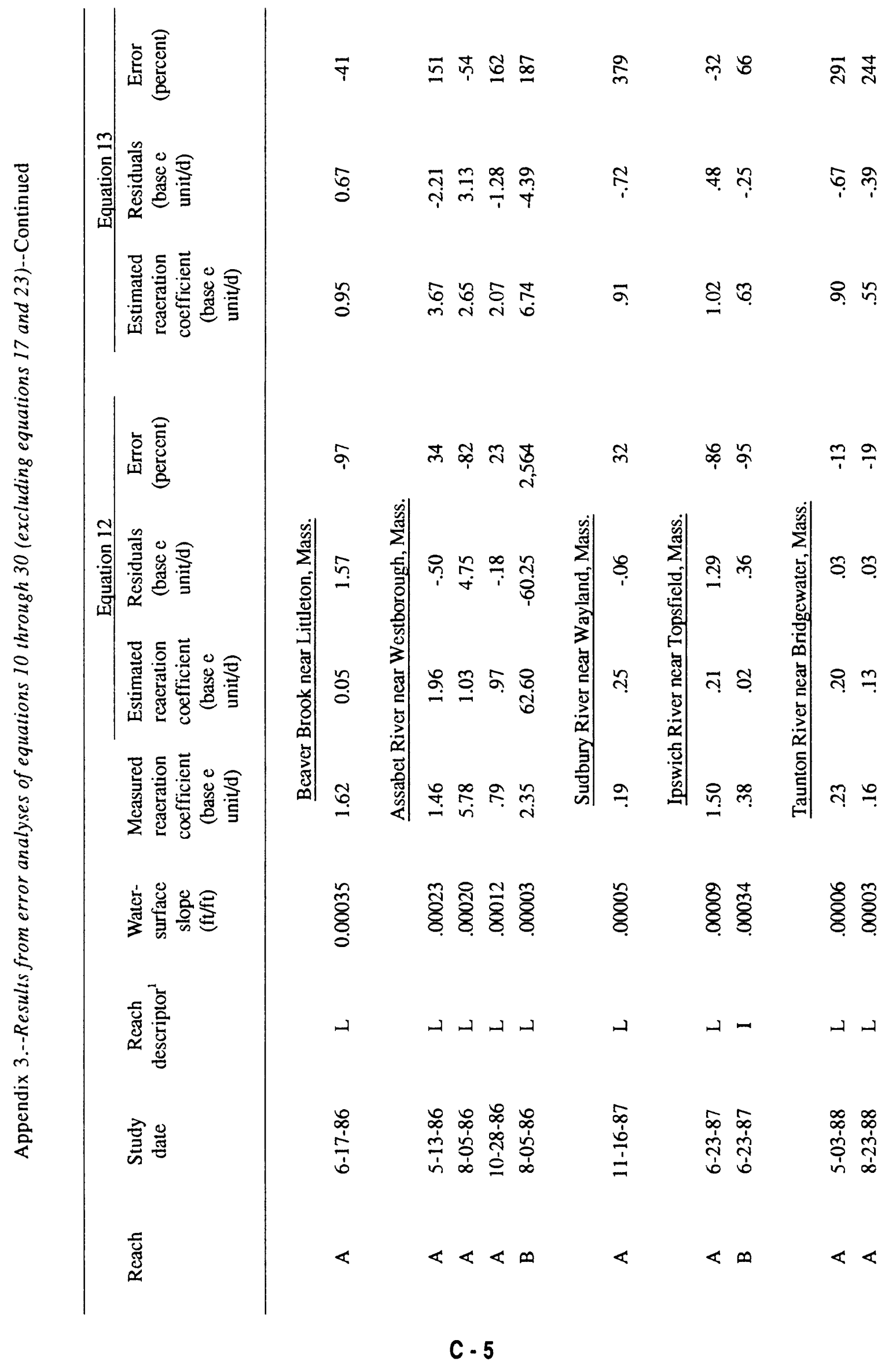




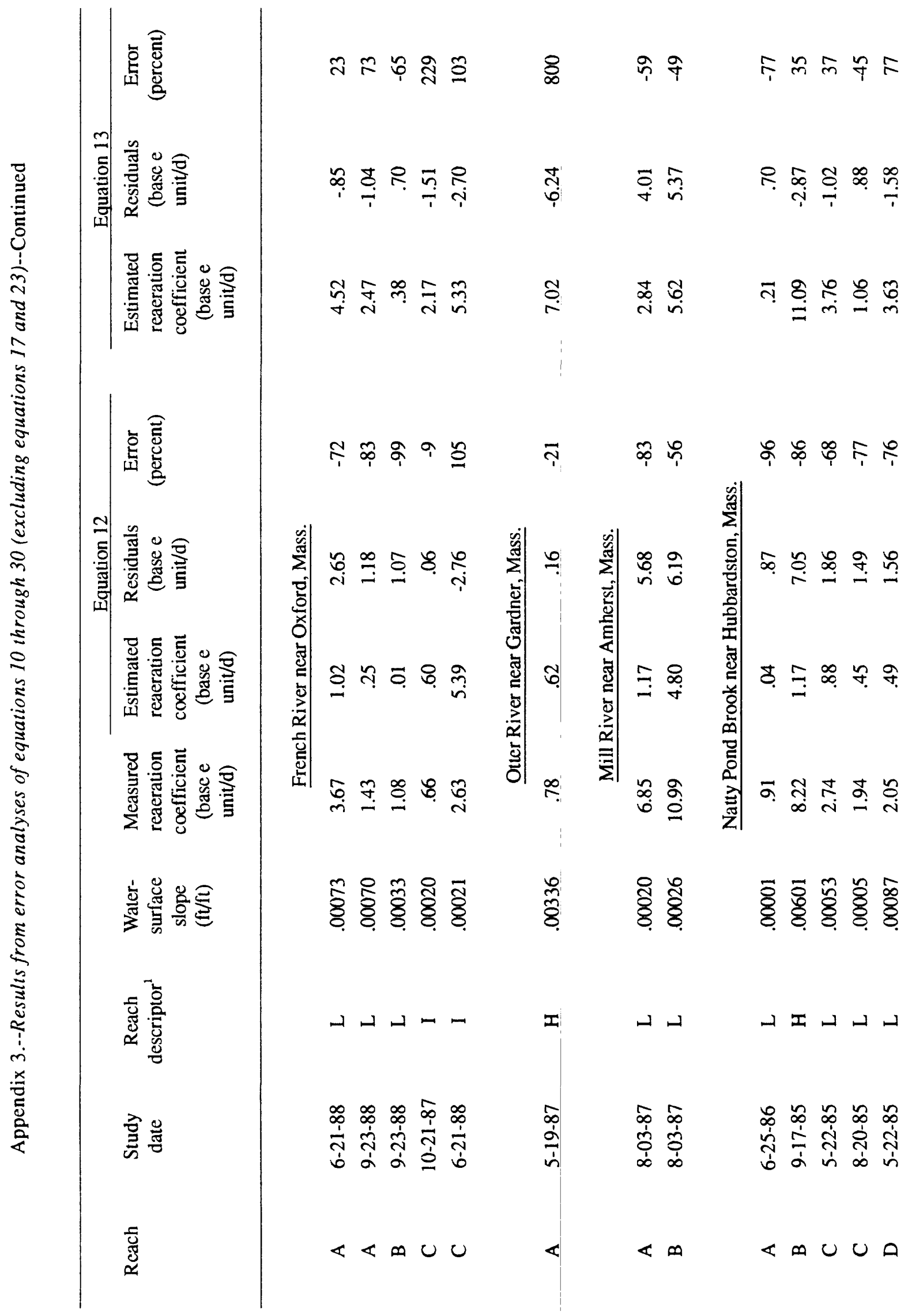




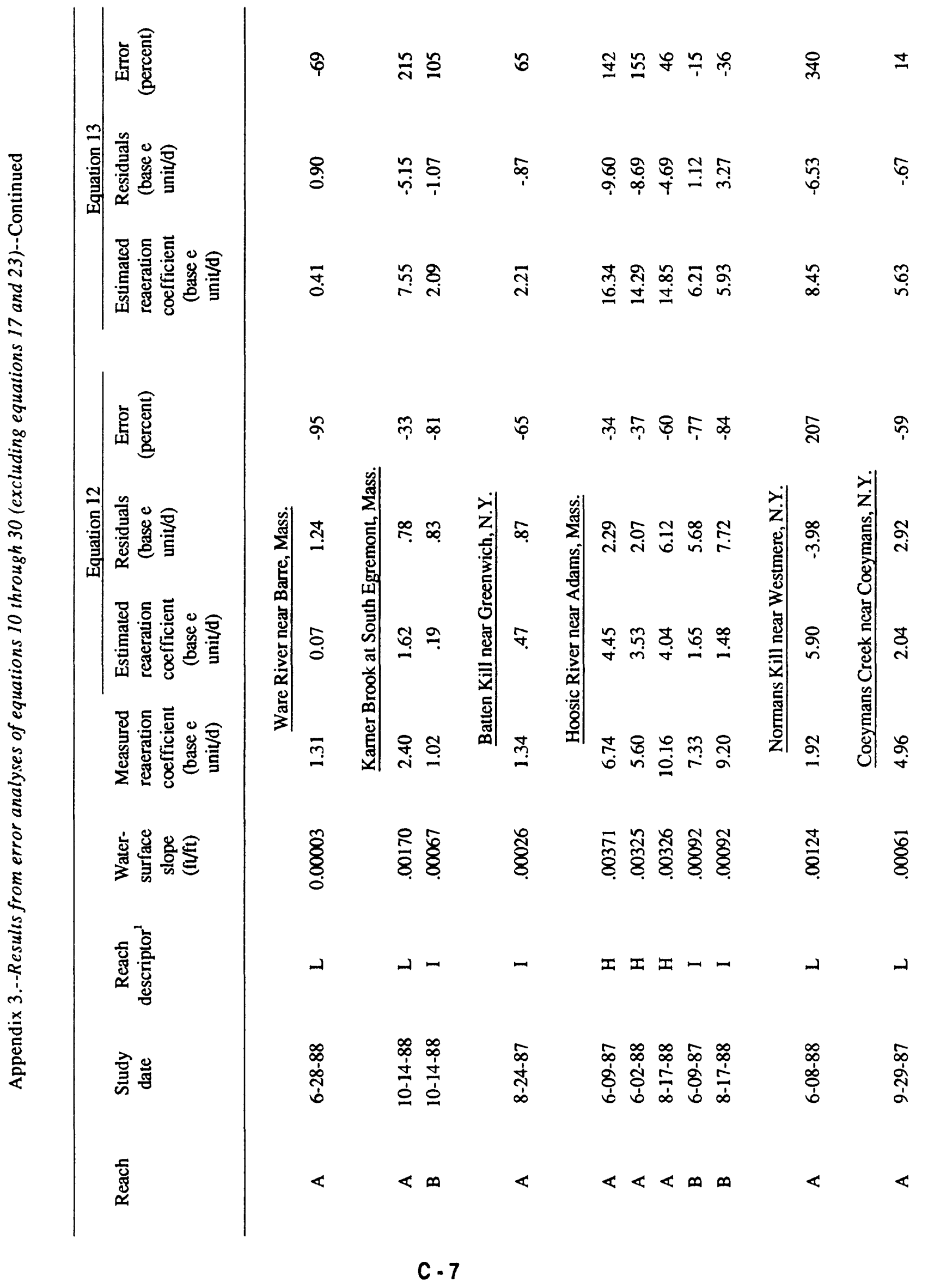




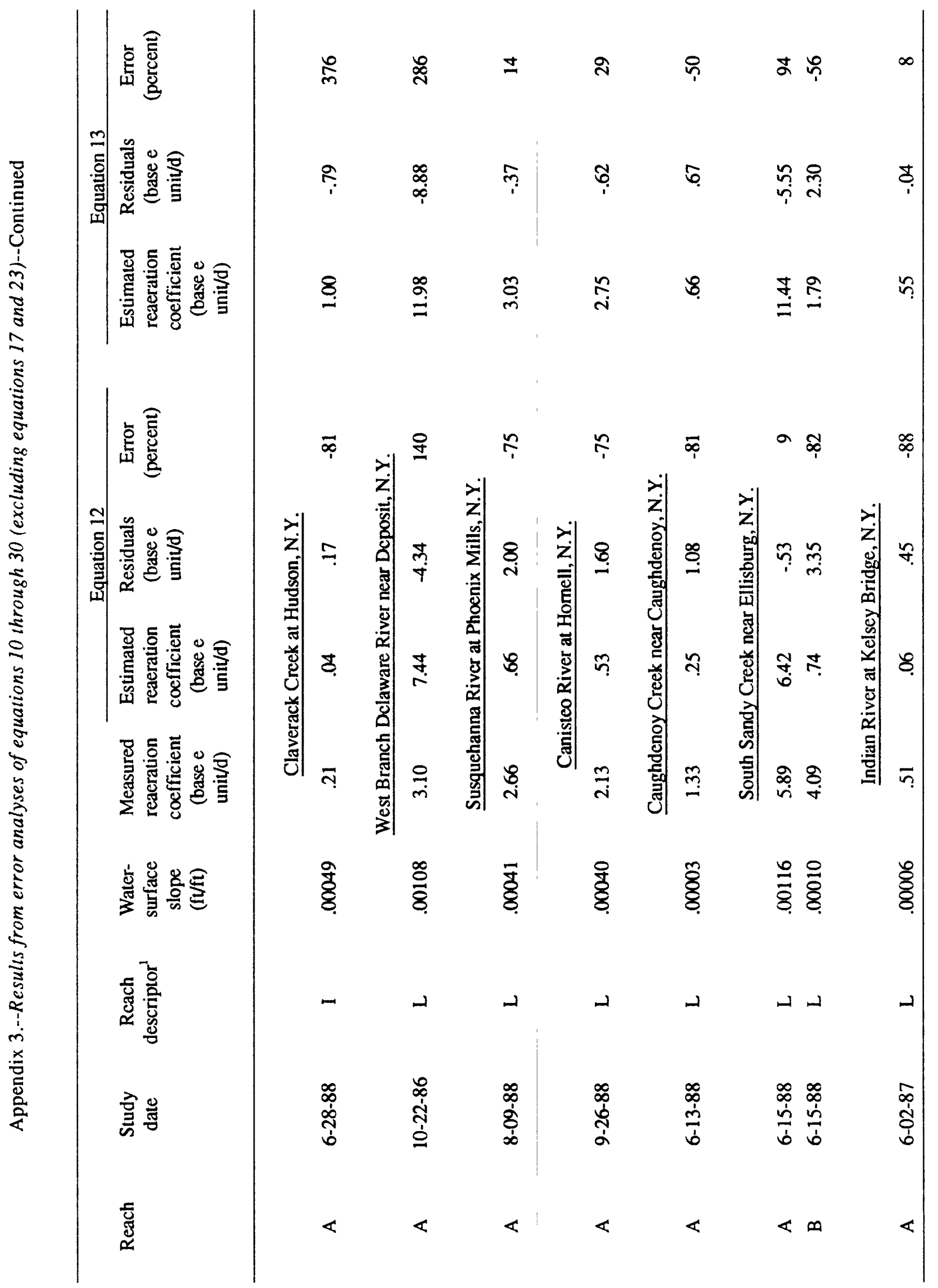




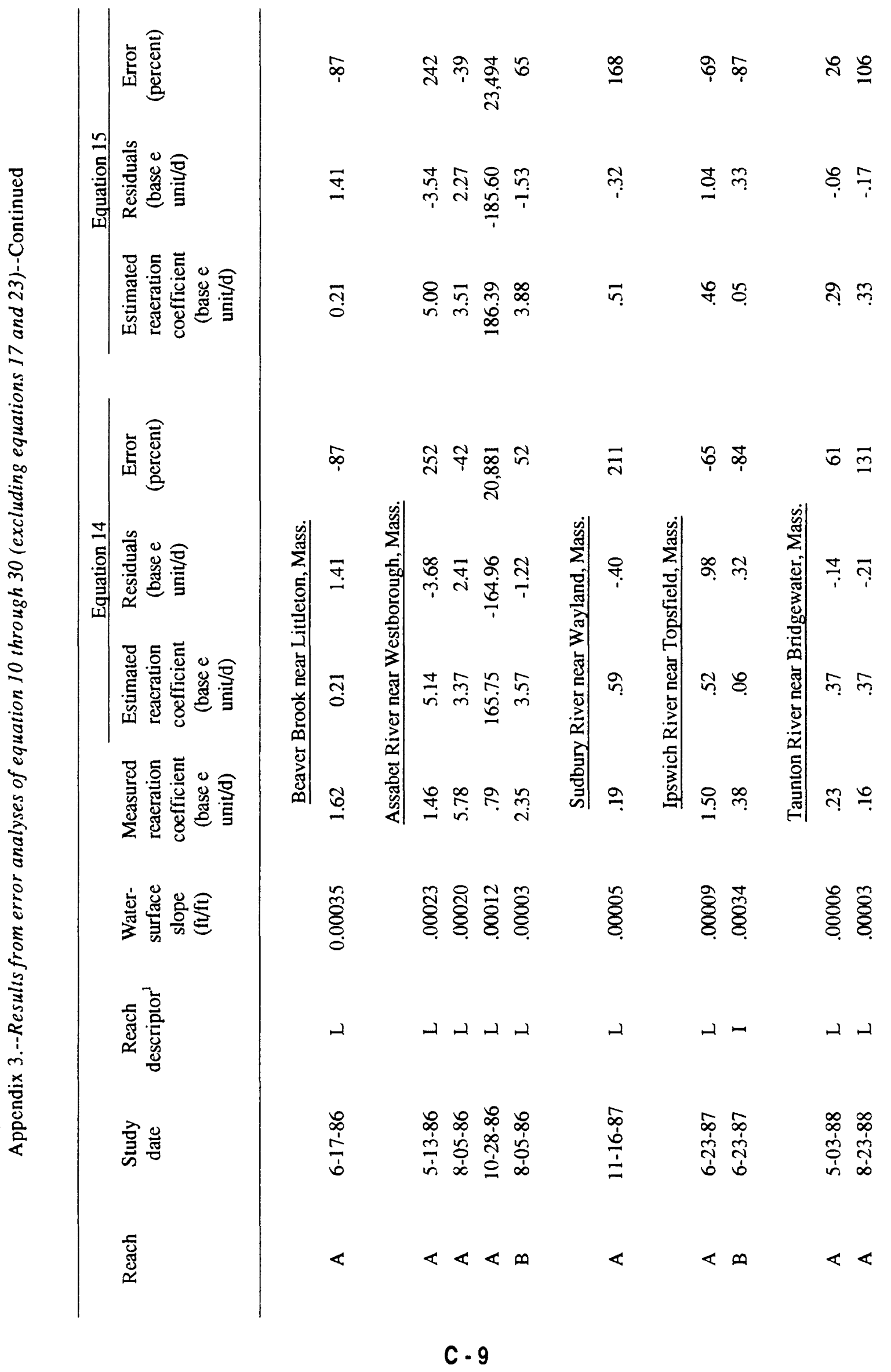




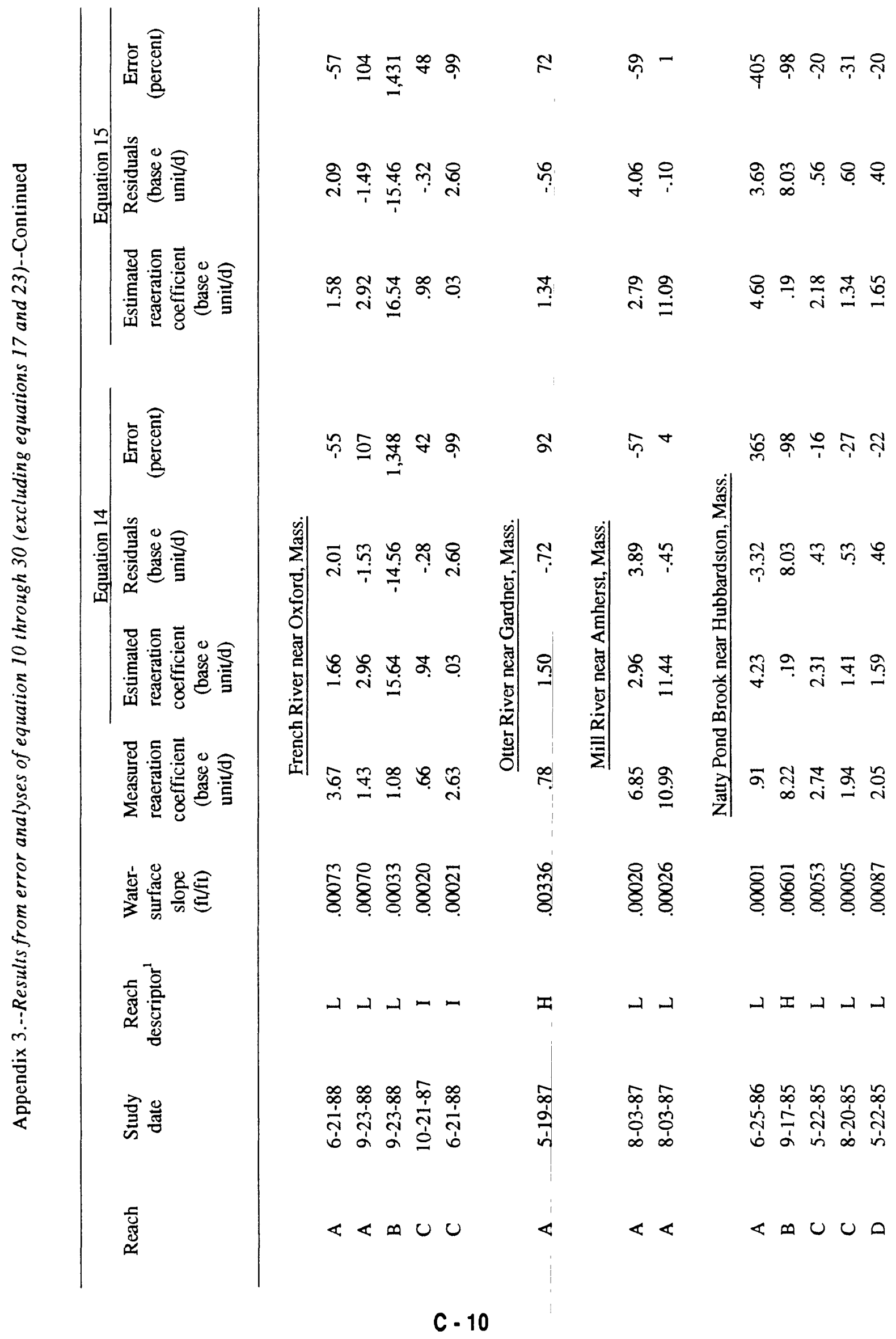




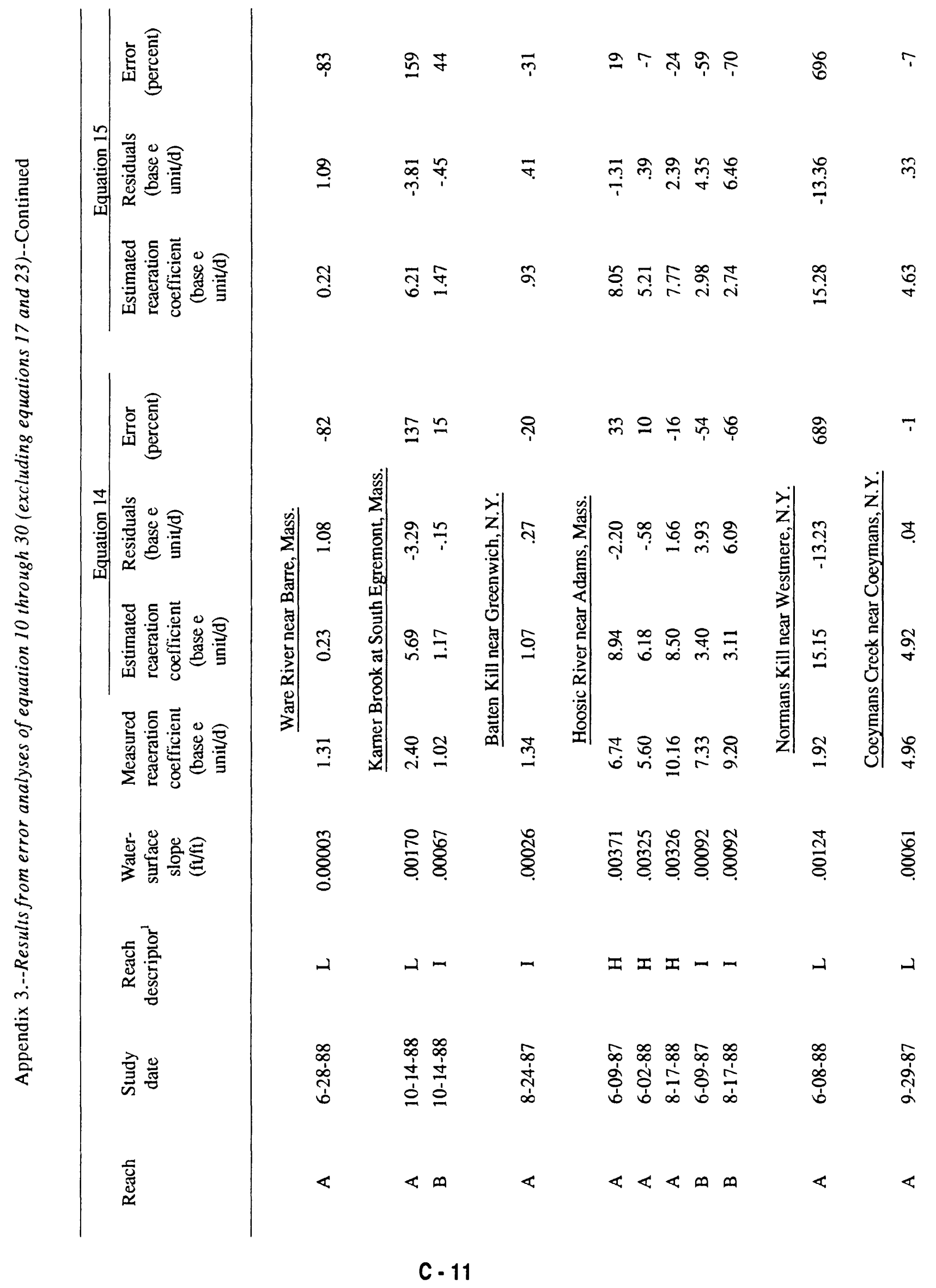




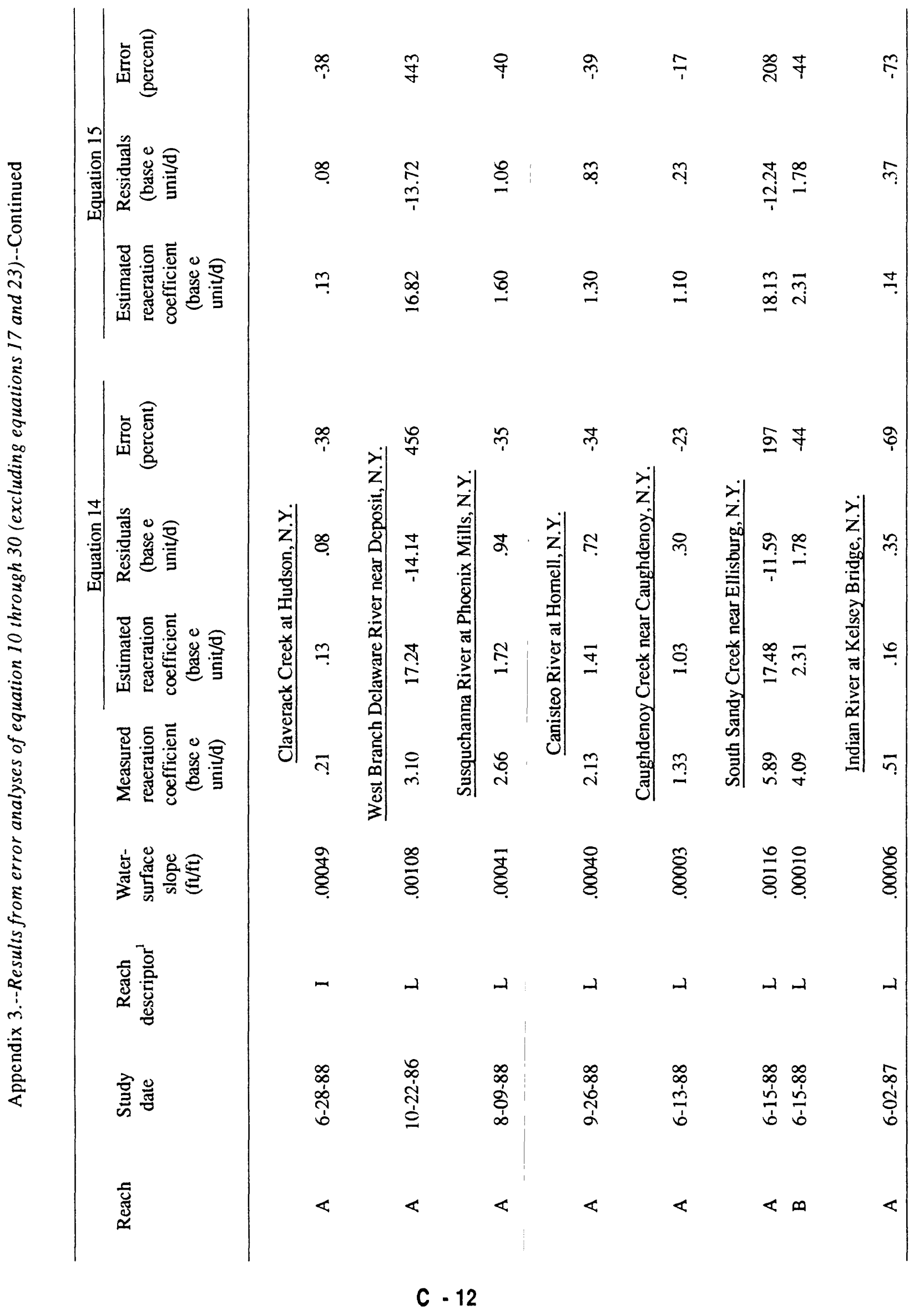




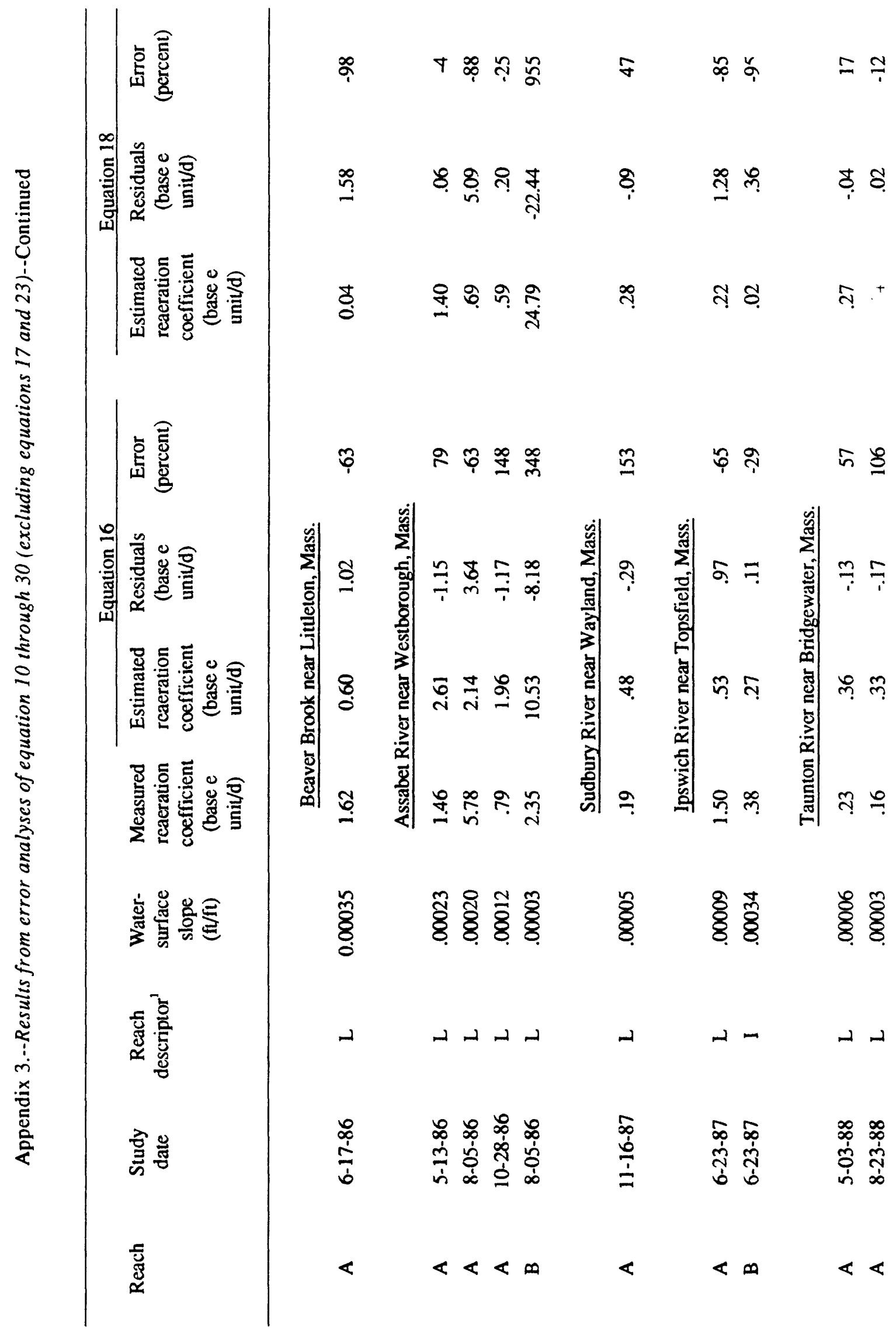




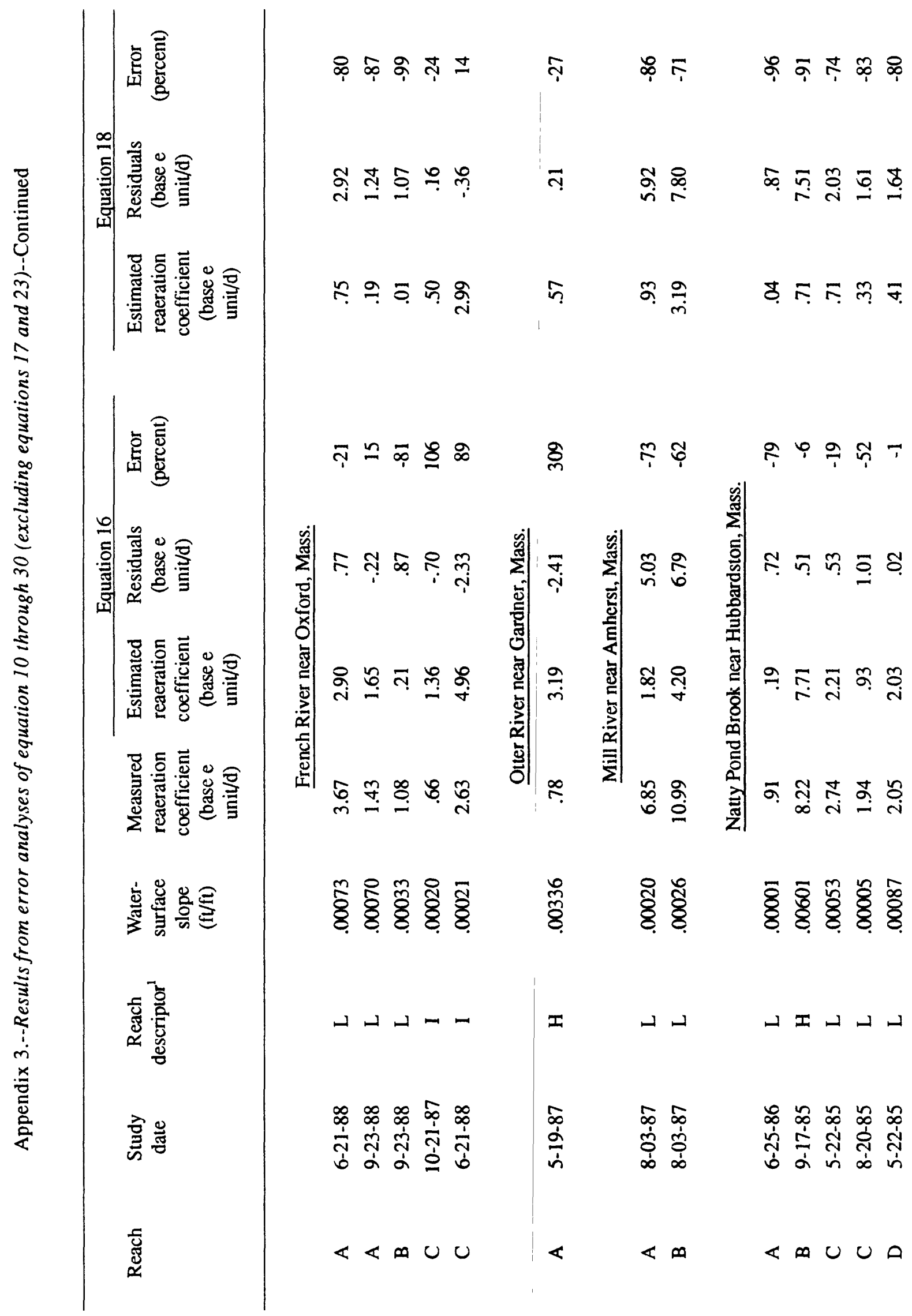




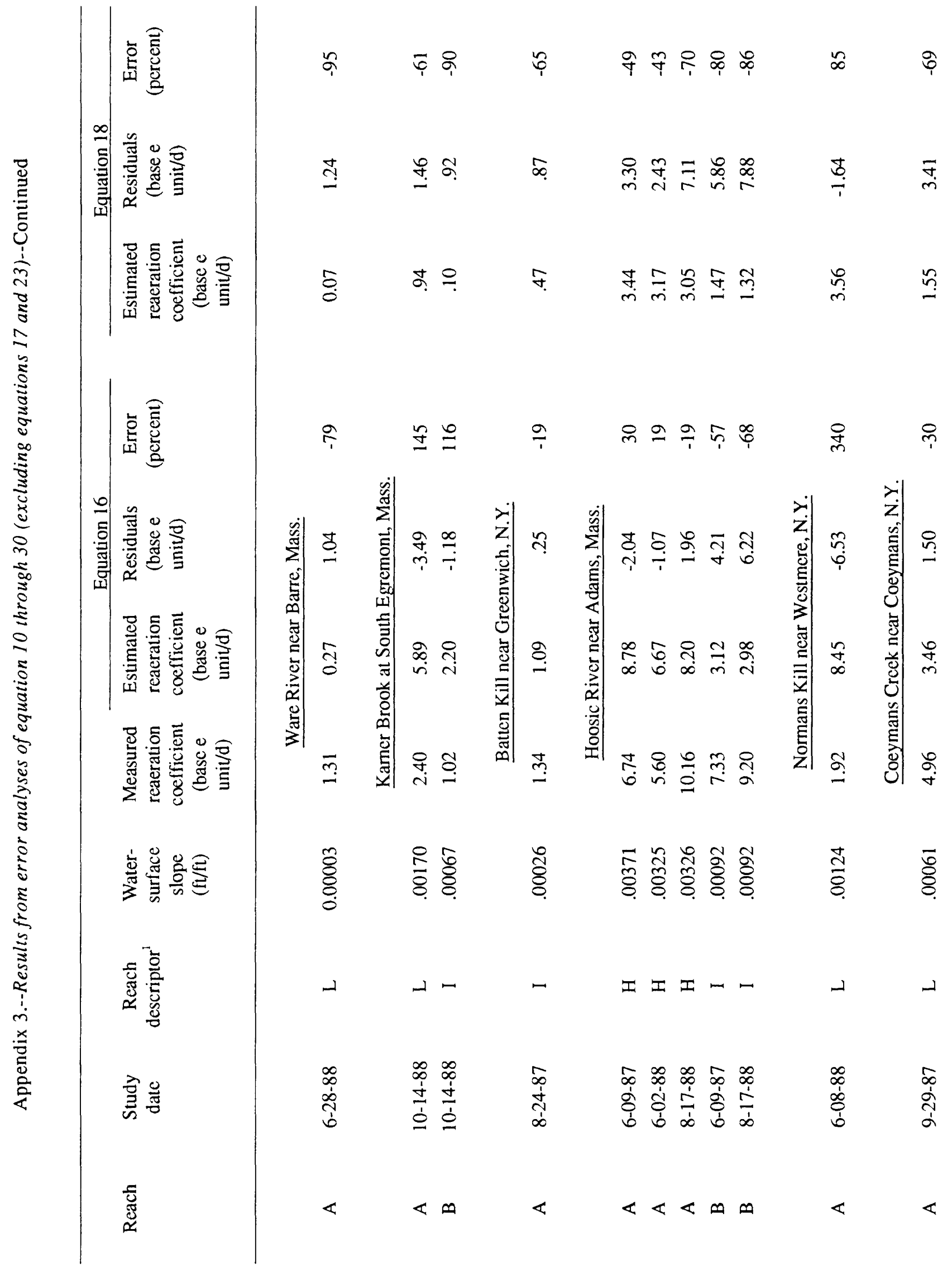




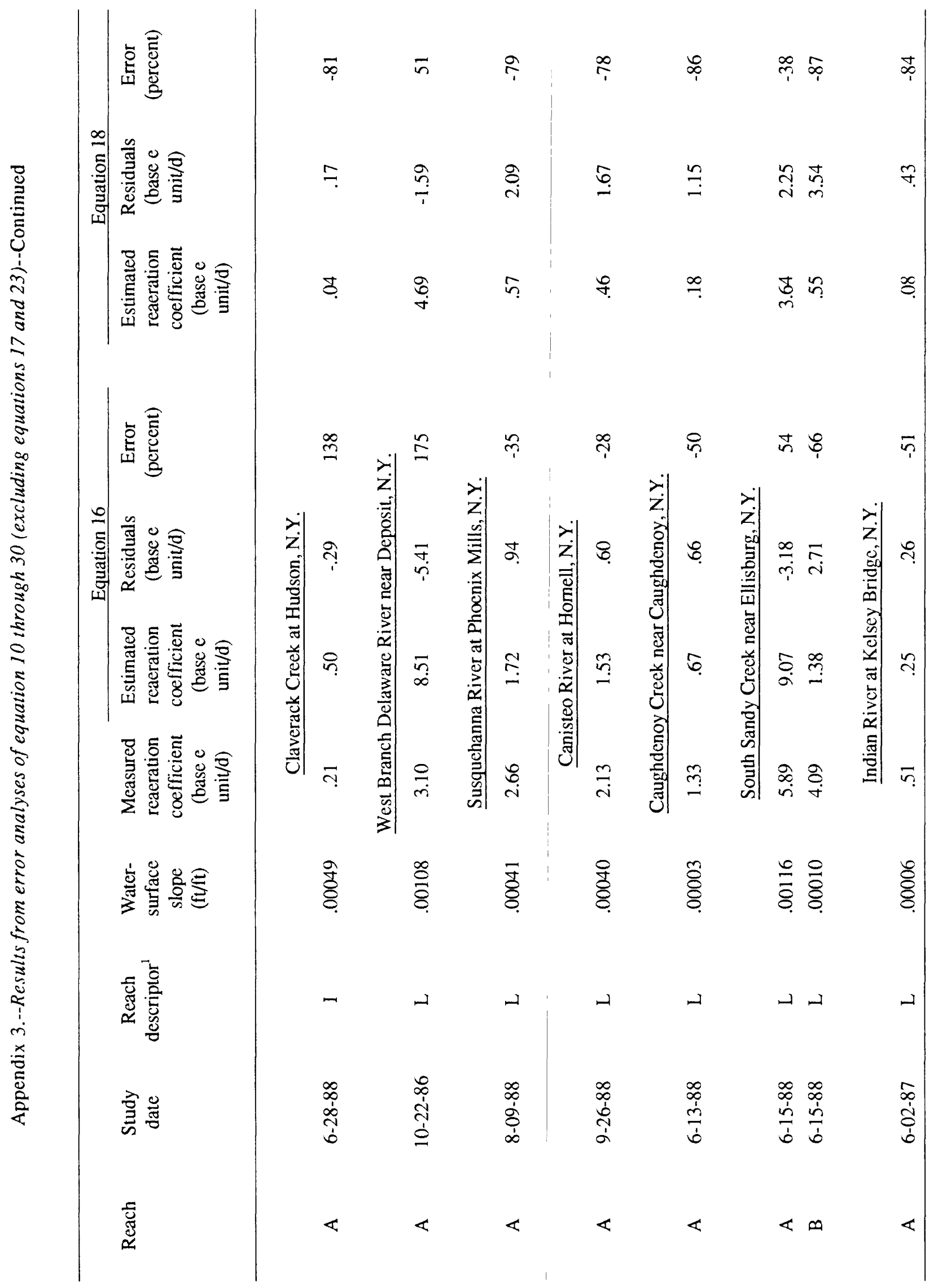




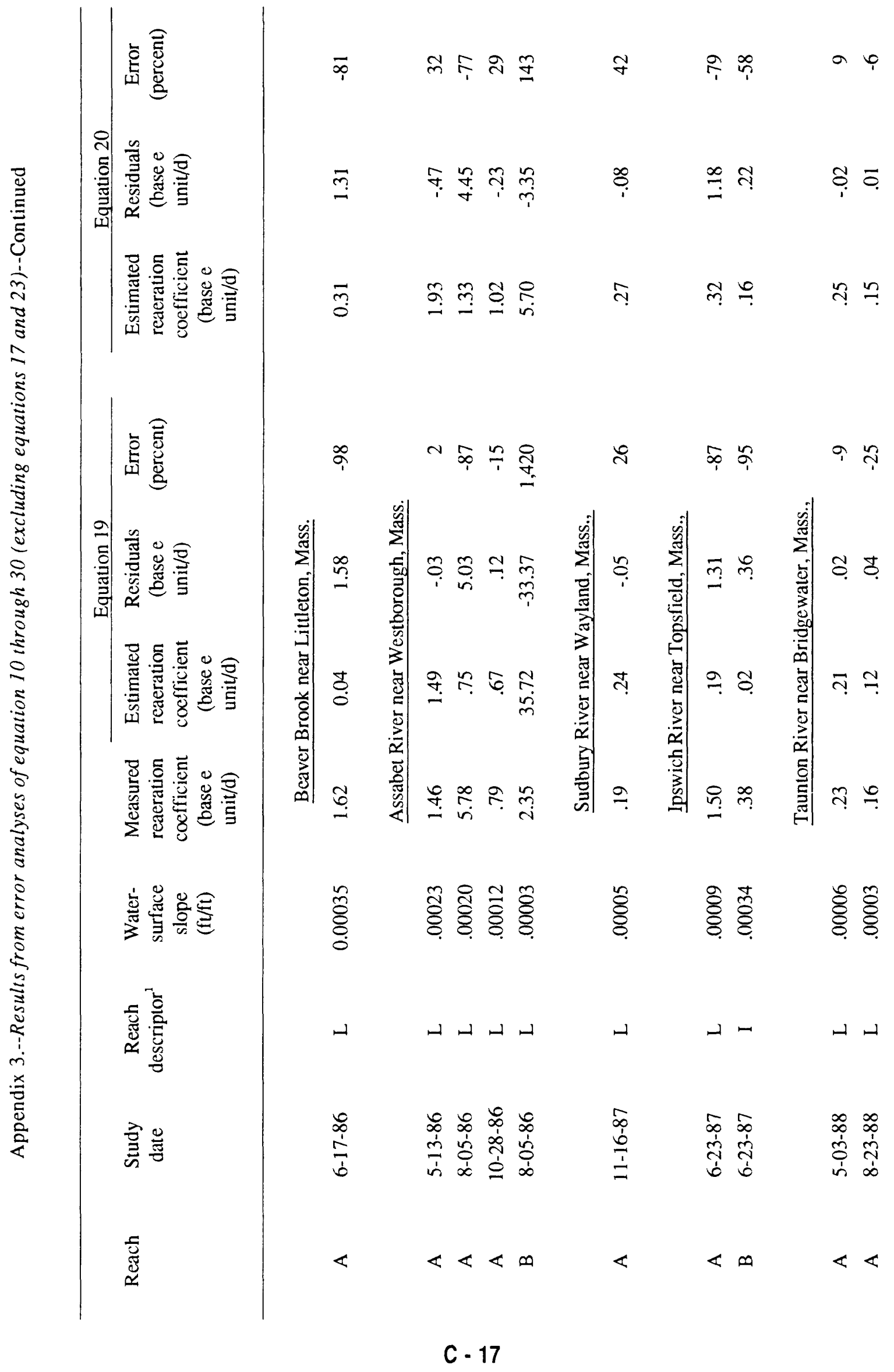




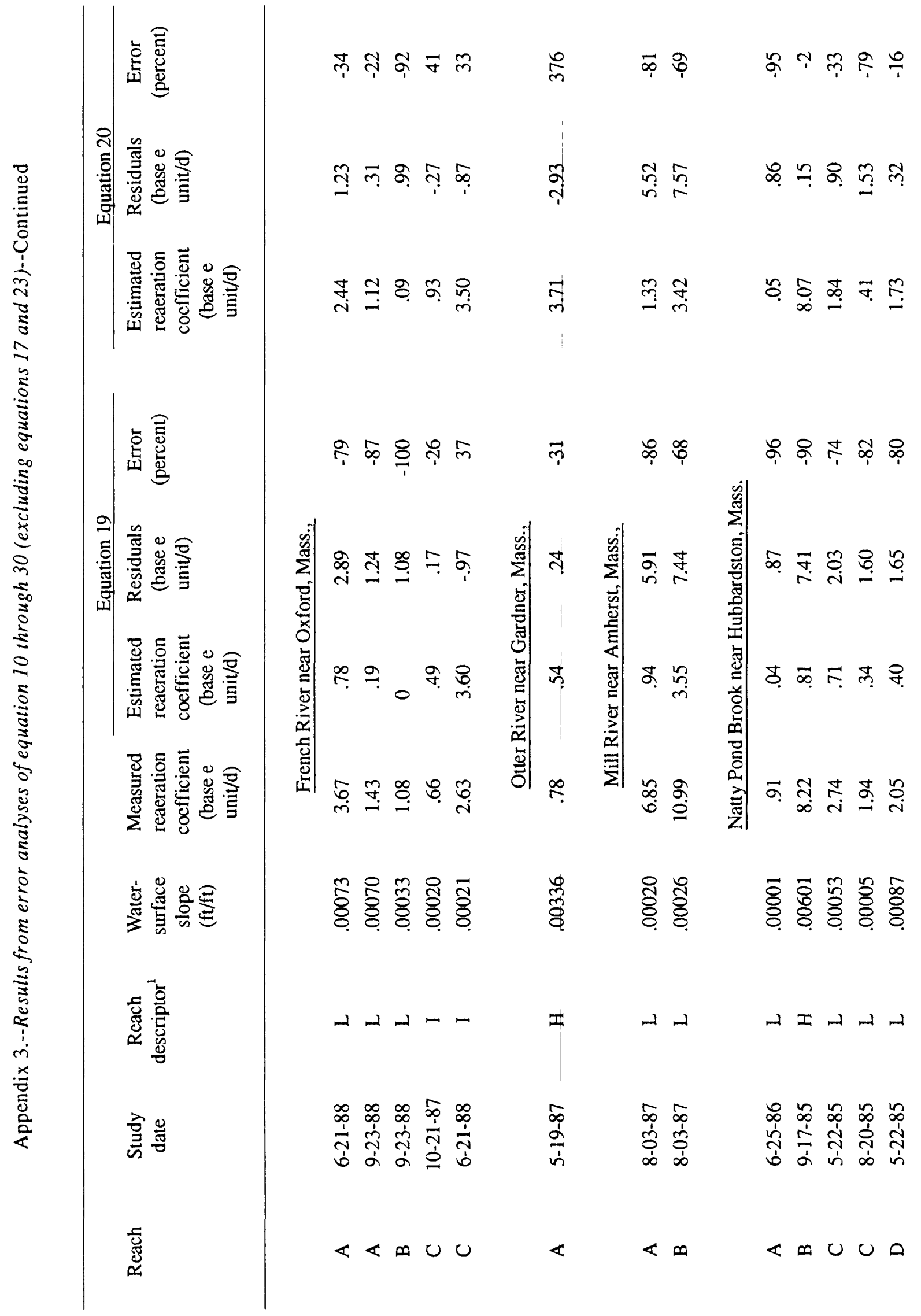




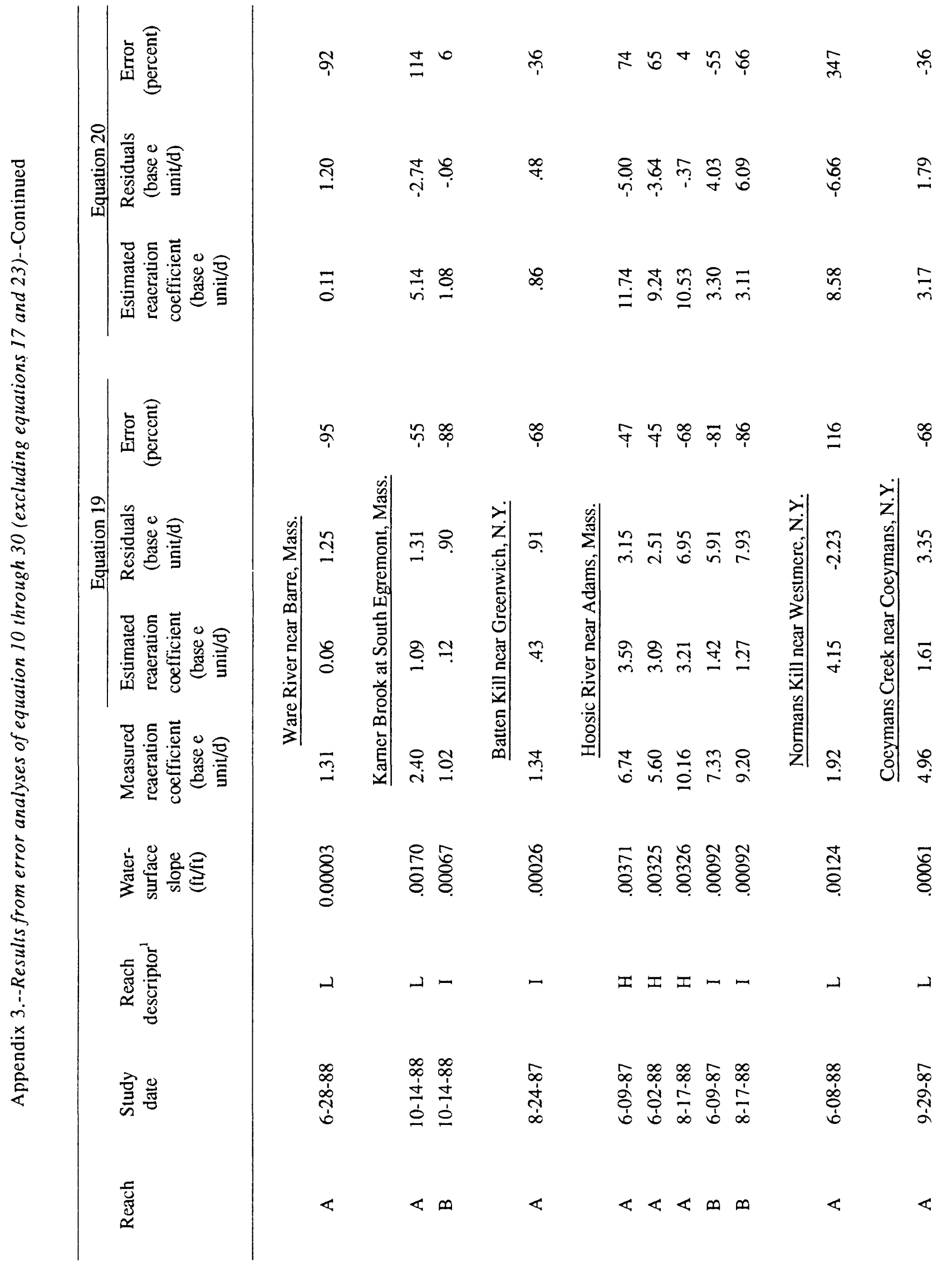




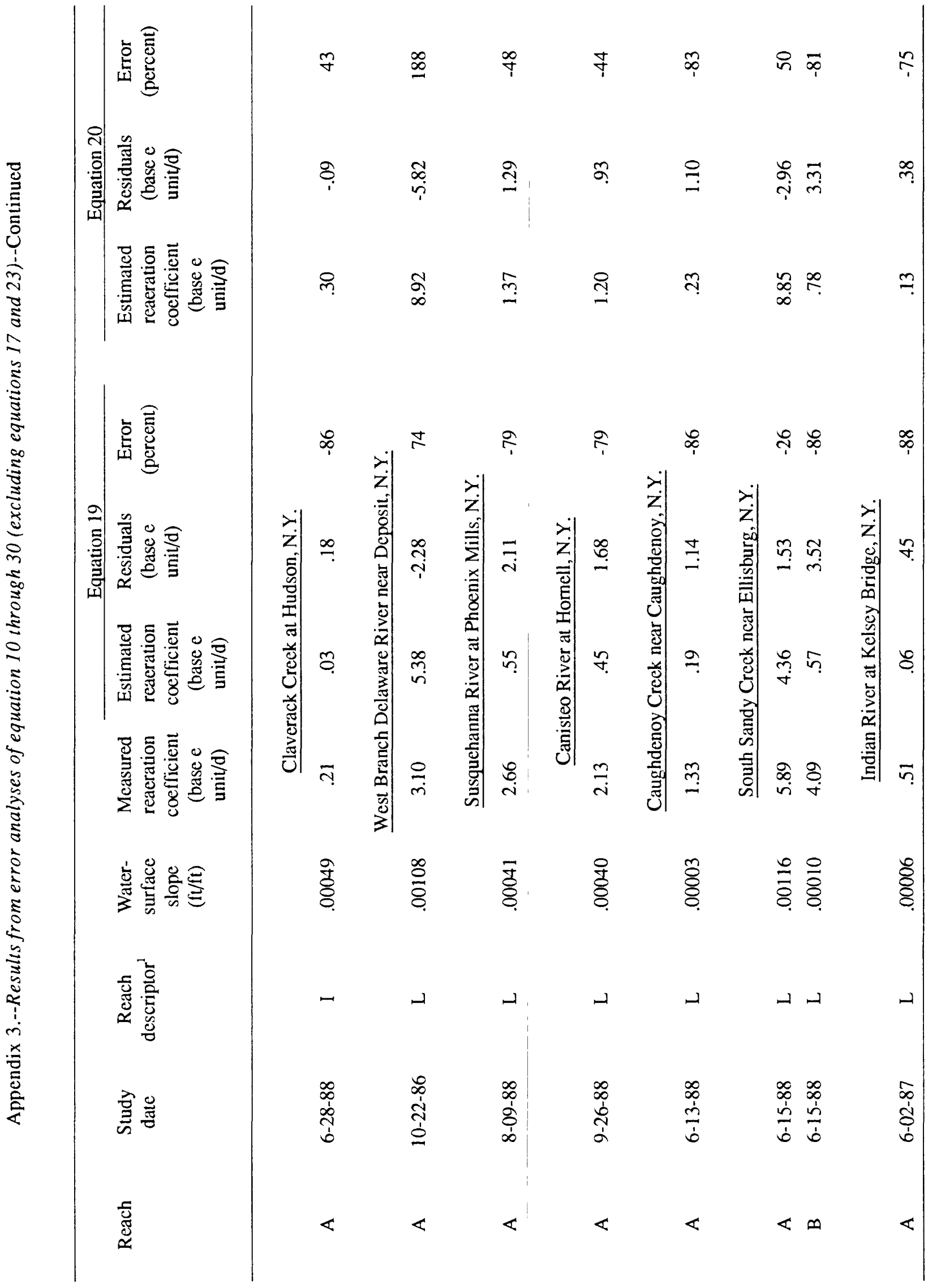




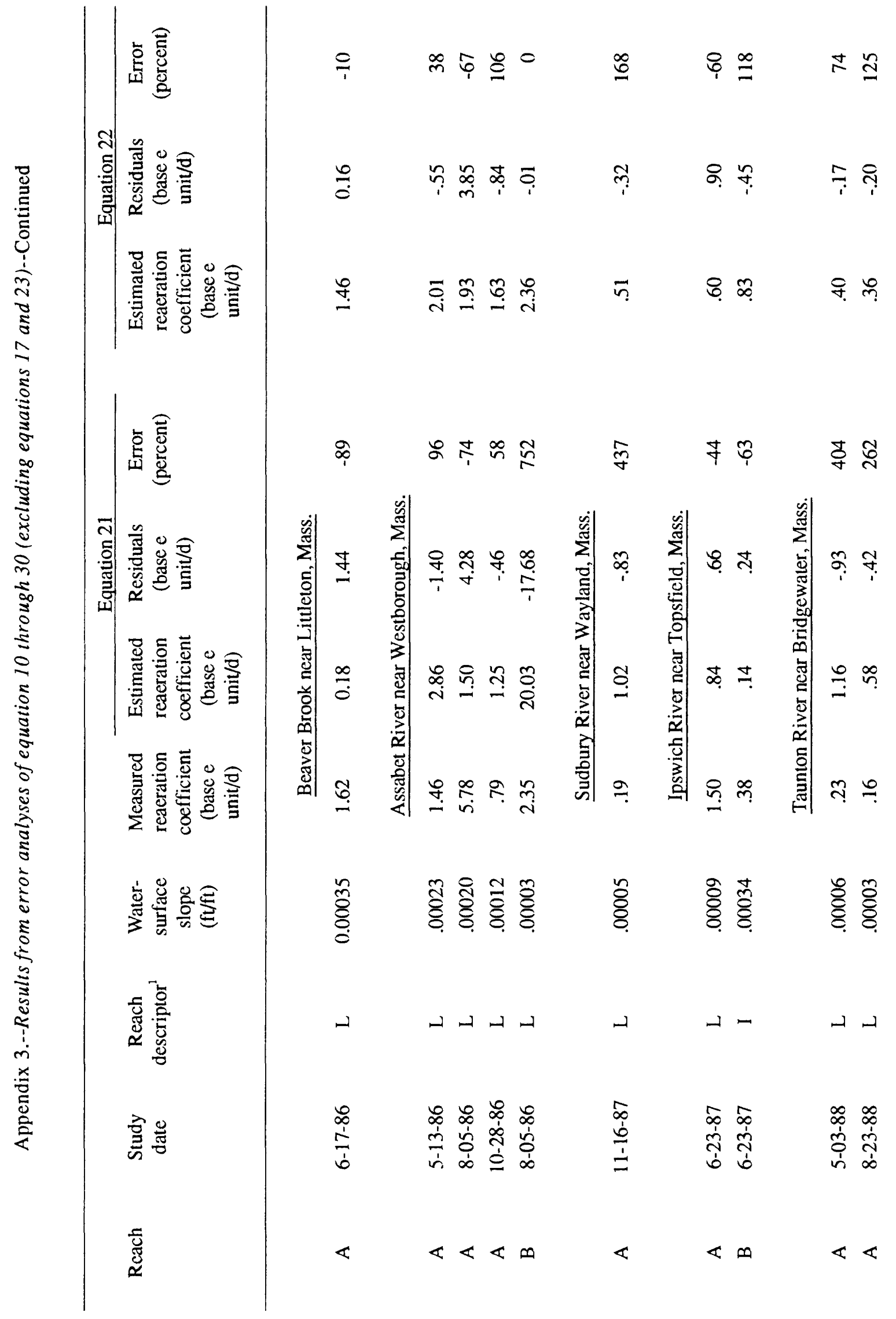




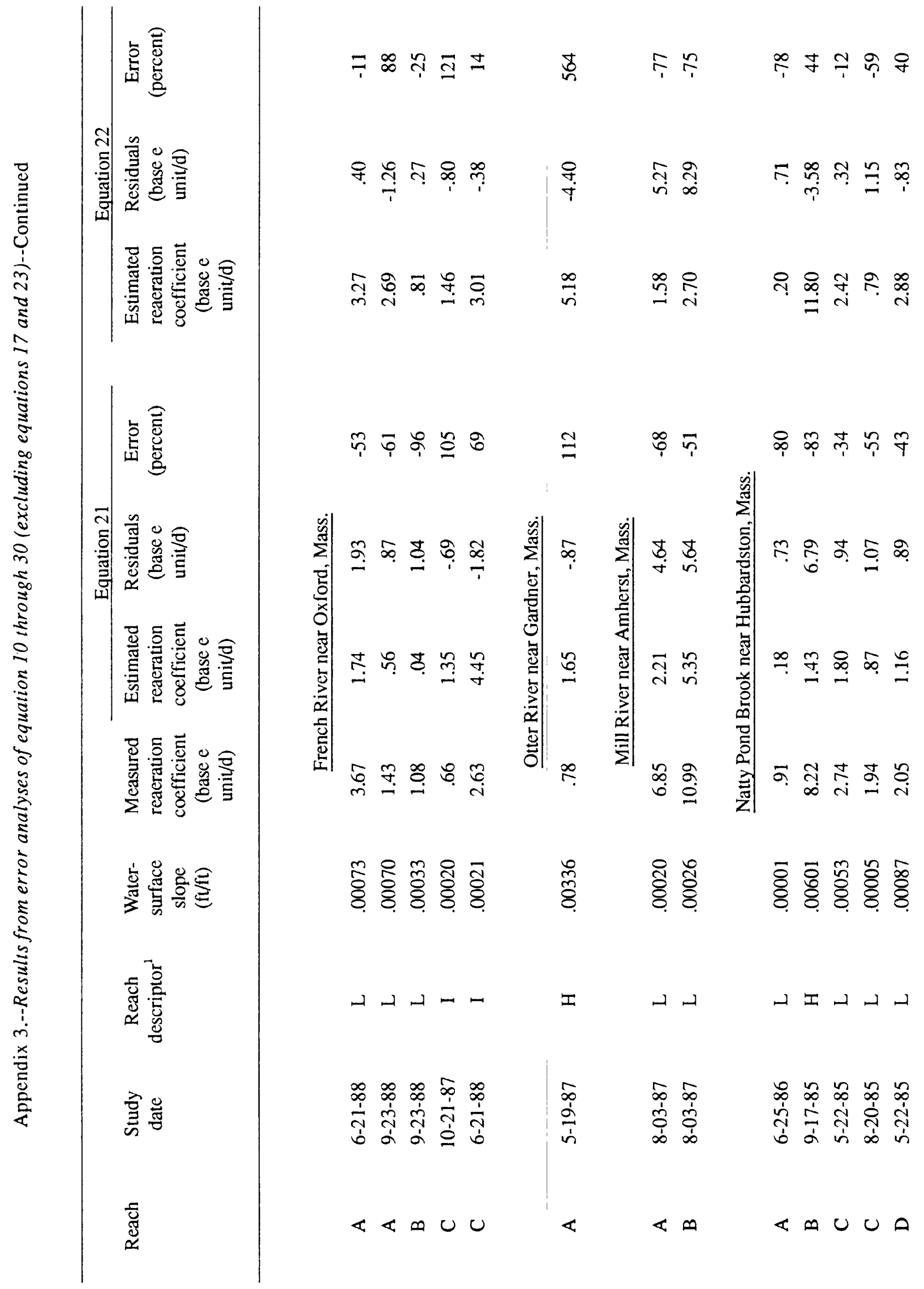




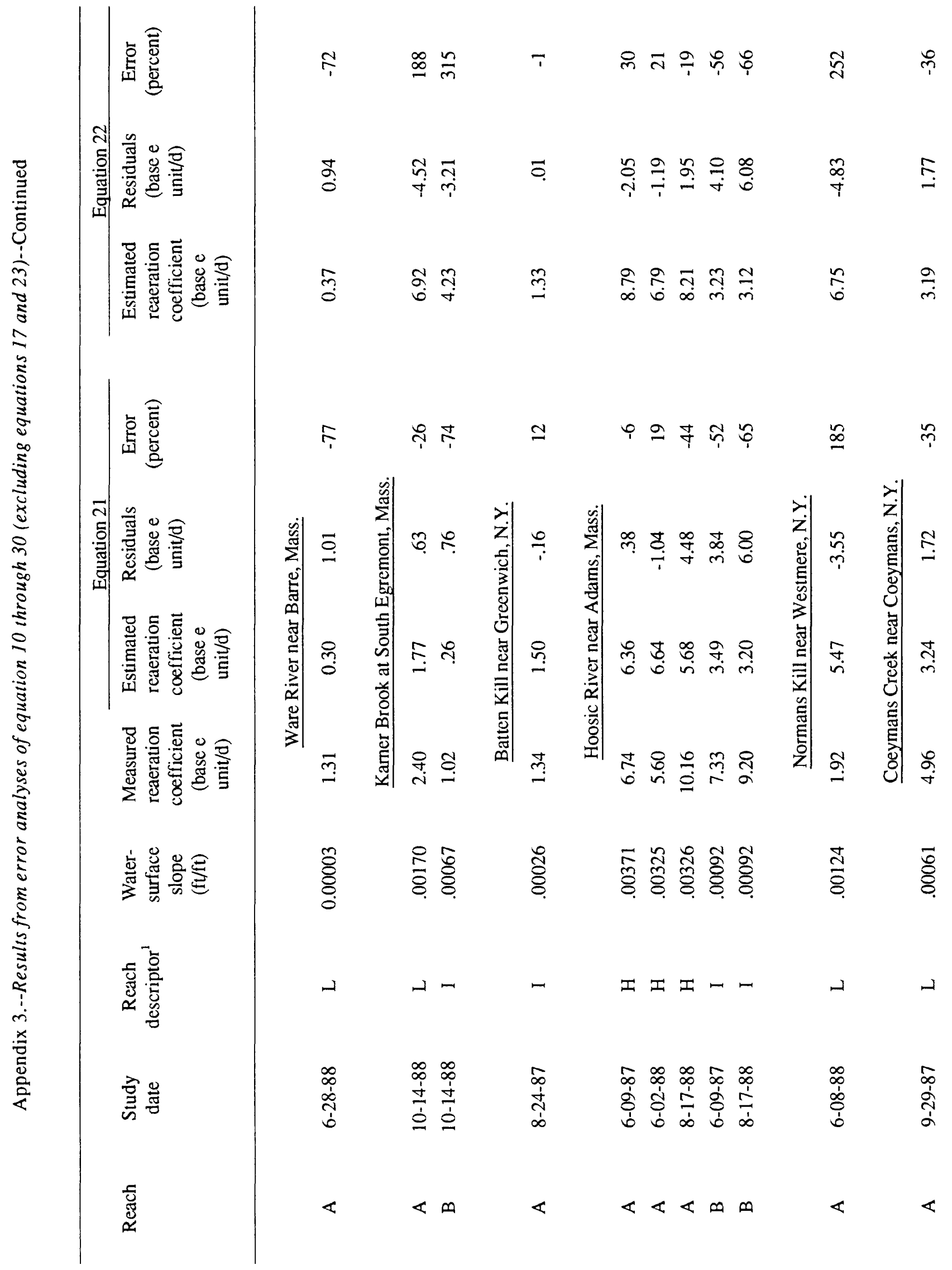




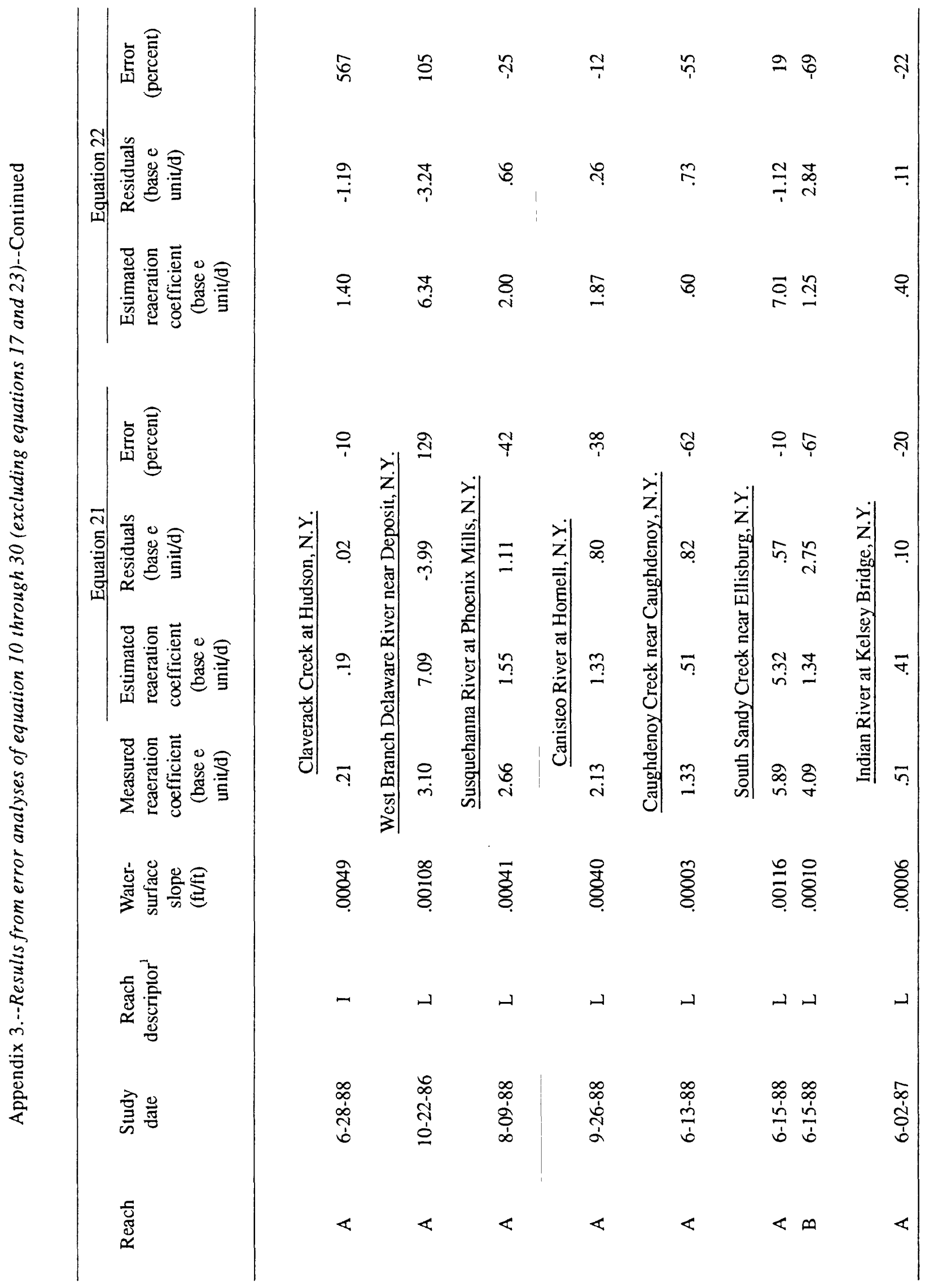




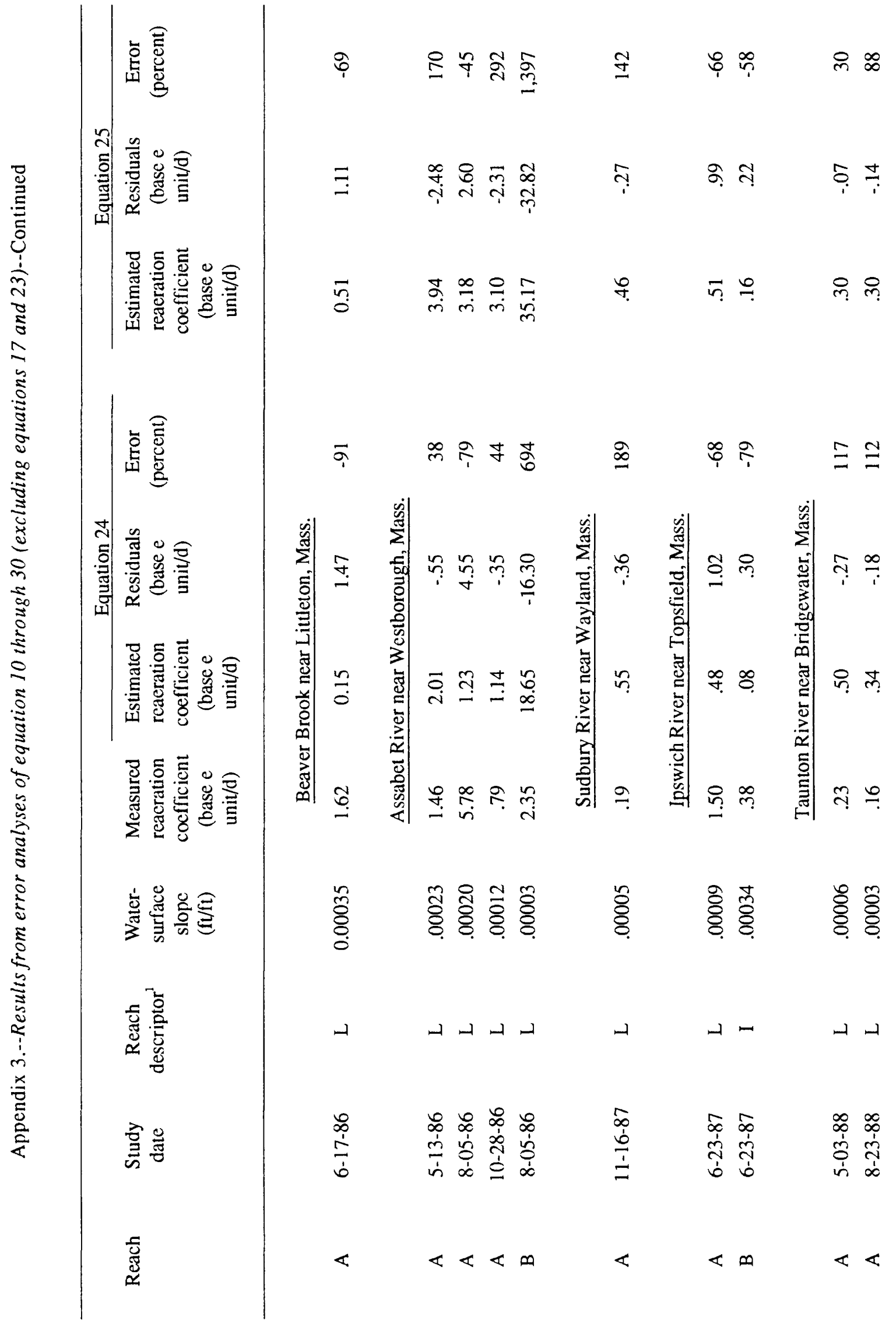




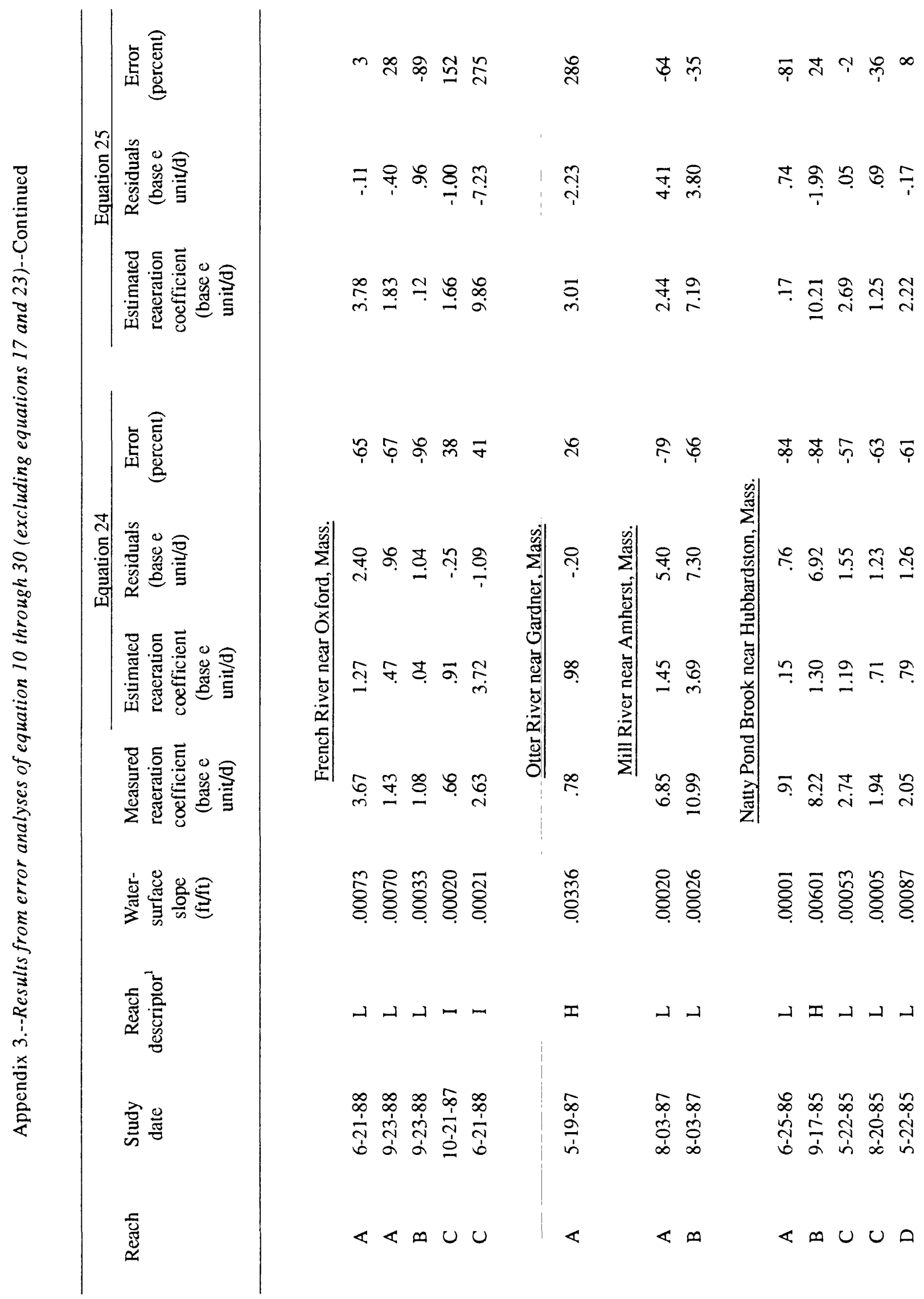




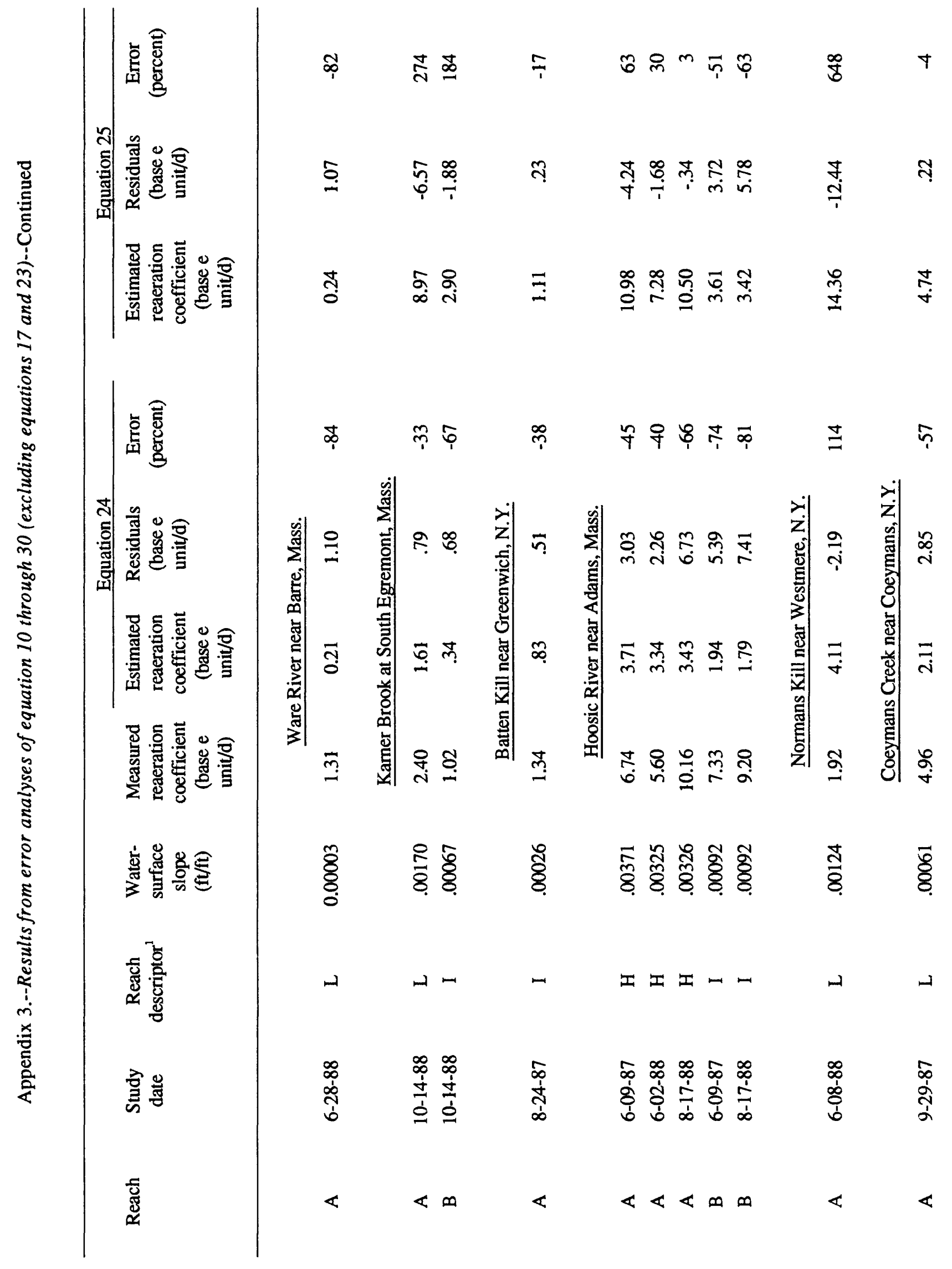




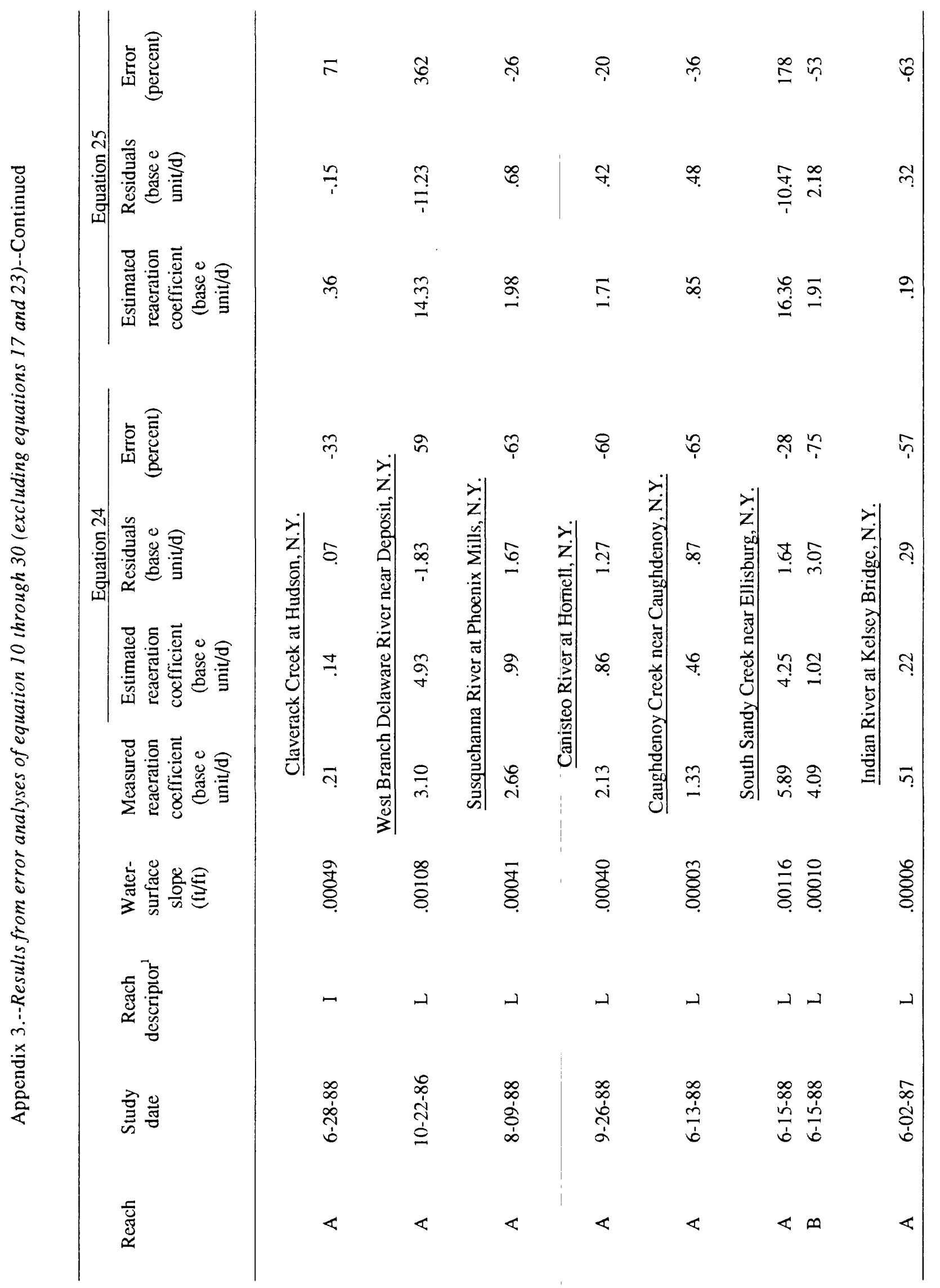




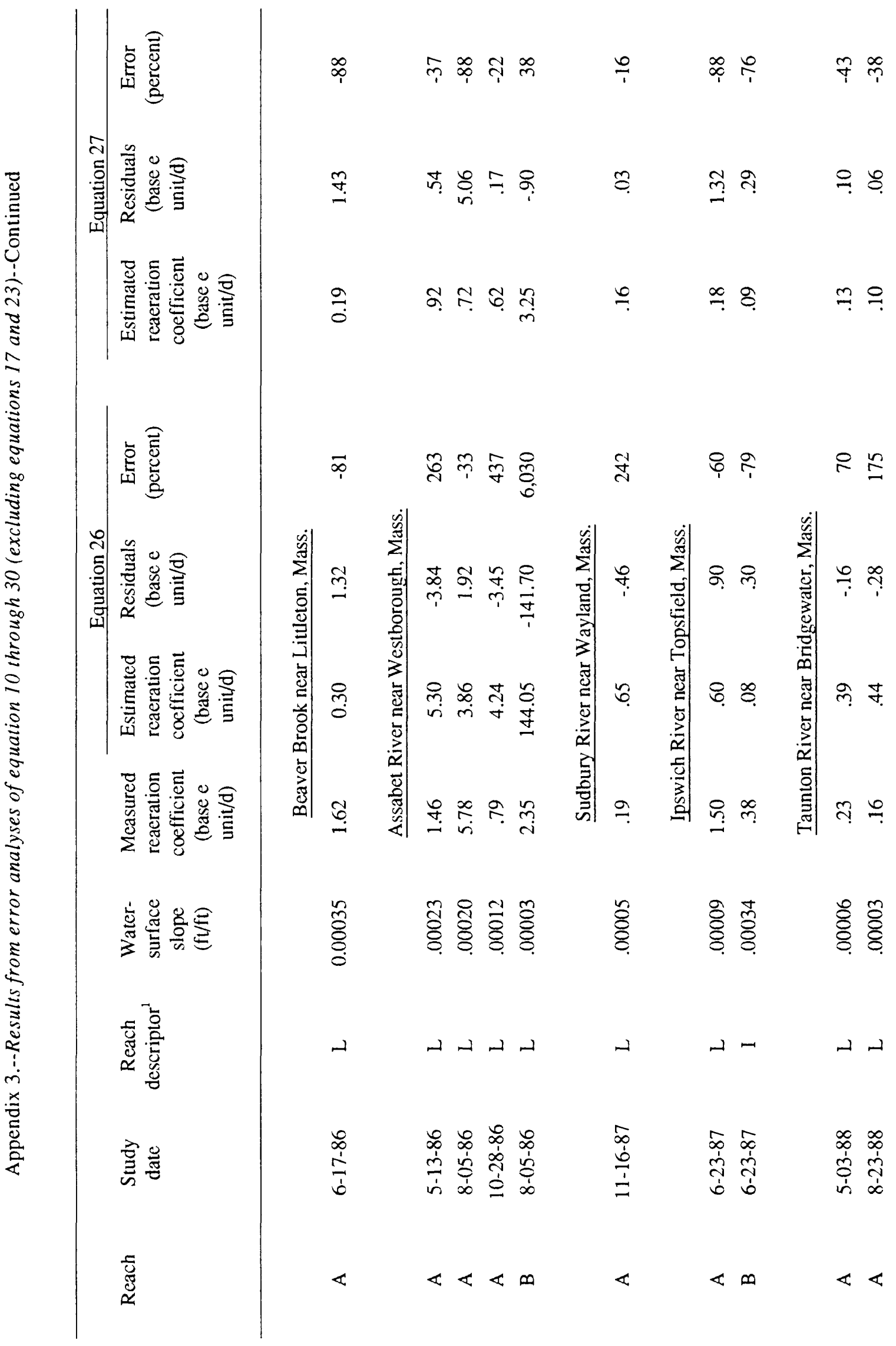




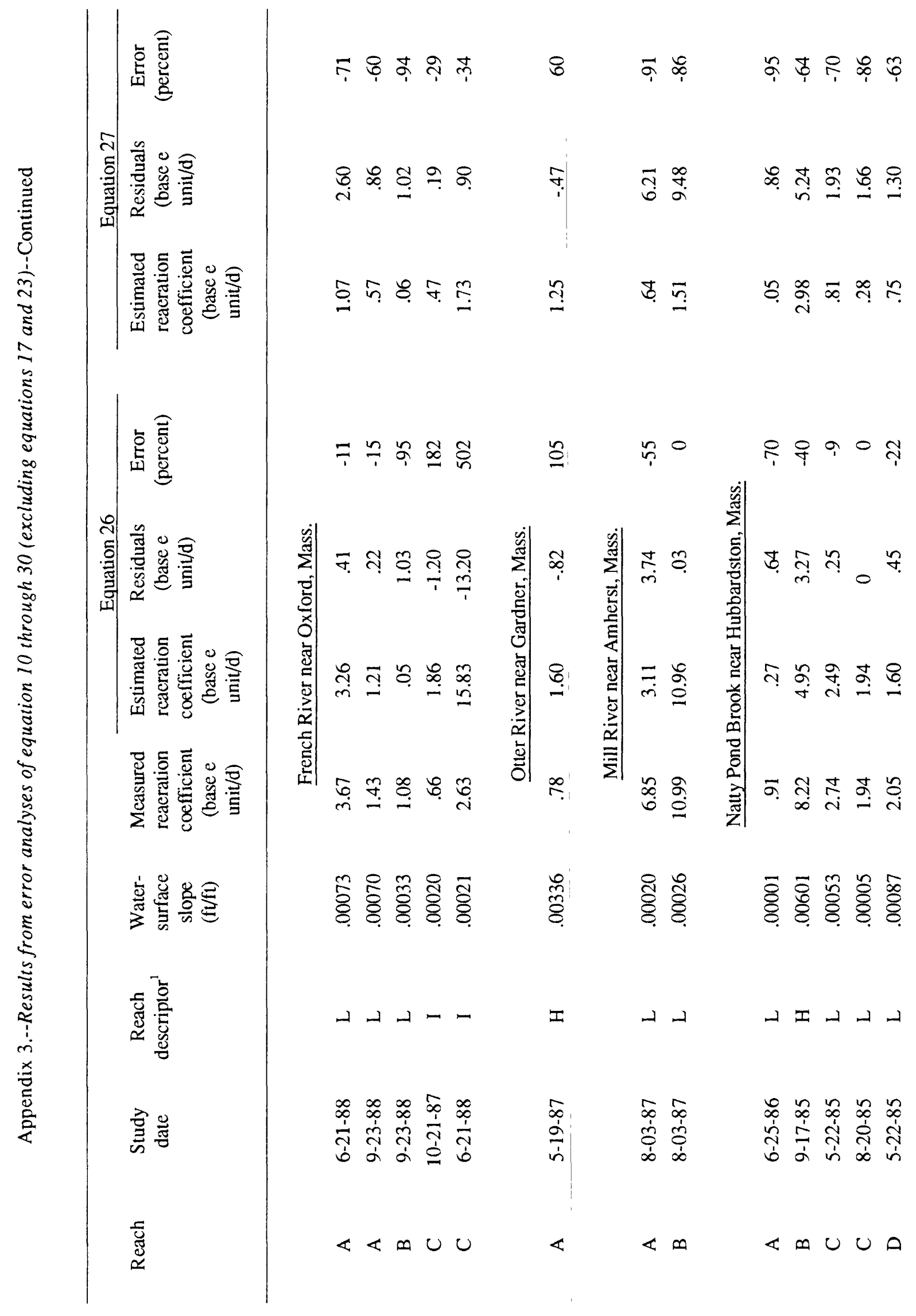




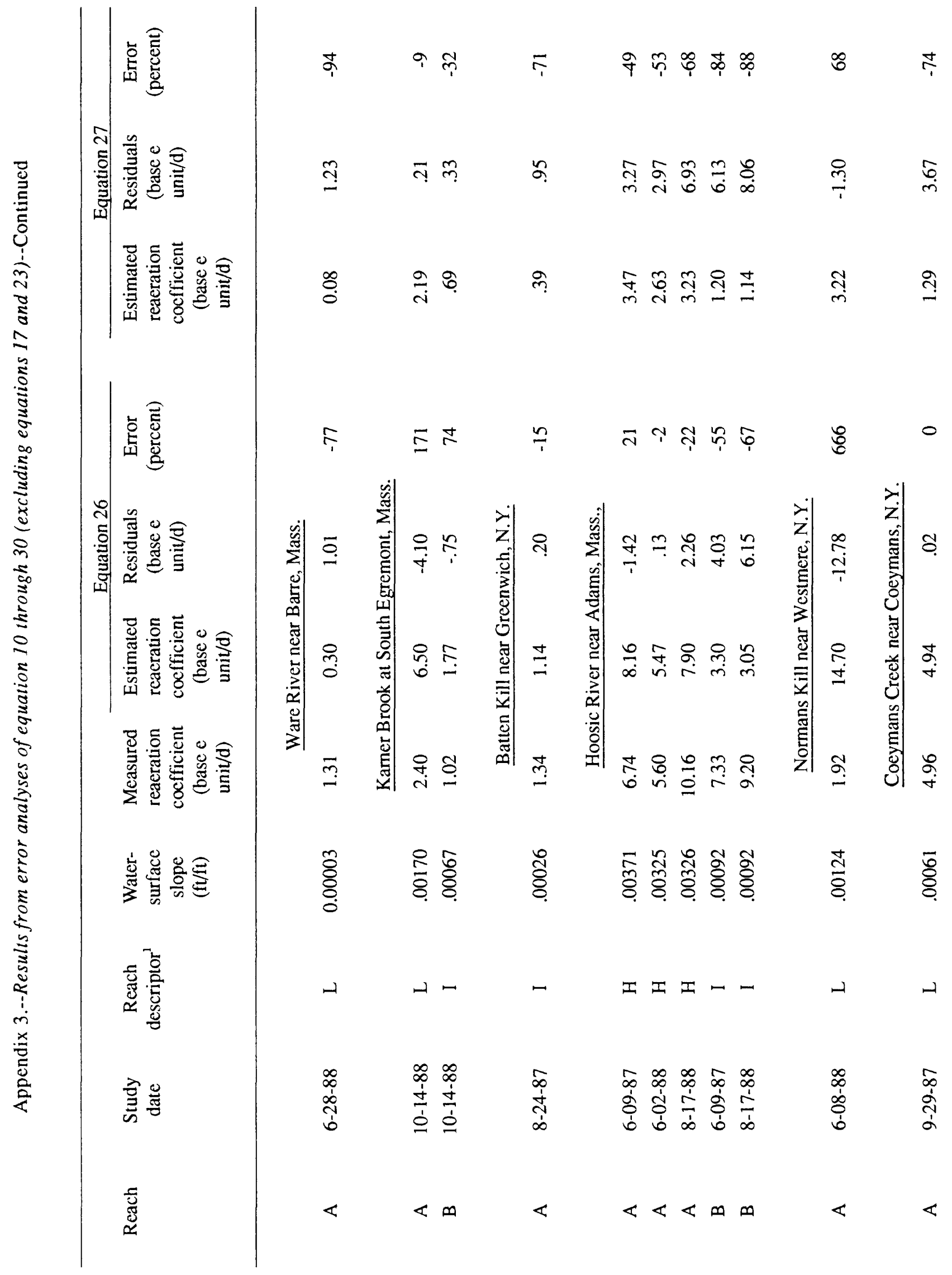




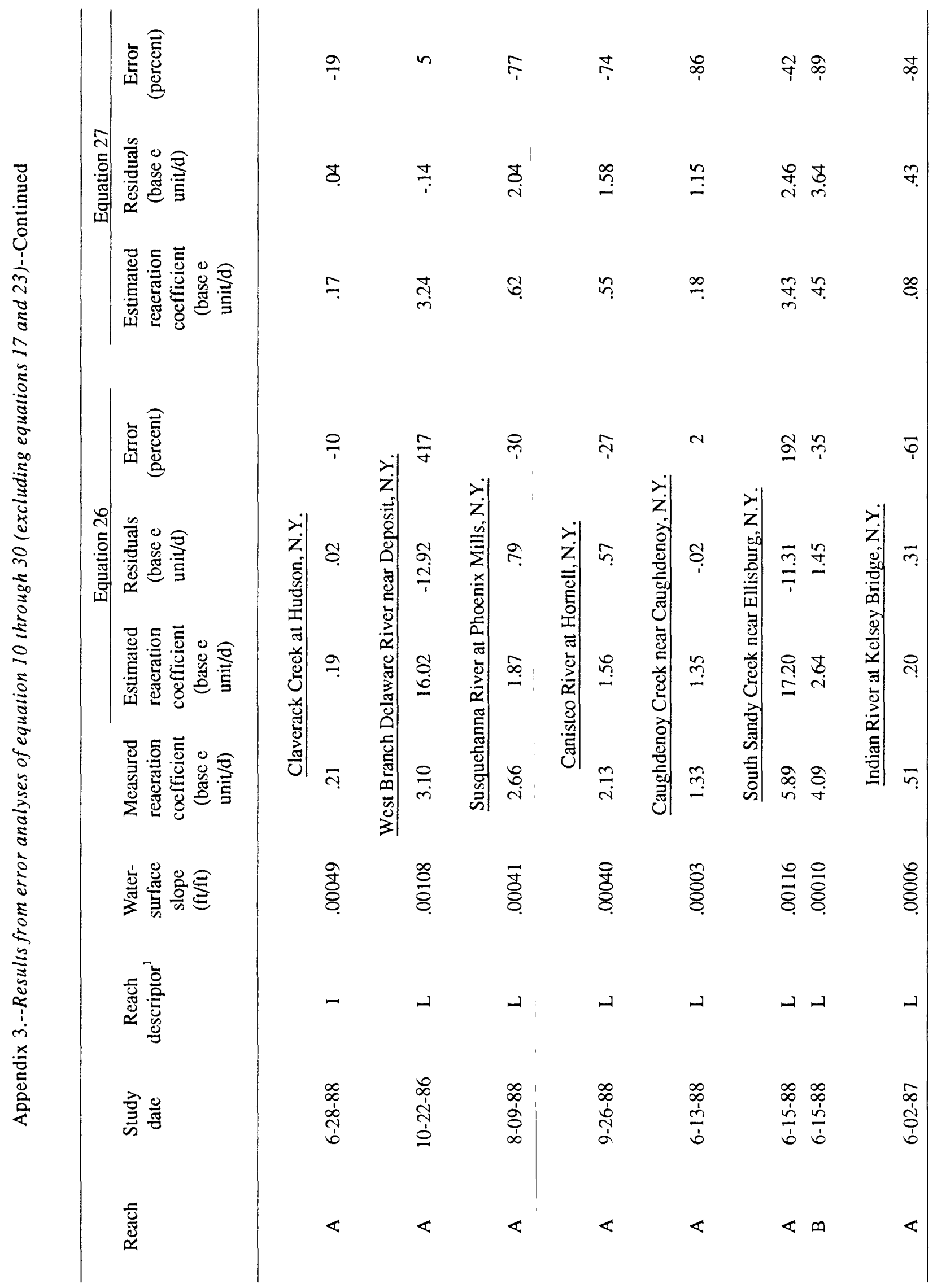




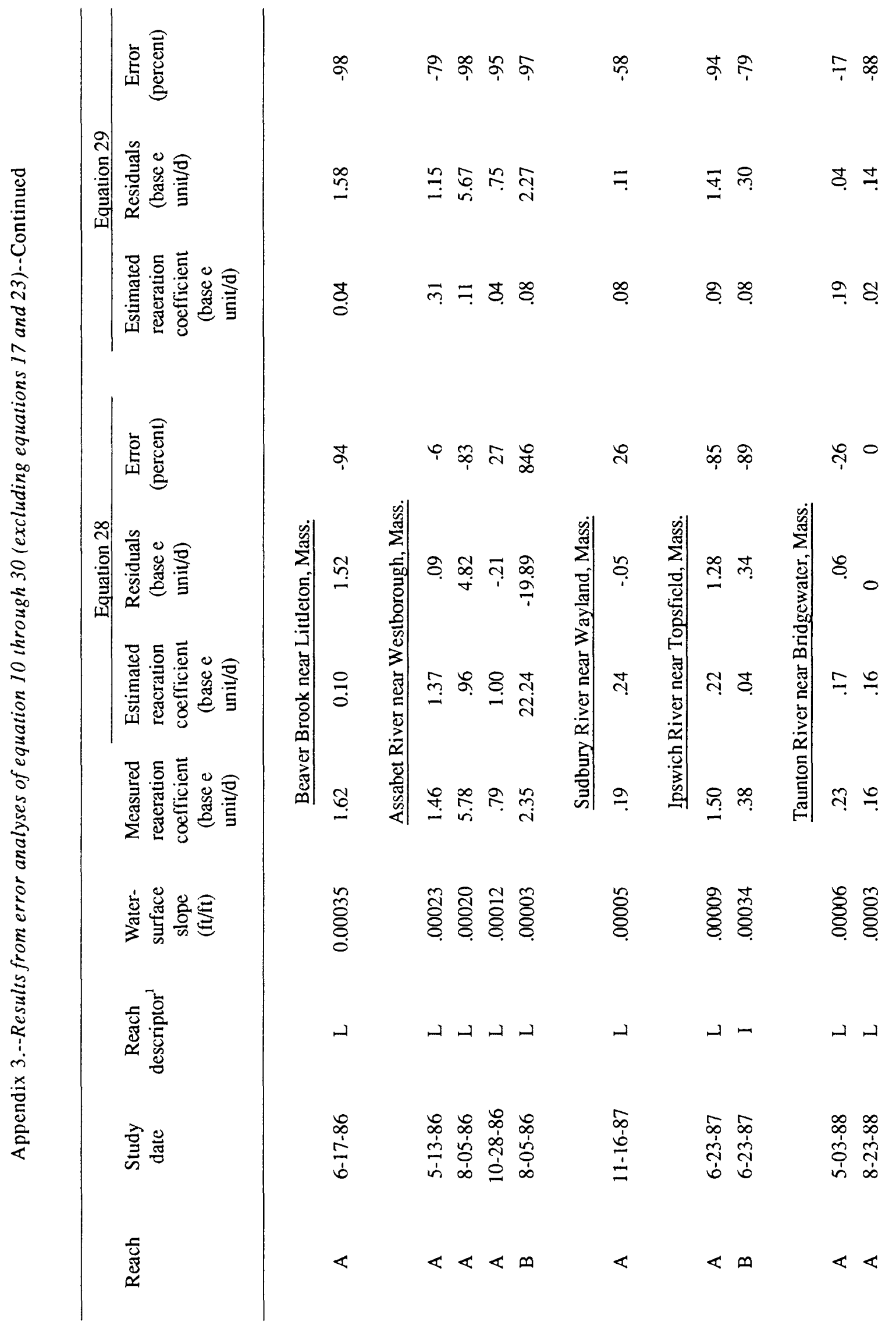




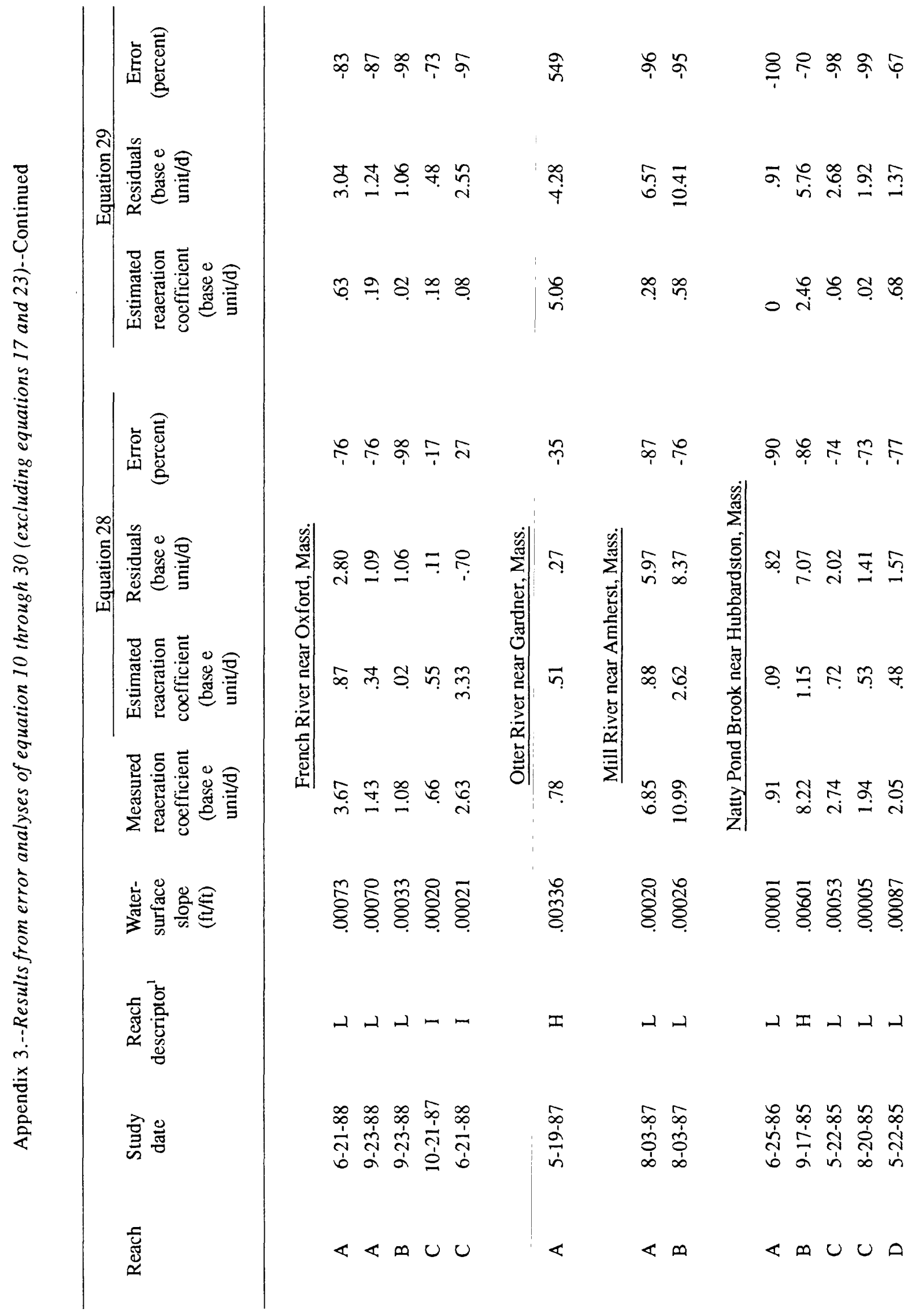




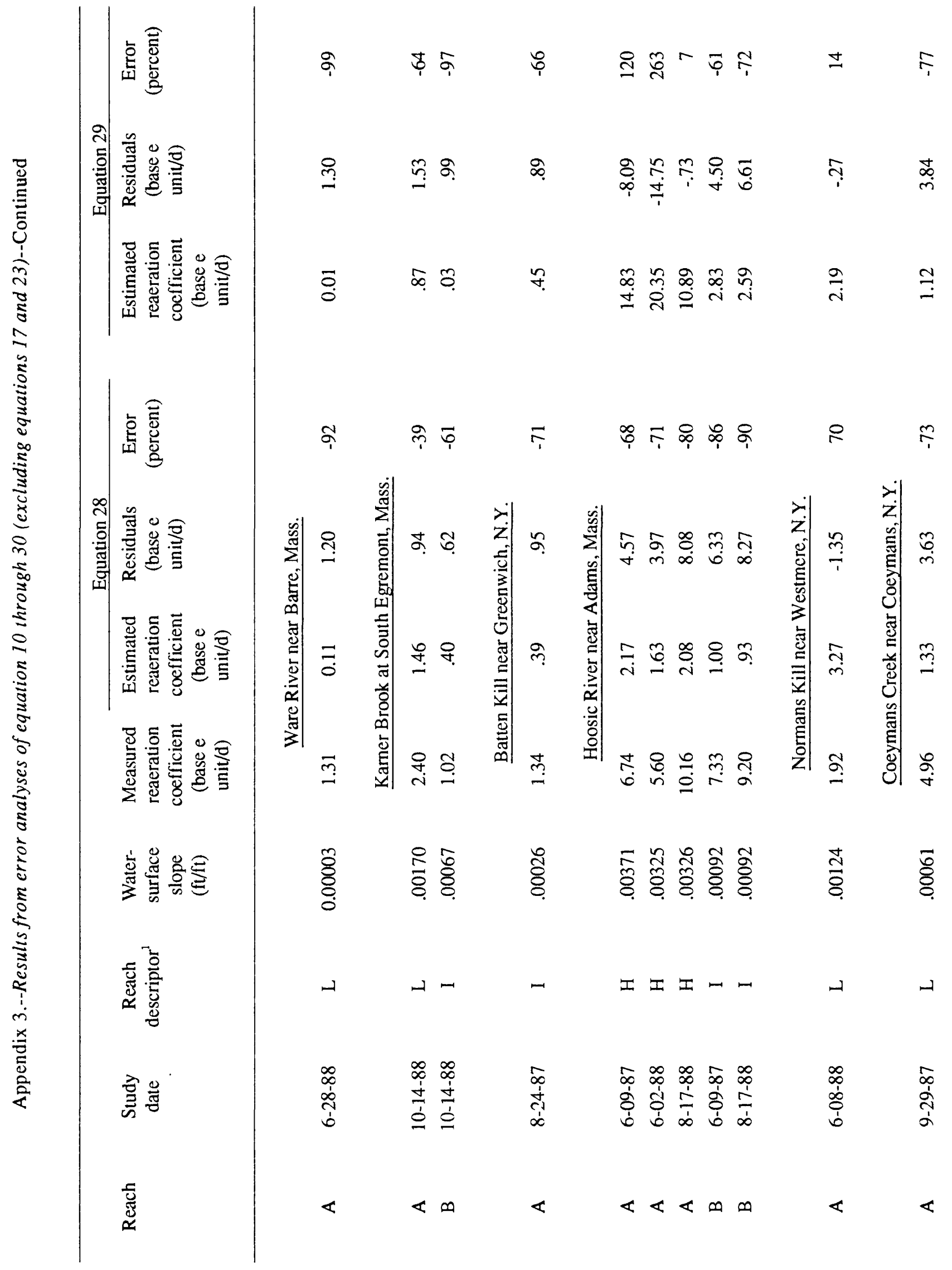




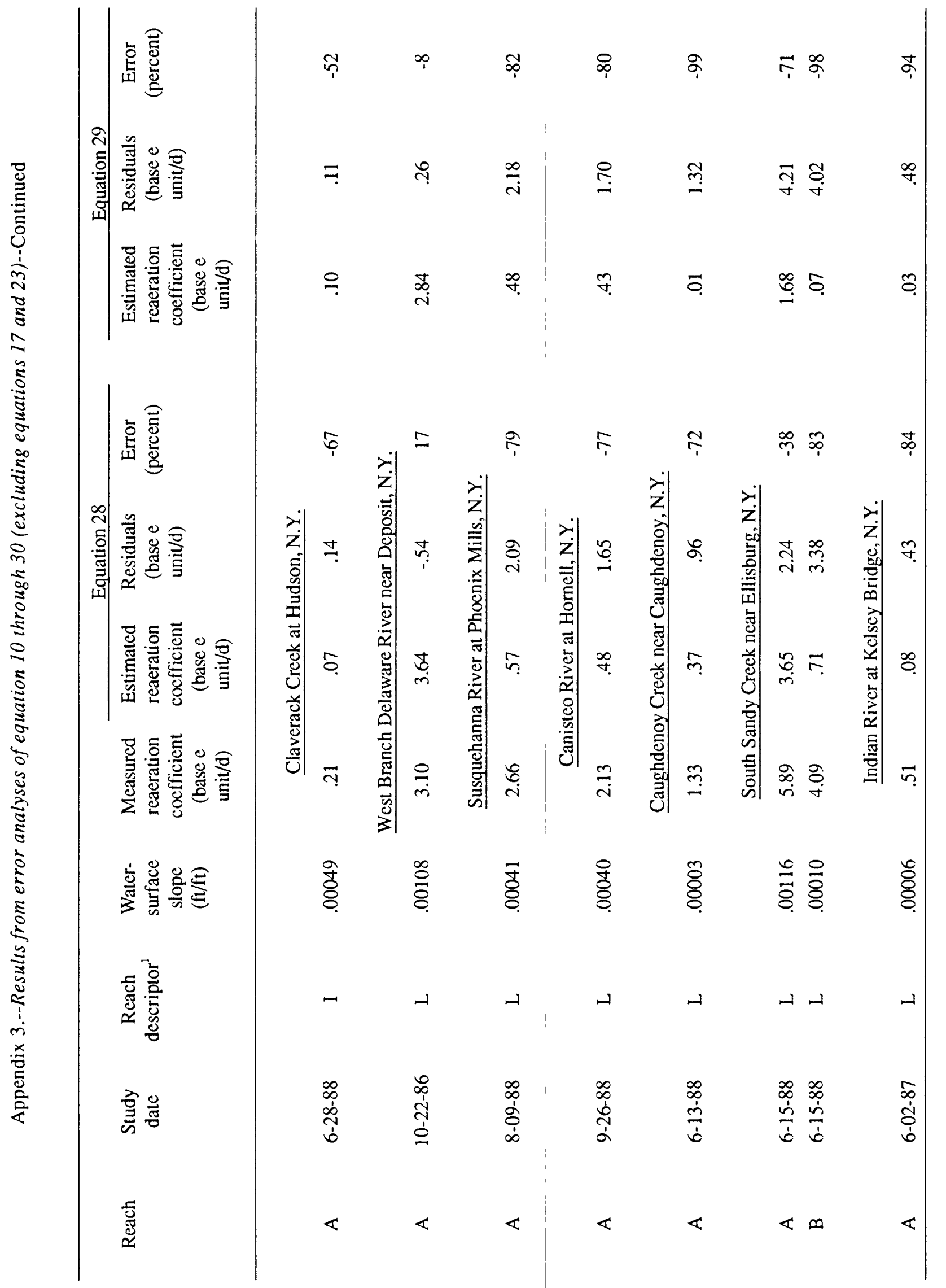




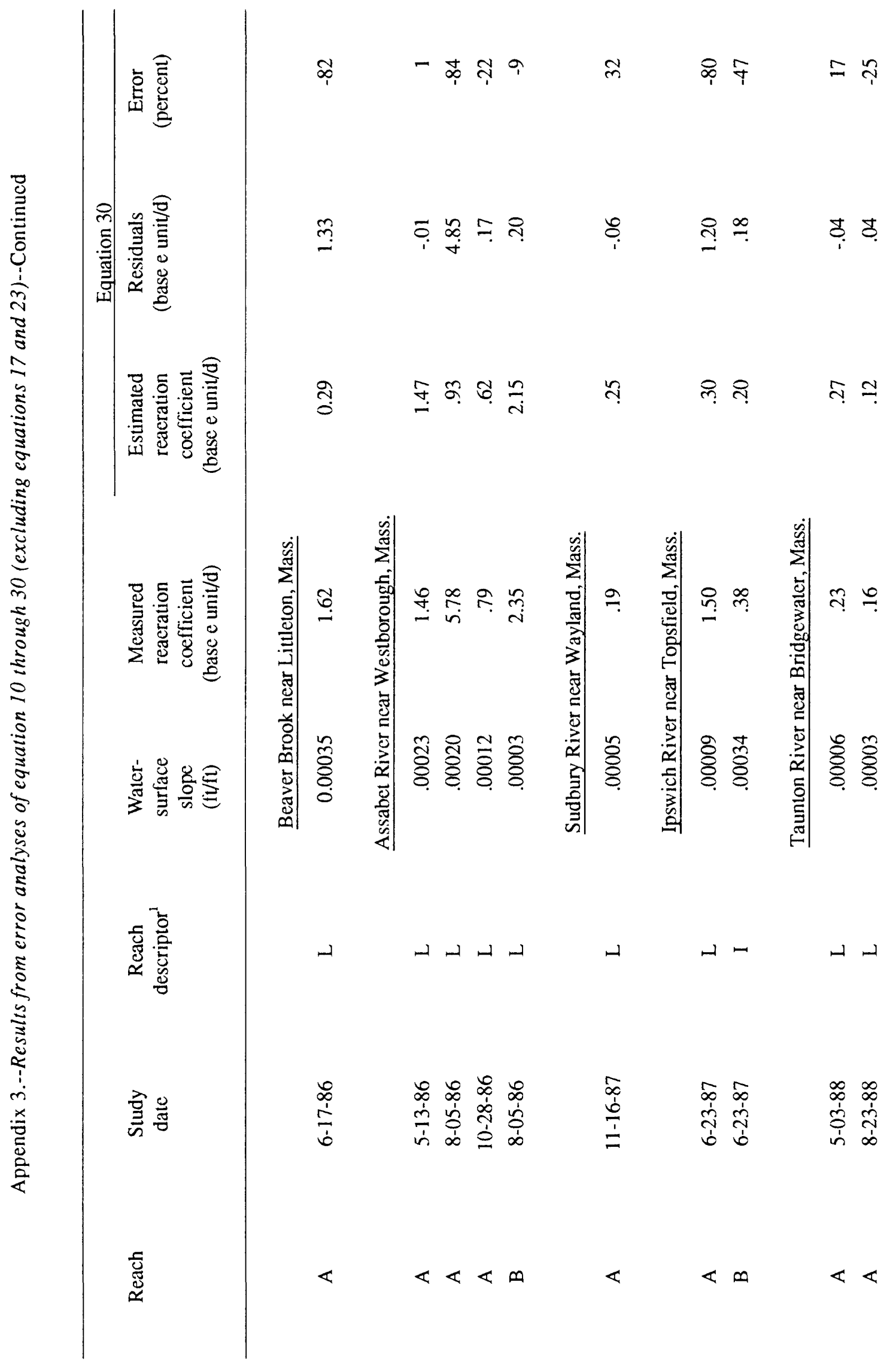




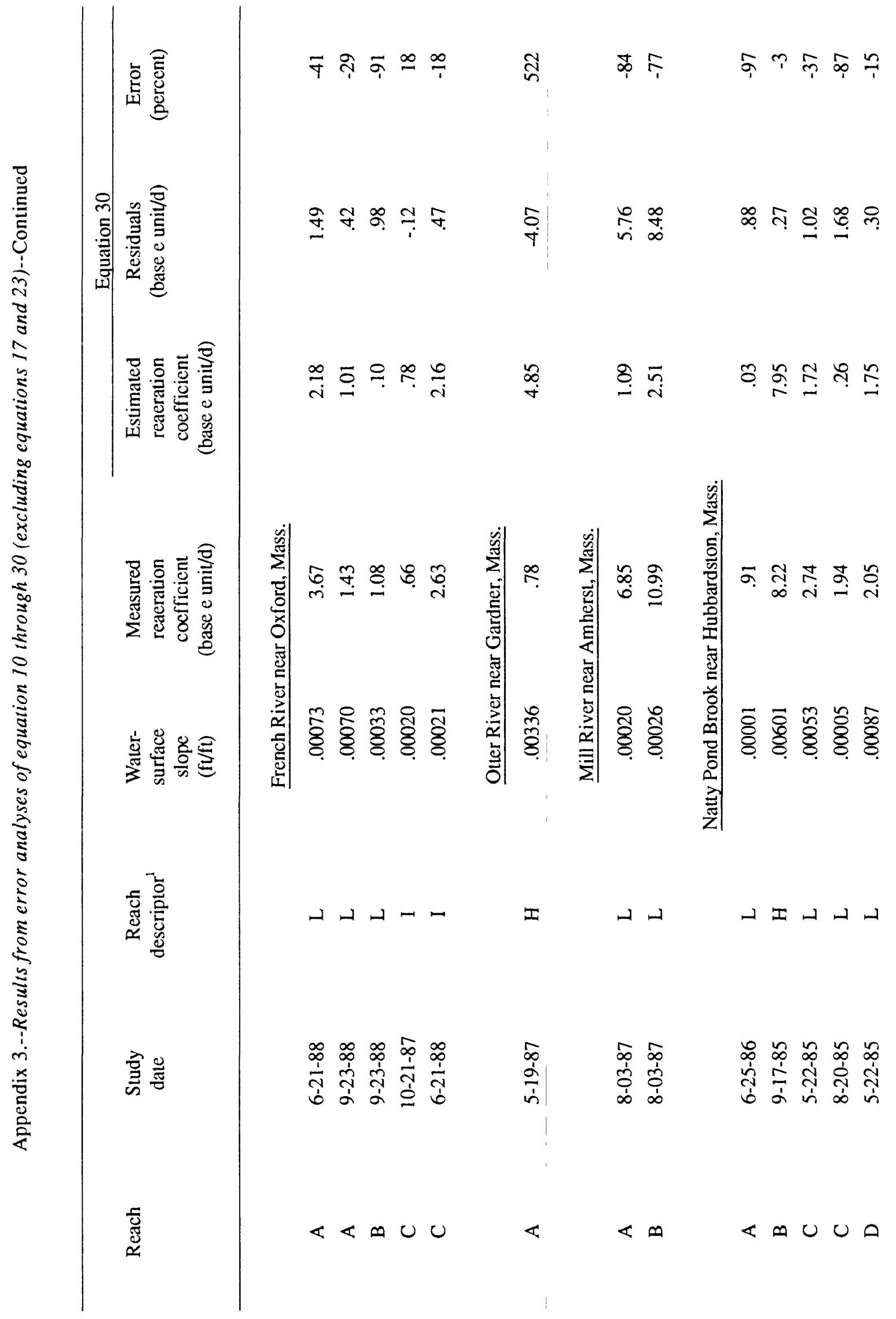




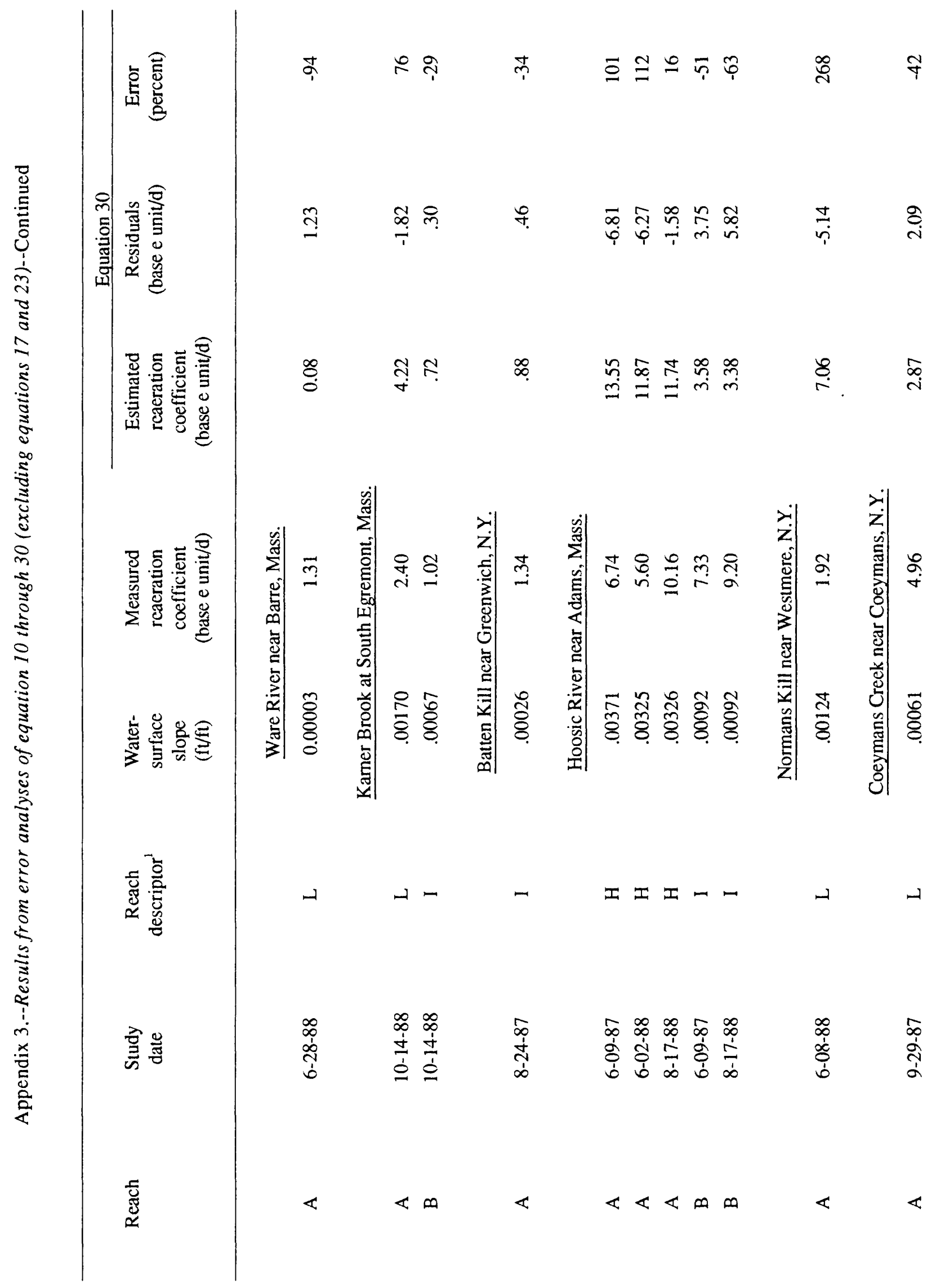




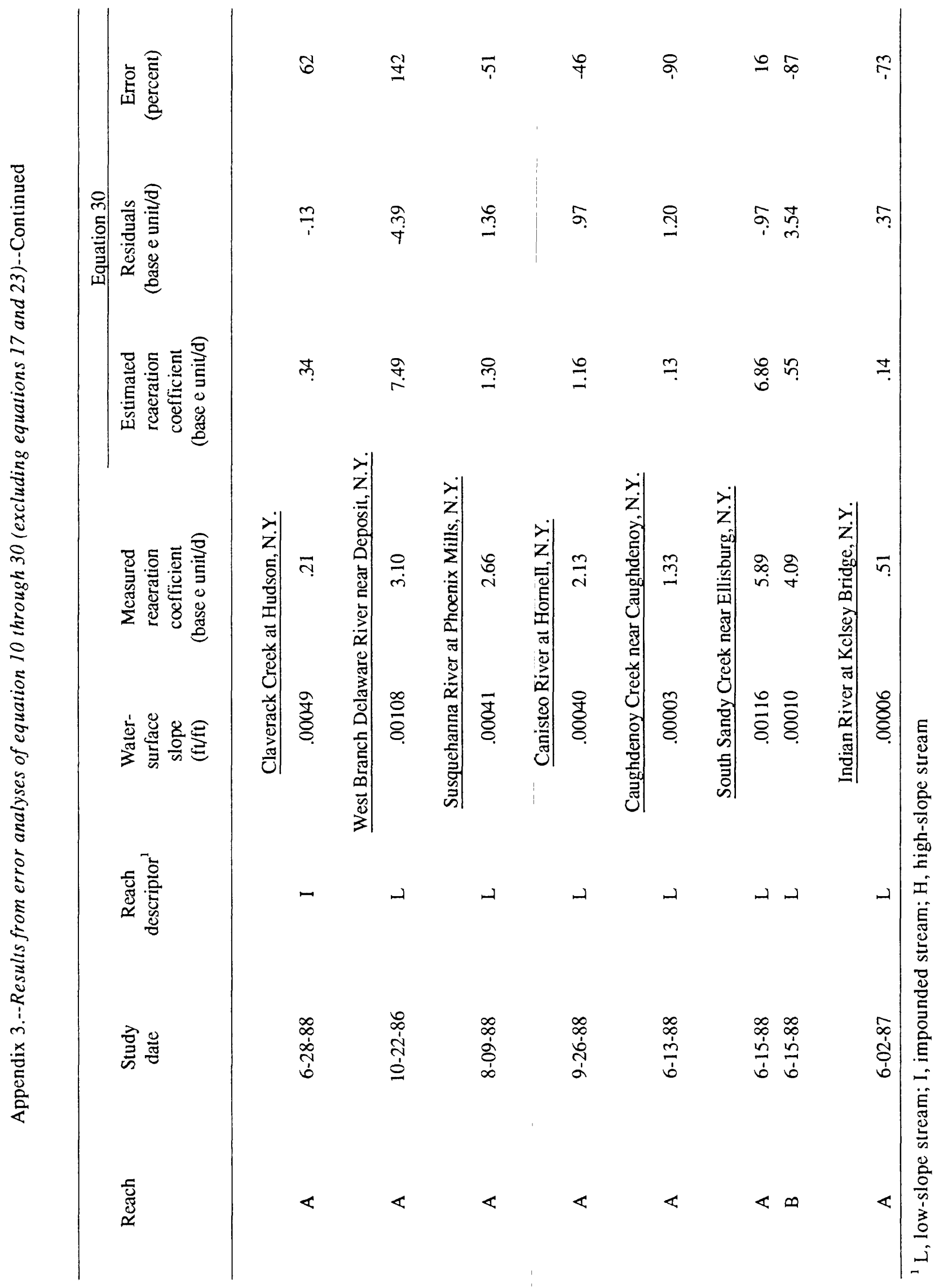


Appendix 4.--Results from error analysis of new empirical equation

[ft/ft, foot per foot; d, day]

\begin{tabular}{|c|c|c|c|c|c|c|c|}
\hline Reach & $\begin{array}{l}\text { Study } \\
\text { date }\end{array}$ & $\begin{array}{c}\text { Reach } \\
\text { descriptor }^{1}\end{array}$ & $\begin{array}{c}\text { Water-surface } \\
\text { slope } \\
(\mathrm{f} t / \mathrm{ft})\end{array}$ & $\begin{array}{l}\text { Measured } \\
\text { reaeration } \\
\text { coefficient } \\
\text { (base e unit/d) }\end{array}$ & $\begin{array}{c}\text { Estimated } \\
\text { reaeration } \\
\text { coefficient } \\
\text { (base e unit/d) }\end{array}$ & $\begin{array}{c}\text { Residuals } \\
\text { (base e unit/d) }\end{array}$ & $\begin{array}{c}\text { Error } \\
\text { (percent) }\end{array}$ \\
\hline
\end{tabular}

Beaver Brook near Lituleton, Mass.
A $\quad 6-17-86$
L
$0.00035 \quad 1.62$
0.94
$0.68 \quad-42$

Assabet River near Westborough. Mass.

$\begin{array}{lrllllll}\text { A } & 5-13-86 & \text { L } & .00023 & 1.46 & 1.27 & .19 & -13 \\ \text { A } & 8-05-86 & \text { L } & .00020 & 5.78 & 1.42 & 4.36 & -75 \\ \text { A } & 10-28-86 & \text { L } & .00012 & .79 & 1.45 & -.66 & 84 \\ \text { B } & 8-05-86 & \text { L } & .00003 & 2.35 & 1.87 & .48 & -20\end{array}$

Sudbury River near Wayland. Mass.
A $\quad 11-16-87$
L
.00005
.19
.54
$-.35 \quad 184$

Ipswich River near Topsfield. Mass.

$\begin{array}{llllcccc}\text { A } & 6-23-87 & \text { L } & .00009 & 1.50 & .54 & .96 & -64 \\ \text { B } & 6-23-87 & \text { I } & .00034 & .38 & .44 & -.06 & 16\end{array}$

Taunton River near Bridgewater, Mass.

$\begin{array}{lrrrrrrr}\text { A } & 5-03-88 & \mathrm{~L} & .00006 & .23 & .25 & -.02 & 9 \\ \mathrm{~A} & 8-23-88 & \mathrm{~L} & .00003 & .16 & .32 & -.16 & 100\end{array}$


Appendix 4.--Results from error analysis of new empirical equation--Continued

\begin{tabular}{|c|c|c|c|c|c|c|c|}
\hline Reach & $\begin{array}{l}\text { Study } \\
\text { date }\end{array}$ & $\begin{array}{c}\text { Reach } \\
\text { descriptor }^{1}\end{array}$ & $\begin{array}{c}\text { Water-surface } \\
\text { slope } \\
(\mathrm{ft} / \mathrm{ft})\end{array}$ & $\begin{array}{l}\text { Measured } \\
\text { reaeration } \\
\text { coefficient } \\
\text { (base e unit/d) }\end{array}$ & $\begin{array}{c}\text { Estimated } \\
\text { reaeration } \\
\text { coefficient } \\
\text { (base e unit/d) }\end{array}$ & $\begin{array}{c}\text { Residuals } \\
\text { (base e unit/d) }\end{array}$ & $\begin{array}{c}\text { Error } \\
\text { (percent) }\end{array}$ \\
\hline
\end{tabular}

Erench River near Oxford. Mass.

$\begin{array}{lrrrrrrr}\text { A } & 6-21-88 & \text { L } & .00073 & 3.67 & 2.37 & 1.30 & -35 \\ \text { A } & 9-23-88 & \text { L } & .00070 & 1.43 & 2.08 & -.65 & 45 \\ \text { B } & 9-23-88 & \text { L } & .00033 & 1.08 & .66 & .42 & -39 \\ \text { C } & 10-21-87 & \text { I } & .00020 & .66 & 1.58 & -.92 & 139 \\ \text { C } & 6-21-88 & \text { I } & .00021 & 2.63 & 3.53 & -.90 & 34\end{array}$

Mill River near Amherst. Mass.

$\begin{array}{llllllll}\text { A } & 8-03-87 & \text { L } & .00020 & 6.85 & 1.33 & 5.52 & -81 \\ \text { B } & 8-03-87 & \text { L } & .00026 & 10.99 & 2.19 & 8.80 & -80\end{array}$

Natty Pond Brook near Hubbardston. Mass.

$\begin{array}{rrrrrrrrr}\text { A } & 6-25-86 & \text { L } & .00001 & .91 & .49 & .42 & -46 \\ \text { C } & 5-22-85 & \text { L } & .00053 & 2.74 & 1.65 & 1.09 & -40 \\ \text { C } & 8-20-85 & \text { L } & .00005 & 1.94 & 1.15 & .79 & -41 \\ \text { D } & 5-22-85 & \text { L } & .00087 & 2.05 & 1.67 & .38 & -19\end{array}$


Appendix 4.--Results from error analysis of new empirical equation--Continued

\begin{tabular}{|c|c|c|c|c|c|c|c|}
\hline Reach & $\begin{array}{l}\text { Study } \\
\text { date }\end{array}$ & $\begin{array}{c}\text { Reach } \\
\text { descriptor }^{1}\end{array}$ & $\begin{array}{c}\text { Water-surface } \\
\text { slope } \\
(\mathrm{ft} / \mathrm{ft})\end{array}$ & $\begin{array}{c}\text { Measured } \\
\text { reacration } \\
\text { coefficient } \\
\text { (base e unil/d) }\end{array}$ & $\begin{array}{c}\text { Estimated } \\
\text { reaeration } \\
\text { coefficient } \\
\text { (base e unit/d) }\end{array}$ & $\begin{array}{c}\text { Residuals } \\
\text { (base e unil/d) }\end{array}$ & $\begin{array}{c}\text { Error } \\
\text { (percent) }\end{array}$ \\
\hline
\end{tabular}

Ware River near Barre. Mass.
A
$6-28-88$
$\mathrm{L}$
0.00003
1.31
0.57
$0.74 \quad-56$

Karner Brook at South Egremont, Mass.

$\begin{array}{llllllll}\text { A } & 10-14-88 & \text { L } & .00170 & 2.40 & 6.03 & -3.63 & 151 \\ \text { B } & 10-14-88 & \text { I } & .00067 & 1.02 & 5.22 & -4.20 & 412\end{array}$

Batten Kill near Greenwich. N.Y.

$\begin{array}{llllllll}\text { A } & 8-24-87 & \text { I } & .00026 & 1.34 & 1.32 & .02 & -1\end{array}$

Hoosic River near Adams. Mass.

$\begin{array}{llllllll}\text { B } & 6-09-87 & \text { I } & .00092 & 7.33 & 1.99 & 5.34 & -73 \\ \text { B } & 8-17-88 & \text { I } & .00092 & 9.20 & 1.97 & 7.23 & -79\end{array}$

Normans Kill near Westmere, N.Y.
A
6-08-88
L $\quad .00124$
1.92
5.69
$-3.77 \quad 196$

Coeymans Creek near Coeymans, N.Y.
A $\quad 9-29-87$
L
.00061
4.96
2.98
$1.98 \quad-40$
Claverack Creek at Hudson, N.Y.

$\begin{array}{llllllll}\text { A } & 6-28-88 & \text { I } & .00049 & .21 & 1.19 & -.98 & 467\end{array}$


Appendix 4.--Results from error analysis of new empirical equation--Continued

\begin{tabular}{|c|c|c|c|c|c|c|c|}
\hline Reach & $\begin{array}{l}\text { Study } \\
\text { date }\end{array}$ & $\begin{array}{c}\text { Reach } \\
\text { descriptor }^{1}\end{array}$ & $\begin{array}{c}\text { Water-surface } \\
\text { slope } \\
(\mathrm{f} v / \mathrm{ft})\end{array}$ & $\begin{array}{l}\text { Measured } \\
\text { reacration } \\
\text { cocfficient } \\
\text { (base e unit/d) }\end{array}$ & $\begin{array}{c}\text { Estimated } \\
\text { reaeration } \\
\text { coefficient } \\
\text { (base e univ/d) }\end{array}$ & $\begin{array}{c}\text { Residuals } \\
\text { (base e unit/d) }\end{array}$ & $\begin{array}{c}\text { Error } \\
\text { (percent) }\end{array}$ \\
\hline \multicolumn{8}{|c|}{ West Branch Delaware River near Deposit. N.Y. } \\
\hline A & $10-22-86$ & $\mathrm{~L}$ & .00108 & 3.10 & 3.09 & .01 & 0 \\
\hline \multicolumn{8}{|c|}{ Susquehanna River at Phocnix Mills, N.Y. } \\
\hline $\mathrm{A}$ & $8-09-88$ & $\mathrm{~L}$ & .00041 & 2.66 & 2.02 & .64 & -24 \\
\hline \multicolumn{8}{|c|}{ Canisteo River at Hornell, N.Y. } \\
\hline A & $9-26-88$ & $\mathrm{~L}$ & .00040 & 2.13 & 1.91 & .22 & -10 \\
\hline \multicolumn{8}{|c|}{ Caughdenoy Creek near Caughdenoy, N.Y. } \\
\hline A & $6-13-88$ & $\mathrm{~L}$ & .00003 & 1.33 & 1.64 & -.31 & 23 \\
\hline \multicolumn{8}{|c|}{ South Sandy Creek near Ellisburg, N.Y. } \\
\hline $\mathrm{A}$ & $6-15-88$ & $\mathrm{~L}$ & .00116 & 5.89 & 6.36 & -.47 & 8 \\
\hline B & $6-15-88$ & $\mathrm{~L}$ & .00010 & 4.09 & 2.11 & 1.98 & -48 \\
\hline \multicolumn{8}{|c|}{ Indian River at Kelsey Bridge, N.Y. } \\
\hline $\mathrm{A}$ & $6-02-87$ & $\mathrm{~L}$ & .00006 & .51 & .56 & -.05 & 10 \\
\hline
\end{tabular}

${ }^{1} \mathrm{~L}$, low-slope stream; I, impounded stream 